Columbia Law School

Scholarship Archive

1994

\title{
Taking Subsidiarity Seriously: Federalism in the European Community and the United States
}

George A. Bermann

Columbia Law School, gbermann@law.columbia.edu

Follow this and additional works at: https://scholarship.law.columbia.edu/faculty_scholarship

Part of the Comparative and Foreign Law Commons, and the European Law Commons

\section{Recommended Citation}

George A. Bermann, Taking Subsidiarity Seriously: Federalism in the European Community and the United States, 94 CoLUM. L. ReV 331 (1994).

Available at: https://scholarship.law.columbia.edu/faculty_scholarship/6

This Article is brought to you for free and open access by the Faculty Publications at Scholarship Archive. It has been accepted for inclusion in Faculty Scholarship by an authorized administrator of Scholarship Archive. For more information, please contact scholarshiparchive@law.columbia.edu. 


\title{
COLUMBIA LAW REVIEW
}

VOL. 94

MARCH 1994

NO. 2

\section{TAKING SUBSIDIARITY SERIOUSLY: FEDERALISM IN THE EUROPEAN COMMUNITY AND THE UNITED STATES}

\author{
George A. Bermann* \\ TABle of Contents
}

Introduction ....................................... 332

I. Subsidiarity and the European Community ............ 338

A. Toward Clarity about Subsidiarity ................ 339

1. Self-determination and Accountability ........... 340

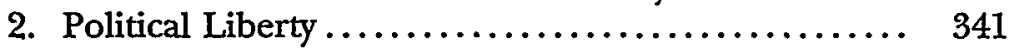

3. Flexibility $\ldots \ldots \ldots \ldots \ldots \ldots \ldots \ldots \ldots \ldots \ldots \ldots \ldots, 341$

4. Preservation of Identities .................... 341

5. Diversity .............................. 341

6. Respect for Internal Divisions of Component States . 342

B. Subsidiarity and the European Community Treaties .... 344

C. Subsidiarity and the Evolution of Community

Federalism .................................. 348

1. The Court of Justice and its Supranationalist

Creation ................................. 348

2. New Elements in Community Federalism ......... 354

a. Widening the Community Terrain ........... 354

i. The Enumeration of Community Powers .... 355

ii. Preemption of Member State Law......... $\quad 357$

iii. The Elasticity of Community Powers ....... 361

b. The Community's New Institutional Dynamics... 362

c. The Maastricht Environment................. 365

II. Putting Subsidiarity into Practice ................. 366

A. The European Council Guidelines ................ 368

B. Subsidiarity in the Community Tradition............ 371

C. Subsidiarity as a Mode of Legislative Analysis......... 378

1. Institutional Aspects of Subsidiarity ........... 379

2. Distinguishing Policy Measures and Harmonization

Measures ................................ 383

3. Subsidiarity and Proportionality .............. 386

D. Subsidiarity and the Court of Justice ............. 390

1. Subsidiarity as a Procedural and Substantive Norm . 391

* Charles Keller Beekman Professor of Law, Columbia University School of Law. The research assistance of Hoyt P. Webb, J.D./M.B.A. 1993, Columbia University, is gratefully acknowledged. 
2. The Strength of the Political Safeguards of Subsidiarity

3. Subsidiarity and the Direct Effect of the EC Treaty.

III. Subsidiarity and U.S. Federalism.................... 403

A. Subsidiarity in the U.S. Institutional Context ........ 403

B. Congress and Subsidiarity .................... 407

C. Constitutional Constraints ...................... 416

D. Subsidiarity and the Judicial Function ............ 423

1. Subsidiarity as an Enforceable Legislative Norm .... 424

2. Preemption and Frustration of Congressional Purpose ................................ 424

E. Subsidiarity and the Agencies .................. 427

1. Subsidiarity as a Legislative Command to the Agencies

2. Agency Authority to Preempt State Law ......... 429

3. Agency Self-Limitation..$\ldots \ldots \ldots \ldots \ldots \ldots \ldots \ldots .430$

4. Presidential Restraints on Federal Regulation ....... 436

a. Executive Order 12,291 and Proportionality .... 437

b. Executive Order 12,372 and Federalism ........ 439

c. Executive Order 12,612 and Subsidiarity ....... 440

d. The Executive Orders in Practice ............ 442

e. Clinton Executive Order 12,866 on Regulatory Review ................................. 445

F. Conclusion ............................... 447

IV. EG Subsidiarity and U.S. Federalism ................ 448

A. The U.S. and EC Settings..................... 449

B. Subsidiarity and U.S. Federalism Revisited ......... 450

C. The Political Safeguards of Federalism and "Commandeering" in the Community............... 453

D. Conclusion ............................. 455

\section{INTRODUCTION}

For a principle that has dominated discussions of European federalism for over five years, subsidiarity has received surprisingly poor academic mention. Subsidiarity has been criticized as "inelegant... 
Eurospeak,"1 "the epitome of confusion,"2 and simple "gobbledegook."3 It has been described by some as nothing new ${ }^{4}$ and by others as quite novel and actually quite dangerous. ${ }^{5}$ The President of the Commission of the European Communities, said to be an enthusiast of subsidiarity, finds it used at times as an "alibi," 6 and more specifically as "a fig leaf ... to conceal [an] unwillingness to honour the commitments which have already been endorsed." Despite subsidiarity's apparent difficulties, the

1. Graham P. Smith, Subsidiarity and Article 9, 1992 Int'l Merger Law: Events and Commentary (no. 24); see also Lord Mackenzie-Stuart, A Formula for Failure, The Times (London), Dec. 11, 1992, at 18 (Lord Mackenzie-Stuart was President of the Court of Justice of the European Communities from 1984 to 1988). Subsidiarity has been called by one European academic "basically an empty shell devoid of concrete substance." Guenther F. Schaefer, Institutional Choices: The Rise and Fall of Subsidiarity, 23 Futures 681,688 (1991). Others agree. See Daniela Obradovic, Community Law and the Doctrine of Divisible Sovereignty, 1 Legal Issues of Eur. Integration 1, 14-17 (1993).

2. Editorial Comment, Subsidiarity: Furthering the Confusion, 5 Europe 2000Executive Review (June 1992); see also Andrew Adonis \& Andrew Tyrie, Subsidiarity: No Panacea (1992) (arguing that subsidiarity is fundamentally incapable of playing the role Maastricht's authors envision); Les Metcalfe, Redesigning Europe, Paper Delivered at Third Biennial International Conference of the European Community Studies Association, Washington, D.C. (May 27-29, 1993) (on file with the Columbia Law Review) (the meaning of subsidiarity varies with the model of public management employed).

For a somewhat more favorable description, see Dominik Lasok, Subsidiarity and the Occupied Field, 142 New L.J. 1228, 1228 (1992) (subsidiarity is "vague but not unintelligible"). For other basically positive assessments of subsidiarity, see generally Deborah Z. Cass, The Word That Saves Maastricht? The Principle of Subsidiarity and the Division of Powers Within the European Community, 29 Common Mkt. L. Rev. 1107 (1992); Ulrich Everling, Reflections on the Structure of the European Union, 29 Common Mkt. L. Rev. 1053, 1071 (1992). For a general discussion of the concept, see Chantal Million-Delsol, Le Principe de Subsidiarité (1993).

3. According to one British columnist, former Prime Minister Thatcher described the term subsidiarity as "gobbledegook." Philip Howard, The Times (London), Oct. 15, 1992, at 16; see also Mackenzie-Stuart, supra note 1 (similarly describing the term).

4. See Reinhard Rack, Social Legislation in the European Community and in the Member States-A Case of Subsidiarity?, Paper Delivered at Symposium on Subsidiarity and Harmonization: Defining European Federalism, Rutgers (Camden) School of Law (Mar. 26, 1993) (on file with the Columbia Law Review).

5. See A.G. Toth, The Principle of Subsidiarity in the Maastricht Treaty, 29 Common Mkt. L. Rev. 1079, 1105 (1992). According to Toth, the principle of subsidiarity is not only not part of pre-Maastricht Community law but [also] totally alien to and contradicts the logic, structure and wording of the founding Treaties and the jurisprudence of the European Court of Justice." Id. at 1079.

6. Jacques Delors, The Principle of Subsidiarity: Contribution to the Debate, in Subsidiarity: The Challenge of Change 7, 16 (Proceedings of Colloquium organized by European Institute of Public Administration, Mar. 21-22, 1991).

7. Id. at 13; see also Jean-Louis Dewost, EC Model at the Crossroads: The EC Perspective on Subsidiarity 8 (Salzburg Seminar on Perspectives on Federalism, Salzburg; Austria, May 28, 1993) (describing subsidiarity as a doctrine that might lead to curtailment of the powers of the European Commission and reversion to more intergovernmental action). In its latest communication on subsidiarity, the Commission called attention to this risk and stated its determination to avoid it. Thus, subsidiarity "cannot be used as a pretext for challenging measures in areas such as the internal market where the Community has a clearly defined and undeniable obligation to act," and "debate should 
drafters of the Maastricht Treaty on European Union (TEU) nevertheless chose to make the principle a central tenet of the Community's latest constitutional reform. ${ }^{8}$

As set out in the TEU, subsidiarity enjoins the institutions of the Community to act in areas of concurrent competence "only if and insofar as the objectives of the proposed action cannot be sufficiently achieved by the Member States."9 According to the principle, the Community institutions should refrain from acting, even when constitutionally permitted to do so, if their objectives could effectively be served by action taken at or below the Member State level. The drafters' apparent purpose was to reassure Member State populations, and subcommunities within those populations, that the Community's seemingly inexorable march toward greater legal and political integration would not needlessly trample their legitimate claims to democratic self-governance and cultural diversity.

In this Article, I seek to understand the apparent contradiction between subsidiarity's high claims and its relatively low esteem. The Article consists of four parts. Part I offers a largely historical explanation for the importance that Community leaders have apparently ceded to subsidiarity, while Part II confronts the realities of making subsidiarity in Europe more than a purely rhetorical device. In Part III, I conduct a search for subsidiarity as a principle and practice of U.S. federalism, in the belief that the exercise may instruct us about the utility for the Community of an instrument as seemingly problematic as subsidiarity, as well as about the relationship between subsidiarity and federalism more generally. Part IV sets out the results of this comparison.

My overall reasoning and conclusions are as follows. In the first place, it seems clear that making subsidiarity into a meaningful and manageable instrument of political control will not in any event be an easy task. Therefore, before requiring that the political branches practice subsidiarity, or that the Court of Justice possibly police their performance in

not be reopened ... on the fundamental principles of Community policies, or on particular points of an instrument considered essential by one or other Member State." Commission Report to the European Council on the Adaptation of Community Legislation to the Subsidiarity Principle, COM(93)545 final at 2,6. In general, this Report seems to illustrate the significant difficulties involved in implementing subsidiarity, especially in so far as revisions of existing legislation are concerned. Id. at 5-8.

8. According to Article A of the Treaty on European Union [TEU], the European Communities, including the EEC, constitute "a European Union." This "new stage in the process of creating an ever closer union among the peoples of Europe," id., entails, in addition to the Communities, certain forms of intergovernmental cooperation, notably in justice and home affairs, TEU, tit. VI, and foreign and security policy, TEU, tit. V. Moreover, Article $\mathrm{G}$ of the TEU amends the Treaty Establishing the European Economic Community in order to rename the European Economic Community (EEC) the European Community (EC). For simplicity's sake, I refer throughout this article to the EC Treaty. Technically speaking, that Treaty was known as the EEC Treaty (Treaty Establishing the European Economic Community) up until the entry into force of the TEU.

9. TEU art. G(5), adding a new Article $3 b$ to the Treaty Establishing the European Economic Community [EC Treaty]. See infra note 41 and accompanying text. 
doing so, one must first mount a strong case for the principle itself. Subsidiarity, in other words, must not only mean something; it must matter. Part I of this Article accordingly seeks to define the subsidiarity principle and to show why it has assumed such singular significance in the Community's present constitutional situation. In my view, the principle of subsidiarity is not only a plausible response to the federalism patterns that have developed in the Community over the past thirty-five years, but a compelling one.

I also conclude that, while elusive and sometimes deeply confusing, subsidiarity is a meaningful and useful notion. However, I maintain that in order for subsidiarity to achieve its purpose-namely to redress what is claimed to be a serious and growing power imbalance within the Community's divided-power system ${ }^{10}$-it will have to be practiced as well as preached. If political participants conclude that other players succeed in paying pure lip service to subsidiarity, they will be tempted to do likewise; in that event, subsidiarity, far from reassuring Member States, will only erode whatever confidence they have in the Community and its institutions. To be taken seriously, subsidiarity must direct a genuine legislative inquiry into the consequences of the Community's refraining from taking a measure that it may legitimately take, in deference to the Member States' capacity to accomplish the same objectives. Moreover, even if they conduct a credible subsidiarity inquiry, the Community institutions may have difficulty demonstrating that they have practiced subsidiarity in fact. This is the case in part because one's judgment about whether a measure comports with the principle of subsidiarity is a profoundly political one, in the sense that it depends intimately on one's assessment of the measure's merits; it is also the case, however, because the practice of subsidiarity entails predicting the consequences, in terms of the attainment of Community objectives, of allowing the Member States to act. It is fully an exercise in speculation as well as judgment.

Part II thus addresses the extremely difficult analytic aspects associated with putting subsidiarity into practice. In this Part, I first examine what practicing subsidiarity might entail for the political branches, drawing as much as possible from the guidelines announced at the European Council's 1992 Edinburgh Summit, ${ }^{11}$ but also heavily amplifying them. I compare the principle of subsidiarity in this regard with the fundamental

10. The term "divided-power system" comes from Eric Stein, On Divided-Power Systems: Adventures in Comparative Law, 1983/1 Legal Issues of Eur. Integration 27 (1983). See also Koen Lenaerts, Constitutionalism and the Many Faces of Federalism, 38 Am. J. Comp. L. 205, 263 (1990) ("Federalism is present whenever a divided sovereign is guaranteed by a national or supranational constitution and umpired by the supreme court of the common legal order.").

11. See European Council in Edinburgh, Conclusions of the Presidency, Dec. 12-13, 1992 (summarizing results of the Edinburgh Summit) [hereinafter Edinburgh Conclusions]. See generally European Community: Cheery Faces, The Economist, Dec. 19,1992 , at 48 . 
Community principle of proportionality, ${ }^{12}$ concluding that the two bear a much more awkward relationship to each other than is commonly supposed, and that resolving their tensions raises an even more decidedly "political" question than either principle raises alone.

Subsidiarity accordingly presents the Community with a special challenge. By its nature the principle is one that the Community institutions may plausibly be said to violate every time they determine whether or not to act. My basic view is that the Community should respond to this challenge by recasting subsidiarity from a jurisdictional principle (that is, a principle describing the allocation of substantive authority between the Community and the Member States) into an essentially procedural one (that is, a principle directing the legislative institutions of the Community to engage in a particular inquiry before concluding that action at the Community rather than Member State level is warranted).

The same considerations I have just described also suggest that the Court of Justice ${ }^{13}$ should consider subsidiarity to be a justiciable issue, but that the nature of the review and the degree of judicial scrutiny entailed should reflect subsidiarity's highly problematic character. The Court should insist that, before adopting a measure, the Community institutions inquire meaningfully into the capacity of the Member States to attain the objectives that the measure is intended to achieve and explain why they conclude that action at the Community level is necessary. In ensuring that the institutions ask and answer the right questions before acting, the Court in effect enforces a procedural mandate, something it is well equipped to do.

The Court is not, however, especially well equipped to make the substantive judgment as to whether the institutions correctly identified and assessed the consequences of Community inaction; at the very most it can determine whether the institutions' decision to act, based on the information available to them, was egregiously mistaken. Although the Court's level of scrutiny should therefore be plainly and unapologetically deferential, its willingness to entertain the question of subsidiarity would significantly reinforce its essential procedural demand that the political

12. The principle of proportionality holds that "the individual should not have his freedom of action limited beyond the degree necessary for the public interest." Case 11/ 70, Internationale Handelsgesellschaft $\mathrm{GmbH}$ v. Einführ-und Vorratsstelle für Getreide und Futtermittel, 1970 E.C.R. 1125, 1127, [1972] 10 C.M.L.R. 255, 256. See generally Derrick Wyatt \& Alan Dashwood, European Community Law 89-91 (3d ed. 1993).

13. The Court of Justice of the European Communities is responsible for "ensur[ing] that in the interpretation and application of [the EC treaty] the law is observed." EC Treaty art. 164. Upon request from Member State courts, it may render preliminary rulings on the validity and interpretation of community acts. The court also hears original actions against both the Member States and the Community institutions themselves for alleged breaches of Community law. On the Court, see generally George A. Bermann et al., Cases and Materials on European Community Law 69-72, 96-165 (1993); Ulrich Everling, The Court of Justice as a Decisionmaking Authority, 82 Mich. L. Rev. 1294 (1984). See infra note 142. 
branches themselves take subsidiarity seriously. Finally, I suggest that the Court of Justice may actually have before it an even more difficult task than deciding whether and how to police the institutions' respect for the principle of subsidiarity; the Court may have to examine the impact of its own case law on the balance between the Community and the Member States and, more specifically, square the principle of subsidiarity with its far-reaching jurisprudence on the direct effect ${ }^{14}$ of the Community treaties.

Although subsidiarity has not figured as a term in United States constitutionalism, it plainly touches on issues of enduring concern to the federalism balance in this country as well. Part III of this Article analyzes critically the attempts that have been made in the United States to confine legally the exercise by the federal government of powers that are, jurisdictionally speaking, its to exercise, so as to allow state and local governments to act where they can satisfactorily do so. The inquiry is necessarily a far-ranging one, covering sources of authority as diverse as the Tenth Amendment and various Executive Orders addressed to the federal agencies, and drawing upon both statements of principle and patterns of practice. My conclusion, upon examining these sources, as well as the general drift of reform, is that while there are growing misgivings in the United States about leaving the state of federalism entirely to an unstructured political process, no real attempt has been made to ensure respect for subsidiarity as such, either as a jurisdictional or a procedural principle. The federal political process is still relied upon to guarantee that due attention will be paid to the values of localism.

I nevertheless conclude in Part IV that the U.S. experience should not cause the Europeans to shy away from taking subsidiarity seriously. After surveying certain obvious differences in the settings of U.S. and EC federalism, I weigh the importance in regard to subsidiarity of the Community's distinctive institutional arrangements. I find that, although the Council of Ministers of the Community ${ }^{15}$ represents the Member States as such, it offers even weaker assurances than Congress that policy choices on matters of predominantly local concern will be left in the hands of the states and their political subcommunities; I further find that none of the other Community institutions affords substantial assurances

14. Under the principle of direct effect, national courts may be bound to recognize and enforce the rights or obligations placed on individuals by Community law. The Court of Justice established the principle in Case 26/62, Van Gend en Loos v. Nederlandse Administratie der Belastingen, 1963 E.C.R. 1, 12, [1963] 2 C.M.L.R. 105, 117. See infra notes $57-71$ and accompanying text.

15. The Council of Ministers is the Community's chief legislative body. It consists of representatives of each of the twelve Member States. Representatives vote in the Council in the name of the Member State that they represent. Action on some issues requires unanimity among the twelve ministers. Action on other issues requires an absolute majority vote, i.e., support by seven Member States. A third, and rapidly growing, category of issues requires qualified majority voting. On the workings of qualified majority voting, see infra note 38 . 
of that sort either. Moreover, I observe that while the Community is heavily dependent on the Member States for its resources, it also systematically lays claim to the States' own resources in precisely those ways that would be frowned upon as "commandeering" under emerging U.S. Supreme Court doctrine. ${ }^{16}$ For both of these reasons, subsidiarity should be taken especially seriously in Europe.

Judging by the U.S. experience, even a proceduralized requirement of subsidiarity will be difficult to police effectively; determining whether Member State measures can adequately accomplish Community objectives will prove to be a delicate and irreducibly political exercise, much as the parallel exercise in the United States has been. Nevertheless, the Court of Justice will substantially enhance the legitimacy of the Community's limitations on State sovereignty if it requires the institutions to make the relevant legislative analyses before taking action in areas of shared competence. The Court will thereby help the Community to take subsidiarity seriously, while at the same time respecting the proper institutional balance between itself and the Community's political branches.

\section{SUbSidiarity AND the EUROpEAN COMmUNITY}

The notion that action should be taken at the lowest level of government at which particular objectives can adequately be achieved can be applied in any polity in which governmental authority is lodged at different vertical levels. In a federal system (or a system developing along federal lines) the power-sharing at issue will commonly be between the central government and the constituent states. ${ }^{17}$ In the European Com-

16. See infra Part III.C.

17. The allocation of governmental authority within each Member State may, of course, also be subjected to a principle of subsidiarity. This possibility is most obvious in a Member State such as Germany, which itself is organized as a federal system, or in such prospective Member States as Austria or Switzerland. Some EC Member States, notably Belgium, Italy, Spain, and the UK, have regional subdivisions which, while falling short of constituent states as such, can and sometimes do advance subsidiarity-based claims. Finally, every State, even the most unitary, exhibits power-sharing between central and a variety of different levels of more local authority.

The German Constitution (Grundgesetz or Basic Law) provides that, in areas of shared competence, the federal government may legislate only if necessary, that is, if the states cannot effectively achieve the goal sought. Article 72(2) provides:

The Federation shall have the right to legislate on [matters within the concurrent legislative powers of the Federation and the Länder (states)] to the extent that a need for regulation by federal law exists because:

1. a matter cannot be effectively regulated by the legislation of individual Länder, or

2. the regulation of a matter by a Land law might prejudice the interests of other Länder or of the entire community, or

3. the maintenance of legal or economic unity, especially the maintenance of uniformity of living conditions beyond the territory of a Land necessitates such regulation. 
munity context, this essentially means Brussels and the Member States, respectively.

Advocates of subsidiarity in the European Community trace the concept to twentieth-century Catholic social philosophy, citing a 1931 Papal Encyclical of Pius XI entitled Quadragesimo anno. ${ }^{18}$ According to that document, subsidiarity requires that "[s]maller social units . . . not be deprived of the possibility and the means for realizing that of which they are capable [and] [1] arger units . . . restrict their activities to spheres which surpass the powers and abilities of the smaller units." 19 For reasons that will become clear in the next section, Community leaders were content to distill from the ecclesiastical literature on subsidiarity a very rudimentary but quite suggestive concept. Though solemn in tone, and certainly solemn in origin, subsidiarity nevertheless speaks in unmistakably political terms. In this Part, I seek a better understanding of the concept of subsidiarity, first and briefly as a purely analytic matter, and then much more extendedly as a response to the European Community's distinctive legal and political evolution.

\section{A. Toward Clarity about Subsidiarity}

Subsidiarity expresses a preference for governance at the most local level consistent with achieving government's stated purposes. Although the virtues of local governance are sometimes treated as self-evident, they actually depend on our willingness to draw connections between local governance and certain more fundamental values. It is important to identify these values, both because subsidiarity should not be viewed in

Grundgesetz [Constitution] art. 72 (Germany). See generally Nicholas Emiliou, Subsidiarity: An Effective Barrier Against "the Enterprises of Ambition?," 17 Eur. L. Rev. 383, 388-90 (1992).

18. [I] $t$ is a fixed and unchangeable principle ... that just as it is wrong to take away from individuals what they can accomplish by their own ability and effort and entrust it to a community, so it is an injury and at the same time both a serious evil and a disturbance of right order to assign a larger and higher society what can be performed successfully by smaller and lower communities. The reason is that all social activity, of its very power and nature, should supply help [subsidium] to the members of the social body, but may never destroy or absorb them. . . . Let those in power, therefore, be convinced that the more faithfully this principle of subsidiarity function is followed and a graded hierarchical order exists among the various associations, the greater also will be both social authority and social efficiency, and the happier and more prosperous too will be the condition of the commonwealth.

Joseph Komonchak, Subsidiarity in the Church: The State of the Question, 48 The Jurist 298, 299 (1988) (quoting Pius XI, Quadregismo Anno § 79 (1931)).

19. Franz-Xaver Kaufmann, The Principle of Subsidiarity Viewed by the Sociology of Organizations, 48 The Jurist 275, 280 (1988); see also Thomas J. Green, Subsidiarity During the Code Revision Process: Some Initial Reflections, 48 The Jurist 771, 798-99 (1988) (quoting Cardinal Döpfner's statement at the 1969 synod to the effect that subsidiarity "signifies that the higher instances and organisms must respect the capacities, competences and tasks of individuals and communities, in theory and in practice [so that] ... a healthy and vigorous life, adapted to different situations, can develop"). 
isolation from them-as if an end in itself-and because intelligent application of the subsidiarity principle on any given occasion may require knowing precisely what values are at stake.

1. Self-Determination and Accountability. - Individuals are generally thought to have a greater opportunity to shape the rules governing their personal and business affairs when those rules are made at levels of government at which they are more effectively represented. The opportunity to participate increases the likelihood that the law and policy that result will reflect the interests of the population concerned and will, on that account, enhance the individual's sense of dignity and autonomy within the larger community. In both respects, self-determination advances essentially democratic values. ${ }^{20}$

Just as localism tends to enhance a community's self-determination in the initial making of policy, it also enhances its self-determination in the reaction to policy once made and implemented. A community is simply better able to express its dissatisfaction with government when government is continuously dependent on that community for support. ${ }^{21}$ In other words, heightened political accountability of government to a community is an important dimension of that community's selfdetermination.

20. The European Council, meeting at Edinburgh in 1992, emphasized that subsidiarity brings decision-making "as closely . . . as possible to the citizen." Edinburgh Conclusions, supra note 11, Annex 1 to Part A, at 2. On the linkage between subsidiarity and self-determination, see Delors, supra note 6, at 8-9. Joseph Weiler in effect described the relationship of subsidiarity to democracy and control when he wrote:

[T] he European electorate (in most Member States) only grudgingly accepts the notion that crucial areas of public life should be governed by a decisional process in which their national voice becomes a minority which can be overridden by a majority of representatives from other European countries. . . . [T]here is, arguably, [not yet a consensus] that the boundaries within which a minority will accept as democratically legitimate a majority decision are now European instead of national.

J.H.H. Weiler, The Transformation of Europe, 100 Yale L.J. 2403, 2472-73 (1991) [hereinafter Weiler, Transformation]. See also Alain G. Gagnon, The Political Uses of Federalism, in Comparative Federalism and Federation 15 (M. Burgess \& A. Gagnon eds., 1993) [hereinafter Comparative Federalism] (arguing that federalism serves as a shield for minority groups" and provides a means for the expression of innovative democratic practices).

The constitutional principle of democracy played a major role in the constitutional challenge in Germany to that country's ratification of the Maastricht Treaty on European Union. In its October 1993 ruling, the German Constitutional Court held that the German Parliament could not constitutionally ratify a treaty that deprived the German people of their right to democratic participation, but that ratification of the Maastricht Treaty did not entail such a deprivation. See Judgment of Oct. 12, 1993, Bundesverfassungsgericht [Constitutional Court] 2 BVerfG 2134/92, 2 BVerfG 2159/92 (Germany) [hereinafter German Constitutional Court Maastricht Decision]; see also Michael Burgess \& Franz Gress, The Quest for a Federal Future: German Unity and European Unrest, in Comparative Federalism, supra, at 168.

21. See Centre for Economic Policy Research, Making Sense of Subsidiarity: How Much Centralization for Europe? 41-42 (1993) [hereinafter Making Sense]. 
2. Political Liberty. - Subsidiarity may also advance democratic values through its tendency toward the fragmentation of power. Although James Madison forcefully underscored the advantages of larger units of government in limiting the political power of "factions," or dominant local interests, ${ }^{22}$ the framers of the U.S. Constitution acted on the basic belief that individual freedom would be advanced by preventing the undue concentration of power in the same governing hands. ${ }^{23}$ To the extent that subsidiarity promotes the diffusion of authority among different levels of government within the European Community, it can serve as a similar check against political oppression and tyranny and, like self-determination, also promote individual freedom. ${ }^{24}$

3. Flexibility. - Much as it may help to promote individual selfdetermination, subsidiarity permits a community to reflect more closely the unique combination of circumstances-physical, economic, social, moral, and cultural-that obtain at any given moment. It may also enable the community to respond appropriately to the changes of circumstances that occur within it from time to time. By enhancing the law's responsiveness to the population it serves, subsidiarity affords a flexibility that advances democracy at the same time as it produces good government.

4. Preservation of Identities. - One result of organizing power in ways that promote self-determination and responsiveness is that local populations can better preserve their sense of social and cultural identity. The law is of course not the only or even the main determinant of identity, but it can be an important instrument in strengthening or diluting the specificity of a community's distinctive combination of forms and values. ${ }^{25}$

5. Diversity. - At the same time as it affords local populations the benefits of self-determination and responsiveness, and thereby encourages the survival of social and cultural identities, subsidiarity also fosters

22. Among the numerous advantages promised by a well-constructed Union, none deserves to be more accurately developed than its tendency to break and control the violence of faction. ... . To secure the public good and private rights against the danger of . . . faction, and at the same time to preserve the spirit and the form of popular government, is then the great object to which our inquiries are directed.

The Federalist No. 10, at 16, 19-20 (James Madison) (Roy P. Fairfield ed., 1981). See also Cass R. Sunstein, After the Rights Revolution: Reconceiving the Regulatory State 14-15 (1990) (discussing Madison's view of republican government).

23. This belief is manifested both in the doctrine of separation of powers and in the general reservation of governmental action to the states. See generally The Federalist Nos. 45, 46 (James Madison).

24. See Emiliou, supra note 17 , at $385-86$.

25. The European Council, meeting at Edinburgh in 1992, asserted that subsidiarity "contributes to ... respect for the national identities of Member States," at the same time as it "safeguards their powers." See Edinburgh Conclusions, supra note 11, at 2. For a discussion of the relation between federalism and the preservation of cultural identities, see Daniel J. Elazar, Exploring Federalism 6, 33, 99 (1987); Sunstein, supra note 22, at 35. 
diversity within the larger polity. Social and cultural diversity may be valued in its own right, ${ }^{26}$ but it may also be considered conducive to social, cultural and political experimentation, and therefore instrumentally advantageous as well. ${ }^{27}$

6. Respect for Internal Divisions of Component States. - A further virtue of subsidiarity-one with particular resonance in the Community-is its tendency to preserve the formal allocations of power internal to the Member States themselves. The transfer of normative powers to the Community has unquestionably disturbed the preestablished federalism balance within the Federal Republic of Germany and may have similar effects in other Member States. As representatives of the German Länder have argued, ${ }^{28}$ governance of certain matters that under the German

26. See Jacques Santer, Some Reflections on the Principle of Subsidiarity, in Subsidiarity: The Challenge of Change, supra note 6, at 19, 30 (claiming that "extraordinary and rich diversity ... . is Europe's greatest asset").

27. See Klaus Gretschmann, The Subsidiarity Principle: Who Is to Do What in an Integrated Europe?, in Subsidiarity: The Challenge of Change, supra note 6, at 45, 50-51 (European diversity "represents a playground for experiments.").

The theme of states as "laboratories" for social and economic experimentation is not exclusively European. See New State Ice Co. v. Liebmann, 285 U.S. 262, 311 (1932) (Brandeis, J., dissenting) (" $[\mathrm{A}]$ single courageous State may ... serve as a laboratory; and try novel social and economic experiments without risk to the rest of the country.").

28. See Bruno De Witte, Community Law and National Constitutional Values, 1991/2 Legal Issues of Eur. Integration 1, 13-14 (1991); Editorial Comments, The Subsidiarity Principle, 27 Common Mkt. L. Rev. 181, 182 (1990); Marc Wilke \&c Helen Wallace, Subsidiarity: Approaches to Power-Sharing in the European Community 3-4 (Royal Institute of International Affairs, Discussion Paper No. 27, 1990). In fact the notion of subsidiarity surfaced specifically in the 1988 discussions in Bonn between Commission President Delors and the Minister-Presidents of the German Länder. See Delors, supra note 6, at 9. For a discussion of constitutional amendments introduced in Germany to strengthen the voice of the Länder in Germany's participation in Community decisionmaking, see infra note 264 and accompanying text.

In its October 1993 decision upholding the constitutionality of the German law ratifying the Maastricht Treaty (as well as the laws amending the German Basic Law to permit the ratification), the German Constitutional Court declined to decide whether the Treaty violated the basic constitutional principle of federalism. That particular claim was deemed inadmissible. However, the Court ruled that the constitutional principle of democratic legitimacy requires that the Member States retain a certain minimum of sovereign legislative power:

As long as the peoples of the Member States remain the source of democratic legitimacy acting through the intermediary of the national parliament-as is the case at present-the principle of democracy places limits on the expansion of competences of the European Communities .... The States must have areas of their own competence that are sufficiently large, in which the people of each State can express and organize themselves within the framework of a process of defining their political will, legitimated and directed by that people in such a way as to give legal expression to that which unites them, at least relatively homogeneously, on the spiritual, social and political level.

It follows from this that the Member State legislature must reserve powers and competences of some substantial importance.

German Constitutional Court Maastricht Decision, supra note 20, at 46-47. The Court concluded under the circumstances that "the grant of powers and competences to the 
Constitution are theirs to govern has effectively been transferred to the Community, a level at which the Member States' own distinctive subcommunities are not efficiently represented politically. It stands to reason that, by reducing Community intervention to the necessary minimum, subsidiarity tends to slow down this erosion of the power of the Member States' own component parts. ${ }^{29}$ This last consideration underscores the special relationship that exists between subsidiarity and federalism.

Each of these values-self-determination and accountability, political liberty, flexibility, preservation of identities, diversity, and respect for internal divisions of component states-has figured importantly in the rhetoric of subsidiarity in the Community, ${ }^{30}$ sometimes in conjunction with still other values. ${ }^{31}$ More often, however, the term subsidiarity is invoked in the interest of some vague sense of "localism," and without any clear indication of the positive values meant to be served. It is true that discussions of subsidiarity have tended to proceed without close regard to localism's costs either, and that these costs are also real. ${ }^{32}$ Aside from the risk that Madison associated with the dominance of local factions, ${ }^{33}$ the principal risk of subsidiarity in the Community context is its possible impairment of a common internal market and, more generally, its interference with the efficient attainment of the Community's substantive policy goals. Though largely sympathetic to subsidiarity, I endeavor to bring this risk, where relevant, into consideration. The evolution of Community federalism traced in the next two sections shows, however, that it is the putative virtues of subsidiarity, and not its possible drawbacks, that are animating

European Union provided for by the Treaty on European Union still leaves Bundestag sufficient powers and competences of a substantial political weight." Id. at 76.

29. On the other hand, the dispersion of power within a federally-organized Member State may in some respects reduce that State's effectiveness as a governmental mechanism, at least insofar as the attainment of Community objectives is concerned. This may, paradoxically, give the Community institutions greater cause to doubt the efficacy of Member State action as compared to Community action in attaining those objectives and thus, in keeping with the principle of subsidiarity, cause them to take action themselves.

On the importance of the subsidiarity principle to a prospective federal Member State, such as Austria, see Rack, supra note 4.

30. See, e.g., European Council in Brussels, Declaration on the Entry into Force of the Treaty on European Union (Oct. 29, 1993), DOC/93/8.

31. For example, subsidiarity is sometimes assumed to favor the politics of "deregulation," in that the less Brussels regulates, the less regulation there is likely to be. See Henning Christophersen, Subsidiarity and Economic Monetary Union, in Subsidiarity: The Challenge of Change, supra note 6 , at 65,66 . This assumes, however, that Member States will not use subsidiarity as a rationale for national intervention.

32. See Making Sense, supra note 21, at 36-39; A.E. Dick Howard, The Values of Federalism, 1 New Eur. L. Rev. 143, 156-60 (1993) (discussing negative experiences of federalism in the United States).

33. See supra note 22. The Madisonian risk is not as significant in the European Community as it was in America in the 1780s. The Member States are, for the most part, large polities. Moreover, they are mature polities, and those among them that contain cultural minorities at risk of oppression-Belgium, Italy, Spain, and the UK, for examplehave developed internal regional policies to cope with that risk. 
the subsidiarity debate. This Article accordingly gives them more focused attention.

\section{B. Subsidiarity and the European Community Treaties}

Given subsidiarity's linkage to the positive values set out in the previous section, it is not surprising that the European Parliament was the first of the Community institutions to introduce the principle prominently into debates over European federalism. ${ }^{34}$ The Draft Treaty on European Union, which the Parliament produced and overwhelmingly endorsed in 1984 as a blueprint for Community reform, featured subsidiarity as a general constitutional rule. In all matters falling within the concurrent competences of the prospective European Union and the Member States, the Union was only "to carry out those tasks which may be undertaken more effectively in common than by the Member States acting separately."35 The Draft Treaty proved much too ambitious in its federal designs to suit the Member States, and the Luxembourg intergovernmental conference that was convened in the mid-eighties to draft amendments to the Community treaties ultimately settled on a more modest document, the 1986 Single European Act (SEA). ${ }^{36}$ The SEA expressly embraced the principle of subsidiarity, though in one domain only-environmental protection, one of the new competences that the SEA conferred on the Commu-

34. The European Parliament, as described in Article 137 of the EEC Treaty, consists of "representatives of the peoples of the States brought together in the Community." In other words, it represents the people of Europe, rather than either the Community interest itself or the interests of the Member States as such. Except where the Treaty indicates otherwise, the Parliament's legislative role within the Community is basically a consultative one only. Since 1987, its legislative role has been enhanced, notably through introduction of a parliamentary cooperation procedure and a parliamentary co-decision procedure. See infra note 134 and accompanying text.

The term subsidiarity had figured into the Commission's 1975 Report on European Union. See Bull. Eur. Communities Comm'n Supp. 5/75, at 10-11. For discussion of its significance in that context, see Toth, supra note 5, at 1088-89; see also Cass, supra note 2, at 1112-16 (tracking the early development of subsidiarity in the Community).

35. Draft Treaty Establishing the European Union, art. 12(2), 1984 O.J. (C 77) 33, 38. The Draft Treaty suggested that Union action would be appropriate for tasks "whose execution requires action by the Union because their dimension or effects extend beyond national frontiers." Id.

As early as 1982, the European Parliament had formally declared that "[t]he principle of subsidiarity [was] one of the essential principles of the union." Resolution on the European Parliament's Position Concerning the Reform of the Treaties and the Achievement of European Union, 1982 O.J. (C 238) 26.

36. Single European Act [SEA], I Treaties Establishing the European Communities 1005 (Office for Official Publications of the European Communities, 1987); see also Jean De Ruyt, L'Acte Unique Européen 25-65 (1989); Don't Take Europa to Brussels, They Cry, The Economist, Nov. 8, 1986, at 55 (SEA Treaty confers no significant new powers on the Commission, with even majority voting provision easily subjected to minority blocking and veto). 
nity. ${ }^{37}$ While it did not pass unnoticed, this limited appearance of subsidiarity took backstage to other more conspicuous features of the SEA, most notably the decision to permit the Member States to adopt Community legislation in the Council of Ministers by qualified majority voting rather than by unanimity, where such legislation was deemed necessary to create a barrier-free internal market by the end of 1992 . It was easy to dismiss the SEA's limited recognition of subsidiarity as peculiar to the politically sensitive environmental agenda and, even then, as purely hortatory in nature.

If the SEA did not itself spotlight the principle of subsidiarity, it nevertheless created the conditions that would soon make subsidiarity one of the Community's most prominent concerns. Under the system of qualified majority voting, a Commission proposal could ripen into Council legislation over the opposition of several Member States. ${ }^{38}$ This change made it easier for the Council to pass legislation, which in turn made the Commission bolder in its legislative initiatives and more determined in advancing them. The Member States were left in need of new instruments for controlling the Community institutions, especially since the SEA had also extended the Community's sphere of action to new areas (worker health and safety, research and technology, and regional development, as well as environmental protection). Expectations were that the next few years would bring still further treaty amendments, and still new legislative competences for the Community, among them the creation of an economic and monetary union. ${ }^{39}$

It is no coincidence then that the 1992 Maastricht Treaty on European Union (TEU) -which emerged from two 1990 intergovernmental conferences, one on economic and monetary union and the other on European political union-put subsidiarity in plain view, making it a central principle of Community law. Article A of the TEU proclaims that in the new European Union, "decisions are [to be] taken as closely as possible to the citizen." 40 Article B of the TEU requires the Community institutions, in pursuing their objectives under the TEU, to "respect . . . the principle of subsidiarity," a principle spelled out as such in a new Article $3 \mathrm{~b}$ added to the EC Treaty:

37. "The Community shall take action relating to the environment to the extent to which the objectives [assigned to it] can be attained better at [the] Community level than at the level of the individual Member States." EC Treaty art. 130r(4) (as amended 1987).

38. Under qualified majority voting, the Member States have differing numbers of votes depending very crudely on their relative populations. Luxembourg has two votes; France, Germany, Italy, and the UK have ten apiece; the others have numbers in between. The current total votes in the Council under qualified majority voting is 76 , and 54 affirmative votes are required for action. All of a state's votes are cast as a bloc.

39. See Report of the Committee for the Study of Economic and Monetary Union [hereinafter the Delors Committee Report] Bull. Eur. Communities Comm'n, Sept. 1989 at 8, which outlined the essentials of an economic and monetary union and expressly called for application of the principle of subsidiarity to legislation in that area.

40. TEU, art. A. 
In areas which do not fall within its exclusive competence, the Community shall take action, in accordance with the principle of subsidiarity, only if and in so far as the objectives of the proposed action cannot be sufficiently achieved by the Member States and can therefore, by reason of the scale or effects of the proposed action, be better achieved by the Community. ${ }^{41}$

As if to emphasize the connection between subsidiarity and the expansion of the Community's powers, the drafters of the TEU put language into virtually every new treaty chapter underscoring their intention that the Member States continue to exercise primary responsibility in these new Community spheres. This is the case with education, ${ }^{42}$ vocational training, ${ }^{43}$ culture, ${ }^{44}$ health, ${ }^{45}$ consumer protection, ${ }^{46}$ and industrial competitiveness, ${ }^{47}$ each of which the TEU brings within the sphere of Community action.

The drafters took similar precautions with matters that the TEU does not make into Community competences as such, but nevertheless expressly subjects to Community "coordination." I refer here chiefly to the TEU's separate title on cooperation in the fields of justice and home af-

41. EC Treaty art. 3b (as amended 1992). The final paragraph of the new Article 3b reads: "Any action by the Community shall not go beyond what is necessary to achieve the objectives of this Treaty." Id. This paragraph expresses what is commonly known as the principle of proportionality. See infra notes $157-160$ and accompanying text.

42. The TEU (amending EC Treaty art. 126) guarantees that the Community, while contributing to educational quality, will "fully respect[ ] the responsibility of the Member States for the content of teaching and the organization of education systems and their cultural and linguistic diversity." EC Treaty art. 126(1) (as amended 1992).

43. The TEU (amending EC Treaty art. 127) guarantees that the Community, while supporting and supplementing the Member States' vocational training policies, will "fully respect[] the responsibility of the Member States for the content and organization of vocational training." EC Treaty art. 127(1) (as amended 1992).

44. The TEU binds the Community to respect the Member States' national and regional diversity even while "bringing the common cultural heritage to the fore." EC Treaty art. 128(1) (as amended 1992).

45. The TEU (amending EC Treaty art. 129) emphasizes that the Community's legislative role in the field of health is confined to "encouraging cooperation between the Member States and, if necessary, lending support to their action." EC Treaty art. 129(1) (as amended 1992).

46. The TEU (amending EC Treaty art. 129a) similarly limits the Community to taking such consumer protection action as "supports and supplements the policy pursued by the Member States." EC Treaty art. 129a(1) (b) (as amended 1992).

47. The TEU (amending EC Treaty art. 130) simply calls on the Commission to "promote" coordination among the Member States in their industrial policies and otherwise to take specific measures "in support of action taken in the Member States" to foster industrial competitiveness. EC Treaty art. 130g (as amended 1992). The SEA, in adding EC Treaty Article $130 \mathrm{~g}$ on research and technological development, had similarly confined the Community to "complementing the activities carried out in the Member States." 
fairs ${ }^{48}$ and to the separate Agreement on Social Policy, ${ }^{49}$ which was in fact concluded outside the EC Treaty framework and only among the eleven Member States other than the UK. Both texts contain language highly suggestive of subsidiarity. ${ }^{50}$ Viewed as a whole, the Maastricht Treaty thus reflects a strong linkage between the expansion of Community competences and the necessity of self-restraint in their exercise.

Some observers have doubted that the drafters of the Maastricht Treaty could possibly have taken the principle of subsidiarity seriously if they coupled it with so significant an extension of Community powers. A recent study by leading European economists concludes that the drafters erred not only in making macroeconomic policy and social policy matters of Community concern, but also in failing to reduce the scale of Community involvement in existing competences, such as agricultural policy, labor and capital mobility, regional development, and much of environmental regulation. ${ }^{51}$ By contrast, I see no contradiction, either logically or politically, between extending the field in which the institutions may take action and requiring them to practice self-restraint in do-

48. The TEU, art. K.3(2) (b), invites the Council, on the initiative of a Member State (or in some cases the Commission) to adopt joint action on asylum, border controls, immigration policy, .control of drug trafficking and addiction, anti-terrorism activities, international crime prevention, and judicial cooperation in civil and criminal matters, but only "in so far as the objectives of the Union can be attained better by joint action than by the Member States acting individually on account of the scale or effects of the action envisaged." Id.

49. Article 1 of the Agreement on Social Policy, annexed to the Protocol on Social Policy (which is itself attached to the TEU), requires the Community and the States to "implement measures which take account of the diverse forms of national practices." More to the point, Article 2 of the Agreement describes the Community's role as "support[ing] and complement[ing] the activities of the Member States" in fields covered by the term "social policy" (worker health and safety, working conditions, worker consultation, equality of men and women in access to and conditions of employment, and expansion of the labor market). TEU, Protocol on Social Policy, Agreement on Social Policy, arts. 1, 2, Bull. Eur. Communities Comm'n Supp., 1992.

The 1989 Social Charter, whose program the Protocol and Agreement on Social Policy seek to implement, itself incorporates subsidiarity. According to paragraph 27 of the Charter: "It is more particularly the responsibility of the Member States, in accordance with national practices ... to guarantee the fundamental social rights in this Charter and to implement the [necessary] social measures." European Community Charter of the Fundamental Social Rights of Workers, I 27 (Office for Official Publications of the European Community, 1989). The Preamble of the Charter specifically reaffirms the principle of subsidiarity: “[B]y virtue of the principle of subsidiarity, responsibility for the initiatives to be taken with regard to the implementation of these social rights lies with the Member States or their constituent parts and, within the limits of its powers, with the European Community." Id.

50. See supra notes $48-49$.

51. See Making Sense, supra note 21. The authors of the report were understandably most dubious about the Community's involvement in social policy. "The Social Chapter of the Maastricht Treaty is ... in direct contradiction with the subsidiarity principle that the same Treaty espouses." Id. at 114. See also Figuring Out Subsidiarity, The Economist, Nov. 27, 1993, at 58. 
ing so. The major difficulty with my position is that it positively requires taking subsidiarity seriously.

\section{Subsidiarity and the Evolution of Community Federalism}

What accounts for the urgency with which subsidiarity has been pressed upon the European Community? The answer to this question lies in the magnitude of constitutional change that the Community has experienced over its brief history. ${ }^{52}$ Certain elements of what Joseph Weiler calls the "transformation" of Europe ${ }^{53}$ were immediately apparent at the time they occurred, chiefly because they took the form of explicit doctrinal pronouncements by the Court of Justice and because they differed markedly from conventional assumptions about the relationship between domestic and international law. Other aspects of the transformation were less conspicuous. But the cumulative effect was to alter profoundly the balance of power between the Community and the Member States, and eventually generate pressures for a doctrine like subsidiarity.

1. The Court of Justice and its Supranationalist Creation. - The Court's fundamental doctrines concerning the relationship between Community law and the law of the Member States-notably the doctrines of direct applicability, direct effect, and supremacy, expounded by the Court in a series of rulings of the early $1960 \mathrm{~s}^{54}$-are by now well known. ${ }^{55}$ While this section does not dwell on these doctrines, it examines their role in escalating the rhetoric of subsidiarity.

The principle of direct applicability posits that the adoption of legal norms by the Community institutions is sufficient to integrate them into the legal orders of the Member States as well. In other words, whatever a State's ordinary treatment of international agreements might be, Community enactments do not need to be transposed, incorporated, or otherwise formally received into a Member State's law in order to become law

52. I date the existence of the Community from January 1, 1958, when the EEC Treaty came into effect. See Multilateral Treaties: Index and Current Status 215 (M.J. Bowman \& D.J. Harris eds., 1984). In fact, the Treaty Establishing the European Coal and Steel Community (ECSC) came into effect in 1952. See id. at 168.

53. See Weiler, Transformation, supra note 20, at 2405.

54. See generally Jacques H.J. Bourgeois, Effects of International Agreements in European Community Law: Are the Dice Cast?, 82 Mich. L. Rev. 1250 (1984) (examining the influence of doctrine regarding relations between Community and Member State law on that regarding relations between international and Community law). For analysis of direct applicability and direct effect, see John H. Jackson, Status of Treaties in Domestic Legal Systems: A Policy Analysis, 86 Am. J. Int'l L. 310 (1992) (examining the direct applicability of international treaties in national legal systems). On the doctrine of supremacy, see Antonio La Pergola \& Patrick Del Duca, Community Law, International Law and the Italian Constitution, 79 Am. J. Int'l L. 578 (1985) (analysis and comparison of the interpretations of the Court of Justice of the European Communities and their application by the Italian Constitutional Court).

55. See, e.g., Lenaerts, supra note 10, at 208-13; Eric Stein, Lawyers, Judges, and the Making of a Transnational Constitution, 75 Am. J. Int'l L. 1, 9-10 (1981). 
within that State. ${ }^{56}$ The direct effects doctrine makes the further claim that Community law norms, if expressed clearly and unconditionally enough, confer on private parties rights that are legally enforceable against the Member States and that the institutions of those States, administrative and judicial alike, are required to protect. Put differently, a directly effective Community norm imposes obligations on the governments of the Member States in favor of private parties, which the latter may invoke directly, if need be, in national courts.

Lastly, the principle of supremacy mandates that Member State officials give precedence to Community law over national law in the event of a conflict between them. That the drafters failed to include an express Supremacy Clause in the EEC Treaty did not prevent the Court of Justice from inferring one, basing it on the necessity that the Community possess legal unity and that Community law be effective throughout the territory of the Member States. ${ }^{57}$ In fact, the original Treaties contained no very clear or general statement of any of these three basic doctrines of the Court.

The doctrines of direct applicability, direct effect, and supremacy are by their nature expansive of Community law in relation to national law, and were readily seen as such, particularly as against the background of traditional attitudes toward the force and effect of international law in the national legal orders. Their claims have accordingly been described as "supranationalist." 58 Moreover, these doctrines not only describe legal relationships, but actually demand Member State action. Direct applicability, direct effect, and supremacy essentially require, respectively, that national institutions recognize Community measures as law, effectuate those measures at the request of private parties wherever appropriate, and prefer claims based on Community law to those based on Member State law whenever a choice must be made.

At least as significant as the Court's early espousal of direct applicability, direct effect and supremacy, and the absence of a clearly and generally stated basis for them in the original Treaty texts, has been the Court's subsequent elaboration of these concepts. From the highly generalized notion of direct effect, for example, the Court eventually drew more or less explicitly the following specific corollaries:

56. The Court of Justice has in fact ruled that a Member State acts illegally when it incorporates directly applicable Community law in such a way as to conceal its Community origins and character. See T.C. Hartley, The Foundations of European Community Law 197-98 (2d ed. 1988) (citing Case 34/73, Fratelli Variola S.p.A. v. Amministrazione Italiana delle Finanze, 1973 E.C.R. 981, [1974 Transfer Binder] Common Mkt. Rep. (CCH) I 8226).

57. The Court justified all three doctrines in terms of their effet utile. Unless Community law were directly applicable, directly effective, and supreme, the Community might fail to accomplish its purposes effectively. See infra notes 59, 72.

58. See Robert O. Keohane \& Stanley Hoffmann, Conclusions: Community Politics and Institutional Change, in The Dynamics of European Integration 276, 278-82 (William Wallace ed., 1990). 
(a) The Court of Justice establishes the general criteria for determining whether or not a Community measure has direct effect in the national legal orders. 59

(b) The Court of Justice, applying these criteria, ultimately decides whether a particular Community measure does or does not have direct effect in the national legal orders. ${ }^{60}$

(c) The Court of Justice establishes the general test for determining whether a Member State, through its agencies or its courts, has given sufficient direct effect to a Community measure by making adequate remedies available to individuals for violation of the rights they derive from Community law. 61

(d) If need be, the Court of Justice ultimately decides whether under these criteria a Member State has given adequate effect to Community law in a given case. ${ }^{62}$

(e) If a Member State court is uncertain whether a Community measure is directly effective, or whether the State has given the measure adequate direct effect, it must seek a preliminary ruling from the Court of Justice on that question and respect the ruling it receives. ${ }^{63}$

(f) Not only are regulations of the Council and Commission (which EC Treaty Article 189 describes as "directly applicable"64) capable of having direct effect, but so are: (i) Treaty articles (which the Treaty does not describe in those terms ${ }^{65}$ ), (ii) Council and Commission directives (which Article 189 actually implies are not "directly applicable" and which, by definition, would seem to require further Member State implementation ${ }^{66}$ ), and (iii) Council and Commission decisions (which the

59. See Case 26/62, Van Gend en Loos v. Nederlandse Administratie der Belastingen, 1963 E.C.R. 1, 13, [1963] 2 C.M.L.R. 105, 130-31.

60. See Case 41/74, Van Duyn v. Home Office, 1974 E.C.R. 1337, 1342 [1975] 1 C.M.L.R. 1, 16.

61. See Case 8/81, Becker v. Finanzamt Mūnster-Innenstadt, 1982 E.C.R. 53, 65-66 [1982] 1 C.M.L.R. 499, 512.

62. The Court, it should be made clear, does not actually pass on the validity of any particular Member State measure and certainly never invalidates a Member State measure as such. However, it may determine whether the type of remedy available in the Member States is adequate for Community law purposes.

63. See Case 9/70, Franz Grad v. Finanzamt Traunstein, 1970 E.C.R. 825, [1971] 1 C.M.L.R. 1 (upholding direct applicability of EC law regarding tariff); see also Case 41/74, Yvonne van Duyn v. Home Office, 1974 E.C.R. 1337 (directing member state to protect EC laws on freedom of movement for workers); Case 20/70, Transports Lesage \& Cie v. Hauptzollamt Freibrug, 1970 E.C.R. 861 (directing member states to allow its nationals to invoke rights protected by EC turnover tax).

64. "A regulation shall have general application. It shall be binding in its entirety and directly applicable in all Member States." EC Treaty art. 189.

.65. "Member States shall take all appropriate measures, whether general or particular, to ensure fulfillment of the obligations arising out of this Treaty.... They shall facilitate the achievement of the Community's tasks." Id. art. 5.

66. "A directive shall be binding, as to the result to be achieved, upon each Member State to which it is addressed, but shall leave to the national authorities the choice of form 
Treaty simply calls "binding"67). Even a directive which has not been fully implemented by a Member State on a timely basis is capable of having direct effect in favor of private parties as of the deadline by which the State should have implemented it. 68

(g) Private parties are entitled to assert the rights that Community law measures confer upon them, not only against Member States (via a socalled "vertical direct effect"), but also against other private parties (via a "horizontal direct effect"), whenever those measures are relevant in otherwise purely private litigation taking place in national courts. ${ }^{69}$ An exception to the principle of horizontal direct effect only arises in the case of a directive which a Member State has failed to implement by the prescribed deadline; even then, however, a national court is required to interpret national law, whenever it can possibly do so, in such a way as to give horizontal direct effect to unimplemented directives. ${ }^{70}$

(h) If a Member State fails to implement Community law adequately, a person to whom that failure causes injury is entitled, as a matter of Community law, to recover damages from the State in the courts of that State for the relevant losses.71

The Court of Justice has likewise given a maximalist reading to the principle of supremacy, interpreting it in an equally uncompromising spirit. Thus, the Court eventually arrived, in supremacy's name, at the following specific propositions:

(a) In the event of conflict, Community law measures prevail over national measures irrespective of the sequence in which they were enacted. ${ }^{72}$

(b) For supremacy purposes, Community law measures include not only the Treaties, but also secondary legislation and individual decisions

and methods." Id. art. 189; see also Case 9/70, Grad v. Finanzamt Traunstein, 1970 E.C.R. 825, 833, [1971] I C.M.L.R. 1, 22.

67. "A decision shall be binding in its entirety upon those to whom it is addressed." EC Treaty art. 189.

68. See Case 8/81, Becker v. Finanzamt Münster-Innenstadt, 1982 E.C.R. 53, 63, [1982] 1 C.M.L.R. 499, 512.

69. See Case 43/75, Defrenne v. Société Anonyme Belge de Navigation Aérienne Sabena, 1976 E.C.R. 455, 465, 2 C.M.L.R. 98, 129 [1976]. The Court in Defrenne specificaily noted the applicability of Article 119 to establishments or services, "whether private or public." Id. at 40 .

70. See Case C-106/89, Marleasing SA v. La Comercial Internacional de Alimentacion SA, 1990 E.C.R. I-4135, 4160, [1992] 1 C.M.L.R. 305322.

71. See Case C-6, 9/90, Francovich v. Italy, 1991 E.C.R. - (Nov. 19, 1991), 2 C.M.L.R. 66, 113-14 (1993).

72. See Case 106/77, Amministrazione delle Finanze dello Stato v. Simmenthal S.p.A. (II), 1978 E.C.R. 629, 634, [1978] 3 C.M.L.R. 263, 284 (holding EC law invalidates contrary national law); see also Case 6/64, Costa v. Ente Nazionale Per L'Energia Elettrica (ENEL), 1964 E.C.R. 585, 593-94, [1964] I C.M.L.R. 425, 436 (Treaty law cannot be overridden by national constitutional or statutory law). 
issued by the Council and Commission. ${ }^{73}$ They also include general principles of law, which it is the province of the Court of Justice itself to identify, as well as Court of Justice rulings in individual cases. ${ }^{74}$

(c) Again for supremacy purposes, national measures are deemed to include not only primary and secondary legislation and administrative acts, but also national constitutional provisions. ${ }^{75}$

(d) National courts may not examine the validity of Community measures under national law, not even when the claim is that they violate the fundamental civil, political, and human rights enshrined in the national Constitution. ${ }^{76}$

(e) If a national court believes that a Community measure violates a higher legal norm of the Community (such as the Treaty or a general principle of law recognized by the Court of Justice, including human rights), it may only refer the question of the measure's validity to the Court of Justice for a preliminary ruling, and then follow that ruling. It may not on its own refuse to give effect to the Community measure. ${ }^{77}$

(f) Although national law may generally deny courts the right to review the legality of certain legal instruments (for example, statutes enacted by the national legislature), the courts must nevertheless entertain legal challenges to the application of those acts where the challenge is based on Community law. ${ }^{78}$

(g) National courts are required to give immediate effect to Community measures that have direct effect, and they may not postpone doing so on account of special procedures or traditions that they would ordinarily have to follow before denying effect to otherwise analogous national law. ${ }^{79}$

(h) National courts must make available to litigants who assert individual claims based on Community law all the legal remedies, including forms of provisional relief, that they ordinarily make available to litigants asserting other legal claims, and those remedies must in any event afford a minimally effective means of asserting those claims. ${ }^{80}$

73. See Case $87 / 75$, Conceria Daniele Bresciani v. Amministrazione Italiana delle Finanze, 1976 E.C.R. 129, 142, [1976] 2 C.M.L.R. 62, 79.

74. See Case 4/73, Nold v. Commission, 1974 E.C.R. 491, 502, [1974] 2 C.M.L.R. 338, 354-55.

75. See Case 11/70, Internationale Handelsgesellschaft v. Einführ-und Vorratsstelle für Getreide und Futtermittel, 1970 E.C.R. 1125, 1131, [1972] 10 C.M.L.R. 255, 282.

76. See id.

77. See Case 314/85, Firma Foto-Frost v. Hauptzollamt Lübeck-Ost, 1987 E.C.R. 4225, 4231 [1988] 3 C.M.L.R. 57, 79.

78. See Case 213/89, Regina v. Secretary of State for Transport ex Parte Factortame Ltd., 1990 E.C.R. I-2433, 2475, [1990] 3 C.M.L.R. 1.

79. See Case 314/85, Firma Foto-Frost, 1987 E.C.R. 4225; see also Case 106/77, Amministrazione delle Finanze dello Stato v. Simmenthal S.p.A. (II), 1978 E.C.R. 629, 639-40, [1978] 3 C.M.L.R. 263, 284.

80. See Case 213/89, Factortame [1990]; Case 222/86, UNECTEF v. Heylens, 1987 E.C.R. 4097, 4117, [1989] 1 C.M.L.R. 901, 913. See generally Koen Lenaerts, Some 
The Court of Justice has thus taken virtually every opportunity that presented itself to enhance the normative supremacy and effectiveness of Community law in the national legal orders. The same reasoning that brought the Court to its supranationalist doctrines appears to have caused the Court to apply them expansively. The Court's purpose, as it quite candidly conceded, ${ }^{81}$ was to establish all those constitutional premises that it considered necessary in order for Community policy, once made by the Community institutions, to be fully effective in the Member States. Whatever one may think of the Court's pronouncements as readings of the EC Treaty or as federalist policy, they do in fact unmistakably strengthen the force and effect of Community law. It is difficult to find a clearer example of instrumentalist judicial decision-making.

If the Member States largely accepted the Court's supranationalist claims, this is because they originally retained ultimate control over the Community's legislative process. ${ }^{82}$ The framers of the EC Treaty had entrusted the Community's legislative powers chiefly to a Council of Ministers in which representatives of the Member States could unapologetically express and vote the political interests. of the States they represented. ${ }^{83}$ Moreover, by virtue of a combination of Treaty provisions ${ }^{84}$ and legislative tradition, ${ }^{85}$ the determined opposition of any one Member State to a measure would cause the measure to fail. Thus, while advocates of European integration drew satisfaction from the normative aspects of Community federalism (notably direct applicability, direct effect, and supremacy), advocates of Member State sovereignty took comfort in the

Thoughts About the Interaction Between Judges and Politicians, 1992 U. Chi. Legal F. 93, 99-104.

81. See generally Lenaerts, supra note 80 , at 98-99 (citing, in particular, Case 26/62, Van Gend en Loos v. Nederlandse Administratie der Belastingen, 1963 E.C.R. 1, [1963] 2 C.M.L.R. 105)).

82. See Joseph Weiler, The Community System: The Dual Character of Supranationalism, 1 Y.B. Eur. L. 267, 286-88 (1982) ("The Court's reasoning that supremacy was enshrined in the Treaty was contested by the governments of Member States. ... Acceptance of this view amounts in effect to a quiet revolution in the legal order of the Member States."). The challenges that Member State courts mounted to the Court's claims focused on very particular issues. Thus, for example, the German and Italian Constitutional Courts have not yet categorically abandoned the right to test Community measures by fundamental rights provisions of the national constitutions.

83. See EC Treaty art. 146.

84. The Council's use of its most wide-ranging powers (notably harmonization and implied powers) originally required a unanimous vote, rather than either a simple or qualified majority of votes. The Single European Act introduced the possibility of harmonization by qualified majority vote under Article 100a. See EC Treaty art. 100a (as amended 1987).

85. In 1966, the then six Member State governments issued a statement known as the Luxembourg Accord, dealing with the situation in which a State believes that Community action about to be taken by majority vote would impair its vital interests. Though the Accord was somewhat ambiguous, it was commonly invoked until the 1980s as the basis for a single Member State "political" veto. On the Luxembourg Accord and its apparent demise, see Bermann et al., supra note 13, at 54-55. 
special composition and voting procedures of the Council of Ministers. In fact the Court's heightening of the normative stakes of Community action probably caused the States to guard their political prerogatives all the more jealously.

2. New Elements in Community Federalism. - While the Court's federalist doctrines, on the one hand, and the States' preponderance in the Community legislative process, on the other, had produced something of a balance of power, other forces were working to disturb that balance. I have already referred to changes in the legislative process of the Community-notably the shift away from unanimous and toward qualified majority voting - that lessened the States' opportunities to prevent legislation from being adopted over their objections. I describe the political significance of majority voting in greater detail later in this section. ${ }^{86}$ However, even before the shift to majority voting, further doctrinal developmentsdevelopments that were less visible than the doctrines of direct applicability, direct effect, and supremacy, but were likewise attributable to the Court-had effectively enlarged the arena of Community action. These forces together heightened the political vulnerability of the Member States vis-à-vis the Community and thus helped generate the impetus for subsidiarity.

a. Widening the Community Terrain. - The Court's early preoccupation with the relationship between Community and Member State norms tended to obscure other less obvious and more gradual jurisprudential developments in European federalism, all of which had the effect of expanding the Community's legislative presence. These developments pertained to (1) the enumeration of powers conferred on the Community by the Member States, (2) the extent to which the powers conferred on the Community belonged to it exclusively, and (3) the breadth or narrowness with which grants of power to the Community were to be construed. It is curious but not surprising that questions such as these, which had long dominated U.S. federalism debates familiar both to the Community's founders and the Court of Justice, took an apparent back seat in the Community context to the doctrines of direct applicability, direct effect, and supremacy. The architects of the Community, cognizant of the fact that the Community itself was the product of a treaty, and that the Member States were all mature nation-states in their own right, accepted an international law paradigm as the right one for their purposes. Within such a paradigm, questions of the direct applicability, direct effect, and supremacy of Community law understandably loomed large.

The framers of a federal constitution generally work in a different paradigm. They ask blunt questions about allocations of power, including questions about the enumeration of federal powers, preemption of state law and implied powers. Precisely because the EC Treaty as such was conceived as an international agreement, and only later came to be 
viewed as a constitutional document, its answers to these central federalism questions proved largely inadequate. The Treaty spoke very imprecisely about the enumeration problem, very puzzlingly about implied powers, and not at all about preemption. As and when the Court of Justice faced these questions, as its own supranationalist jurisprudence ensured it one day would, it brought to bear much the same teleological method of interpretation that it had initially employed in establishing the direct applicability, direct effect, and supremacy doctrines.

i. The Enumeration of Community Powers. - Difficult as it may now be to believe, the founders of the Community appear to have expected the Community institutions to intervene only in very specific ways in the Member State economies. Leaving aside certain spheres that they intended the Community to govern comprehensively (e.g., external commercial relations, interstate tariffs and customs, regulation of agricultural markets, and competition policy), their understanding was that the institutions would legislate only on the matters specifically identified in the Community treaties, ${ }^{87}$ and in doing so would be bound by the precise substantive and procedural conditions set out in the relevant Treaty article. ${ }^{88}$

Nevertheless, the EC Treaty contained the seeds of an expansive legislative practice. Legislation on the elimination of non-tariff barriers to the free movement of goods provides a good illustration. The relevant Treaty provisions (Articles 30 through 37 ) basically require the Member States to refrain from enacting or maintaining unjustifiable trade-impeding restrictions. By attributing direct effect to these provisions, the Court enabled-in fact directed-national courts to deny legal effect to Member State measures containing such restrictions. The negation of impermissible restraints on interstate trade of course powerfully echoes the Supreme Court's dormant commerce clause jurisprudence. ${ }^{89}$ At the same time, however, the Treaty also authorized the Commission and Council to enact "positive" legislation to facilitate the removal of nontariff barriers to trade. This affirmative authority derived chiefly from EC Treaty Article 100: "The Council shall ... issue directives for the approximation of such provisions laid down by law, regulations or administrative action in Member States as directly affect the establishment or functioning of the common market." Article 100 required such "harmonizing" directives to be adopted by the Council of Ministers unanimously, if at all,

87. In its seminal Van Gend en Loos judgment, Case 26/62, Van Gend en Loos v. Nederlandse Administratie der Belastingen, 1963 E.C.R. 1, 12, [1963] 2 C.M.L.R. 105, 129, the Court described the States as having ceded sovereignty "albeit in limited fields." Id.

88. See generally Auke Haagsma, The European Community's Environmental Policy: A Case-Study in Federalism, 12 Fordham Int'1 L.J. 311, 354-56 (1989); Lenaerts, supra note 80, at 123-25; see also Dewost, supra note 7, at 2.

89. Unlike the United States Supreme Court, however, the Court of Justice does not normally rule directly on the validity of Member State laws. However, it may and often does clearly indicate as a matter of law that State measures of a certain kind or description run afoul of the EC Treaty. See supra note 62. 
thus enabling even a single Member State to block a harmonization measure or cause it to be weakened.90

The claim that Article 100 established federal legislative jurisdiction over interstate commerce is actually an understatement. The theory behind the harmonization of Member State laws is that even rules purporting to regulate exclusively intrastate trade may nevertheless operate to make the common market less "common" and, to that extent, impede interstate commerce. ${ }^{91}$ Rather than rely exclusively on the Court to root out offensive State measures on a case by case basis (or to prompt national courts to do so on their own), the Council of Ministers could bring about a regulatory rapprochement of Member State rules by "directing" the States to modify their laws governing the domestic market in prescribed ways. Events proved that the Council would in fact use its positive harmonization powers liberally to impose certain regulatory minima or maxima on the States on a wide variety of subjects. ${ }^{92}$ As a result, once national legislation was modified to bring it into conformity with the relevant Community directive, that legislation reflected policy that had been made in Brussels, and did so even as applied to purely intrastate matters.

A constitution that allows federal authorities to prescribe state policy over purely intrastate trade, on the theory that national disparities may distort patterns of interstate trade, cannot seriously be regarded as "enumerating" the Community's legislative powers. ${ }^{93}$ Even a subject plainly reserved as such to the States (e.g., health, education, or public safety) is transformed into a Community matter to whatever extent the

90. The 1986 Single European Act (SEA) was later to relax the procedural rules for harmonization, by introducing qualified majority voting in the Council and permitting the use of regulations as well as directives. See infra notes 123-128 and accompanying text. Specifically, the SEA added Article 100 a to the EC Treaty: "The Council shall, acting by a qualified majority ... adopt the measures for the approximation of the provisions laid down by law, regulation or administrative action in Member States which have as their object the establishment and functioning of the internal market." EC Treaty art. 100a (as amended 1987). The introduction of qualified majority voting paved the way for easier passage of legislation because it allowed certain combinations of States to legislate over the others' objections and encouraged the Commission to formulate legislative proposals that fell short of universal acceptance.

91. See, e.g., Eurononsense, The Economist, Dec. 26, 1992, at 70 (descriptions of several intrastate regulations that suppress interstate commerce); see also David T. Keeling, The Free Movement of Goods in EEC Law: Basic Principles and Recent Developments in the Case Law of the Court of Justice of the European Communities, 26 Int'l Law. 467, 469, 471, 475 (1992); see generally Eric Stein et al,, European Trade, 1992: Fortress or Partnership?, 83 Am. Soc'y Int'l L. Proc. 332, 333 (1989).

92. See Pollution Directive Annulled, The Times (London), Aug. 21, 1991, at 31 (transcript of Case 300/89, Commission v. Council 1991 E.C.R. I-2867, 3 C.M.L.R. 359 (1993)); see, e.g., Council Directive 92/42, 1992 O.J. (L 167) 17 (on efficiency requirements for new hot-water boilers fired with liquid or gaseous fuels); Council Directive 93/15, 1993 O.J. (L 121) 20 (on the harmonization of the provisions relating to the placing on the market and supervision of explosives for civil uses).

93. An analogous observation could be, and has been, made about Congress' exercise of prescriptive jurisdiction under the Commerce Clause. 
federal political branches find that the cross-border mobility of goods (or, by parallel reasoning, workers, services, or capital) would be advanced by bringing the various national rules on the subject into closer alignment with each other. The theory, as one eminent expert pointed out, left "no nucleus of sovereignty that the Member States [could] invoke, as such, against the Community." ${ }^{4}$

A piece of Community legislation that brings the point home particularly forcefully is the 1985 Council Directive on Products Liability. ${ }^{95}$ The directive purported to harmonize the different products liability regimes of the Member States chiefly in order to create more uniform regulatory conditions for business and thereby promote "the establishment or functioning of the common market." 96 The Council thereby legislated on the subjects of civil liability and consumer protection, matters thought to lie well within the Member States' reserved powers. By this pattern of reasoning, Member State policies on virtually any subject could be harmonized, if need be even as applied to purely local transactions, on the theory that one or more of the factors of production would thereby be caused to move more freely across state borders. ${ }^{97}$

ii. Preemption of Member State Law. - Since the treaty drafters were not as attentive to the demarcation of federal and state powers as they might have been had they been drafting a modern federal constitution, it is not surprising that they also did not explicitly address the question of preemption. ${ }^{98}$ This too is not because the drafters were unaware that the grant to the Community of legislative power over a certain subject might have the effect of removing altogether state power to legislate on that subject. Even aside from the American experience, which was well known, the German Basic Law, itself less than ten years old at the time the EC Treaty was signed, had designated certain subjects as within the

94. Lenaerts, supra note 10 , at 220 . As another commentator has noted:

There is no residue of powers reserved to Member States. ... [Moreover], since Community legislation always prevails over national law, Community legislation, once adopted, can be amended only by the Community. So every piece of Community legislation creates pro tanto an area of exclusive Community legislative power. This is [especially] important ... because the treaties give the

Community such wide (non-exclusive) legislative powers.

John Temple Lang, The Development of European Community Constitutional Law, 25 Int'l Law. 455, 460 (1991).

95. Council Directive of July 25, 1985 on the Approximation of the Laws, Regulations and Administrative Provisions of the Member States Concerning Liability for Defective Products, Council Directive 85/374, 1985 O.J. (L 210) 29.

96. EC Treaty art. 100.

97. For a cogent description of this process of expansion of Community legislative power, see Weiler, supra note 20 , at $2438-41$. Weiler designates as "absorption" the process by which "the Community legislative authorities, in exercising substantive legislative powers bestowed on the Community, impinge on areas of Member State jurisdiction outside the Community's explicit competences." Id. at 2438; see also Everling, supra note 2 , at $1066-69$.

98. I am using the term preemption here narrowly to denote a decision by federal authorities to "occupy" a field to the exclusion of the states. 
exclusive domain of the federal government of Germany and others as within the concurrent jurisdiction of the federal government and the states. ${ }^{99}$ Preemption, however, is a quintessential federalism issue, and it did not fit into the framers' original international law paradigm. The very idea of preemption, in the sense of occupying the field to the exclusion of the States, posed a very basic threat to notions of state sovereignty.

The fact remains, however, that at least some of the Community's objectives simply could not be satisfactorily achieved unless the Community's power to act was exclusive. Thus, the Court of Justice readily concluded that an external tariff or commercial policy by its nature would not be truly common, as planned, ${ }^{100}$ unless it were exclusively federal, at least once the transitional period had ended. ${ }^{101}$ The case for preemption in these fields was so strong, it was treated as "constitutional" (in that the States were precluded from acting, irrespective of whether the Community institutions had by then taken any action at all), ${ }^{102}$ and not merely "legislative" (that is, foreclosing Member State action only insofar as specific Community legislation so stated or implied).

Although the Treaty likewise denominates the Community's agricultural policy as common, the case for constitutional preemption in that area was weaker. It was not reasonable to treat the States as having abandoned regulation of all agricultural sectors merely because they conferred power on the Council and Commission to enact comprehensive rules for the organization of the various markets as, and when, those institutions might choose to do so. The prevailing view, accordingly, is that once the Community adopts a common agricultural policy for a given market, the States lose their authority to regulate that market, ${ }^{103}$ but that until such time, they may continue to regulate it, provided of course they do not otherwise infringe upon the free movement of goods or other basic principles of the EG Treaty. ${ }^{104}$

99. The Grundgesetz went so far as to distinguish between powers that were "permanently" concurrent and others that were concurrent only until the federal government took action of some kind, at which time the matter passed into that government's exclusive domain. See Grundgesetz [Constitution] art. 72 (Germany).

100. "[T] he activities of the Community shall include ... the establishment of a common customs tariff and of a common commercial policy towards third countries." EC Treaty art. 3(b).

101. See Case 38/75, Nederlandse Spoorwegen v. Inspecteur der Invoerrechten en Accijnzen, 1975 E.C.R. 1439, 1449.

102. See Weiler, Transformation, supra note 20, at 2416-17 (using the term "exclusive" to denote competences reserved to the Community ab initio).

103. See Case 29/87, Dansk Denkavit v. Tuchtgerecht, Danish Ministry of Agriculture, 1988 E.C.R. 2965, 2988, [1990] 1 C.M.L.R 203, 214; Case 255/86, Commission v. Belgium, 1988 E.C.R. 693, 708 [1989] 3 C.M.L.R. 91, 101; Case 130/85, Re Wulro BV v. Tuchtgerecht Van de Stichting Scharreleiren-Controle, 1986 E.C.R. 2035, 2044, [1988] 1 C.M.L.R. 496, 503; see also G. Federico Mancini, The Making of a Constitution for Europe, 26 Common Mkt. L. Rev. 595, 603-04 (1989).

104. See Weiler, Transformation, supra note 20 , at 2417. Weiler confines use of the term "preemption" to matters not reserved to the Community ab initio. 
In most other areas, ${ }^{105}$ neither the language of the Treaty nor the specific nature of the sector addressed in a given section of the Treaty clearly signals the framers' intention. Under these circumstances, preemption can realistically only be what it has become in the United States, that is, essentially a question of statutory interpretation. ${ }^{106}$ The Court of Justice's "emerging doctrine of [legislative] preemption" has been described adequately elsewhere. ${ }^{107}$ Suffice it to say that the Court commonly finds that, in enacting a piece of legislation, the Council or Commission meant to regulate a matter comprehensively and to preclude the States from addressing it. ${ }^{108}$ Sometimes the Court has done so on a very meager showing of implied preclusion, that is, without much evidence that the Council had produced a comprehensive regulatory scheme whose purposes would be thwarted by continuing Member State interventions. ${ }^{109}$

The Court's hospitality to preemption claims may not always have been welcome in Member State circles, but it is surely not illogical. At least until the Single European Act, the bulk of the Community's legislative initiatives were predicated on the creation of a common market in which the factors of production move freely across state borders; they were not predicated on the necessity of prescribing one or another policy in a substantive field falling specifically within the Community's sphere of competence. Legislative preemption by definition favors the establishment of a harmonious regulatory environment throughout the territory of the Member States and therefore indirectly the commonness of the common market. In fact, the Court of Justice eventually ruled that, once the Community adopts a harmonization measure that specifically enough addresses a given public interest-such as environmental or consumer protection-the States may no longer invoke that interest to justify restrictions on trade under Article 36 and other EC Treaty exceptions to the principles of free movement. ${ }^{110}$

105. The one other area in which the Court addressed preemption in constitutional terms is competition policy. Here the Court concluded that while the States had to refrain from regulating business in terms of its anticompetitive effects on interstate Community trade, they could continue to regulate purely intrastate trade. See Case $14 / 68$, Wilhelm v. Bundeskartellamt, 1969 E.C.R. 1, 9-10, [1969] 1 C.M.L.R. 100, 118-20.

106. See infra notes $358-361$ and accompanying text.

107. See generally Eugene Cross, Pre-Emption of Member State Law in the European Economic Community: A Framework for Analysis, 30 Common Mkt. L. Rev. 447 (1992); M. Waelbroeck, The Emergent Doctrine of Community Pre-Emption: Consent and ReDelegation, in 2 Courts and Free Markets 548 (Terence Sandalow \& Eric Stein eds., 1982). 108. See, e.g., Case 111/76, Officier van Justitie v. Beert van den Hazel, 1977 E.C.R. 901, 909, [1980] 3 C.M.L.R. 12, 23; Case 148/78, Pubblico Ministero v. Ratti, 1979 E.C.R. 1629, 1636-37, [1980] 1 C.M.L.R. 96, 110-11.

109. See generally Renaud Dehousse \& Joseph H.H. Weiler, The Legal Dimension, in The Dynamics of European Integration, supra note 58, at 242, 255; Lenaerts, supra note 10 , at 224-30.

110. See, e.g., Case 28/84, Commission v. Germany, 1985 E.C.R. 3097, 3106-07, [1985-86 Transfer Binder] Common Mkt. Rep. (CCH) I 14,251 (1985); Case 120/78, 
Curiously, the case for legislative preemption is actually weaker when the Community pursues social and political objectives in their own right, as legitimate matters of Community concern. (This is, of course, more likely to be the case after the Single European Act and the Maastricht Treaty on European Union.) In order for the Community to improve labor standards, or raise the level of environmental or consumer protection, for example, its regulatory demands need not be preemptive, though the Community may of course have reasons for choosing to "occupy" one or another specific field. On the contrary, the Community might fully satisfy its regulatory objectives by establishing a minimum level of protection that is mandatory on the States, while leaving the States free to adopt a higher or broader level of protection. ${ }^{111}$ In the event the States do so, the Community simply needs to ensure that the added protection does not come at a price that is excessive either in terms of the Community's other policy objectives or in terms of its core commitment to the free movement of goods, persons, services, or capital.

The Court's preemption jurisprudence is thus somewhat paradoxical. The Treaty's initial failure to provide the Community institutions with an independent policy basis for legislating on a large number of subject matters caused the institutions to approach those matters indirectly, through harmonization measures ostensibly designed to reduce or eliminate regulatory differences and thereby facilitate the internal market. Thus, although the Member States were not ready to cede prescriptive jurisdiction over these subjects to the Community, they nevertheless found the Community asserting a "common market" interest in them and advancing an even stronger claim to have its legislation interpreted as preemptive. It is thus no coincidence that the Single European Act, with its deliberate extension of Community competence to new substantive areas, also brought express language of non-preemption into the Treaty for the first time. Unsurprisingly, the SEA's new provisions on the environment included language of this sort, ${ }^{112}$ as did its provisions on worker health and safety; ${ }^{113}$ these are subjects over which certain Member States

Rewe-Zentrale AG v. Bundesmonopolverwaltung für Branntwein (Cassis de Dijon), 1979 E.C.R. 649, 656-58, [1979] 3 C.M.L.R. 494.

111. See, e.g., Case 53/86, Officer van Justitie v. L. Romkes, 1987 E.C.R. 2691, 2696, 2702, [1988] 3 C.M.L.R. 126 (regarding fishing regulations); Case 4/75, Rewe Zentralfinanz $\mathrm{GmbH}$ v. Landwirtschaftskammer, 1975 E.C.R. 843, 847, [1977] 1 C.M.L.R. 599 (regarding produce sanitation measures).

112. See EC Treaty art. 130t (as amended 1987) ("The protective measures adopted in common pursuant to Article $130 \mathrm{~S}$ [on the environment] shall not prevent any Member State from maintaining or introducing more stringent protective measures compatible with this Treaty.").

113. See EC Treaty art. 118a(3) (as amended 1987) ("The provisions adopted pursuant to this Article shall not prevent any Member State from maintaining or introducing more stringent measures for the protection of working conditions compatible with this Treaty."). 
in negotiating the SEA had insisted on the right to maintain or enact standards more protective than those that the Community might adopt.

By the same token, the Maastricht Treaty on European Union should have attached comparable non-preemption language to its provisions enlarging the Community's competences (to include, for example, consumer protection), or should possibly have raised non-preemption to the level of a general Community law presumption. That the TEU did not do so is probably due to the fact that it did, through its own Article B and the new Article 3b that it added to the EG Treaty, ${ }_{114}$ make subsidiarity a general principle of Community law. Under subsidiarity, arguably, the institutions should not preempt (or be deemed to have preempted) Member State action over a subject unless they must do so in order to achieve the Community's objectives. ${ }^{115}$

iii. The Elasticity of Community Powers. - Unlike preemption, the question of implied powers was addressed directly by the Treaty and in early decisions of the Court of Justice. Based on the implied powers language of Article 235, ${ }^{116}$ the Court might have been expected to permit the Community institutions to exercise powers not expressly granted them only when the exercise of such powers was shown to be necessary for achieving a stated Community purpose. This would have been consistent not only with the Article's wording, but more generally with the notion that the EG Treaty had effected a carefully limited transfer of sovereignty from the Member States to the Community. In scrutinizing the institutions' every claim to authority not expressly vested in them by the Treaty, the Court might actually have underscored that the Community was to be a polity of limited powers-limited not only because the States made only a "partial" transfer of sovereignty, but also because that transfer took the form of carefully crafted treaty provisions, each with its own very precise combination of substantive and procedural conditions. However, a judicial policy of this sort would have disserved an objective that was ultimately dearer to the Court, namely maximizing the effectiveness of Community law within the Community's emerging political and economic system. The instrumentalist reasoning that drove the Court's more patently federalist doctrines of direct applicability, direct effect, and supremacy also militated in favor of a liberal understanding of implied powers.

114. See supra note 41 and accompanying text.

115. A presumption of non-preemption is actually more closely akin to the principle of proportionality than the principle of subsidiarity, see infra notes 157-161 and accompanying text, but it is certainly consistent with both.

116. EC Treaty article 235 states:

If action by the Community should prove necessary to attain, in the course of the operation of the common market, one of the objectives of the Community and this Treaty has not provided the necessary powers, the Council shall, acting unanimously on a proposal from the Commission and after consulting the European Parliament, take the appropriate measures.

EC Treaty art. 235. 
In point of fact, while the Court commonly examines whether the EC Treaty independently gives the Community sufficient powers for achieving a stated objective for which the institutions are claiming implied powers under Article 235, it rarely considers whether the powers claimed are in fact ones that are strictly necessary. ${ }^{117}$ What is more, the Court frequently finesses altogether the question of whether the textual conditions for implied powers under Article 235 are met, and instead gives the express powers of the institutions under the Treaty a sufficiently broad and liberal reading to meet the Community's needs. ${ }^{118}$ A generous interpretation of the institutions' express powers (or, if one prefers, a readiness to infer powers from express treaty provisions) can obviate the need for recourse to Article 235 as an independent basis for implied powers. It is also a less conspicuous way to resolve jurisdictional doubts in favor of the Community.

b. The Community's New Institutional Dynamics. - The previous section shows that the Community is the product of a succession of distinct constitutional developments. Because the Community grew out of an international agreement that at the time was of less than certain legal force and effect in the Member States, the Court of Justice understandably saw laying the normative foundations of legal integration as a matter of first priority. The result, as we have seen, ${ }^{119}$ was a powerful doctrinal edifice based on the direct applicability, but even more so on the direct effect and supremacy of Community law. Intrinsically expansive of Community authority, these principles went on to receive a maximalist construction, thus hastening the EC Treaty's transformation from an international treaty into a political constitution. ${ }^{120}$ Furthermore, the Member States accepted this massive dose of supranationalism because the Community's political processes still allowed them to safeguard their vital interests.121 This balance may have seemed sufficiently stable to permit the Court to address the next generation of more squarely constitutional questions in ways that likewise favored the Community's assertions. The result was a further legal empowerment of the Community through a relaxed attitude toward enumeration, a receptiveness to Community preemption, and a generosity toward implied powers. ${ }^{122}$

The Single European Act (SEA), however, began to loosen the Member States' grip on the Community legislative process. Along with the

117. See generally Haagsma, supra note 88 , at 327 .

118. See, e.g., Case $8 / 55$, Fédération Charbonnière de Belgique v. High Authority of the European Coal and Steel Community (Fédéchar), 1954-1956 E.C.R. 245, 259 (finding that the High Commission had the authority necessary to establish new pricing schedules for Belgian coal).

119. See supra notes $56-81$ and accompanying text.

120. Joseph Weiler's use of the term "transformation" is particularly apt in this context. See Weiler, Transformation, supra note 20, at 2405-07.

121. See supra notes $82-85$ and accompanying text.

122. See supra notes $87-118$ and accompanying text. 
apparent demise of the Luxembourg Accord, ${ }^{123}$ the advent in the SEA of qualified majority voting in the Council of Ministers ${ }^{124}$ threatened to deprive Member States of the political and legislative leverage to which they had become accustomed. It is interesting that the impact of qualified majority voting on the Community's federalism balance did not come in for very close examination at the time. Most likely this is because the Commission believed, and very largely succeeded in convincing the Member States, that completion of the internal market by the end of 1992 was the Community's paramount objective and that substituting qualified majority voting for unanimous voting in the Council was vital to achieving it. ${ }^{125}$ The 1992 Program in fact offered the Member States and most of their constituencies a goal around which they rallied with an enthusiasm and a degree of consensus that they had not exhibited since the 1950s.

This is not to suggest that the Member States were insensitive to the change in equilibrium. Even under the SEA, they reserved unanimous voting for the matters about which they felt most keenly. ${ }^{126}$ The SEA also made provision for a new "derogation" procedure allowing Member States to escape the effects of harmonizing legislation adopted by a qualified majority under Article 100a, ${ }^{127}$ if they could show the necessary hardship and the Commission could be convinced of it. ${ }^{128}$ In addition, as noted, the language of non-preemption and subsidiarity made its first, though still quite limited, appearance on the face of the Treaty through the SEA. 129 This too was a sure sign of misgivings, at least in some quarters. Nevertheless, the Member States had made easier passage of "single market" legislation their top political priority and accepted voting by qualified majority as a sure and reasonably safe means to that end.

The intergovernmental conferences on economic and monetary union (EMU) and on political union that opened in Rome in 1990 proceeded in a climate of basic satisfaction with the Community's progress toward 1992. With the recently adopted European Social Charter ${ }^{130}$ and the detailed Delors Plan on Economic and Monetary Union ${ }^{131}$ before

123. See supra note 85 and accompanying text.

124. See supra note 38 and accompanying text.

125. See generally Metcalfe, supra note 2, at 8-10.

126. The SEA, for example, left unchanged the rule of unanimity for harmonization of indirect taxation.

127. See supra note 84 and accompanying text.

128. See EC Treaty art. 100a(4) (as amended 1987). The provision reads:

If, after the adoption of a harmonization measure by the Council acting by a qualified majority, a Member State deems it necessary to apply national provisions on grounds of major needs . . . it shall notify the Commission of these provisions.

The Commission shall confirm the provisions involved after having verified that they are not a means of arbitrary discrimination or a disguised restriction on trade between Member States.

Id.

129. See supra notes $37,112,113$.

130. See supra note 49 .

131. See supra note 39 . 
them, the Member State representatives were virtually certain to propose extensive Treaty amendments allowing the Community to move aggressively on the social policy front and on economic and monetary union; only the exact terms and modalities needed to be debated and eventually resolved, as in the end they were at Maastricht. At the same time, a large number of other subjects-health, consumer protection, education, culture, tourism, energy, immigration, anti-drug and anti-terrorism programs, among others-were being pressed upon the negotiators as natural "new" chapters in an amended Treaty. ${ }^{132}$ In addition, the "completion of the internal market," called for by the SEA, was clearly unfinished business and would still remain so at the end of 1992. The possibilities for harmonizing new and existing regulatory measures in the interest of a more "complete" internal market were, and are of course, endless. All told, the prospects for legislative activism in the post-1992 Community were grand.

The conferees at Rome and Maastricht understandably devoted much of their time to discussing the procedures by which decisions affecting economic union, social policy, and the Community's new competences would be made, which of course also helps explain the enormous bulk of the Maastricht Treaty and its protocols. But though special voting precautions would be taken on the politically most sensitive issues, a broad retreat from qualified majority voting was never in the picture. Thus, whatever the eventual outcome on the many difficult points dividing them, the Member States were poised for a quantum widening of the Community terrain without any significant narrowing of the decisional rules. In fact, the Maastricht Treaty provides still wider scope for qualified majority voting in the Council at the expense of unanimous voting, ${ }^{133}$ while at the same time expanding the use of parliamentary cooperation in the legislative process of the Community and introducing a system of parliamentary co-decision in selected areas. ${ }^{134}$

132. On the expansion of Community competences, see Renaud Dehousse, Integration v. Regulation? On the Dynamics of Regulation in the European Community, 30 J. Common Mkt. Stud. 383, 384-86 (1992).

133. The Maastricht Treaty, for example, brings environmental and consumer protection, public health, education and social policy under the regime of qualified majority voting. See EC Treaty arts. 118a(2), 126, 129, 129a, 130s (as amended 1992); Agreement on Social Policy, supra note 49.

134. Parliamentary cooperation, first introduced into the Community under the SEA, gives Parliament the right to propose amendments to legislation provisionally adopted by the Council (in the form of a "common position"). See supra note 34 and accompanying text. It is recodified under the TEU as EC Treaty art. 189c.

EC Treaty art. 189b, added by the TEU, provides for a further legislative process called parliamentary co-decision. Parliamentary co-decision is a new and complex legislative procedure whose essential purpose is to give Parliament a kind of legislative veto power. An increase in the European Parliament's legislative powers was among the most prominent agenda items of the Rome intergovernmental conference on political union, just as it had been for the 1985 Luxembourg intergovernmental conference that produced the Single European Act. 
c. The Maastricht Environment. - If further inducements toward subsidiarity were needed, the political and economic climate in which the Member State conferees were gathering in 1990 to discuss further European union supplied them. For the first time since the "Europessimism" of the 1970s and very early 1980s, the Member States governments found themselves in deep anxiety over the condition of their economies and doubtful of the Community's capacity to rescue them from it. In fact, in many circles the Community enterprise itself provided a focus for the kind of scapegoating that national economic downturns can so easily provoke. ${ }^{135}$

In addition to an obstinate economic recession, the Member States also faced the prospect of a significant enlargement of the Community. Although the most imminent widening stood to bring relatively prosperous States-Austria, Finland, Norway, Sweden, and Switzerland-into the Community, the very increase in membership suggested that political agreement on common solutions would in the future only become more difficult to produce. In fact, however, the crumbling of states to the East (and the resulting integration into the Community of the impoverished former East Germany) reminded the Member States that the Community's manifest destiny did not lie only in the direction of the EFTA countries. The upheavals in Central and Eastern Europe augured not only another quantum enlargement of the Community, but eventually a very different mix of Members as well.

At a constitutional moment like this-with the supranationalist stakes long since established, the terrain for Community action widened and still widening, and the rules of decision-making relaxed-subsidiarity was at its most beguiling. Other factors-the influx of immigrants, the loss of confidence in an effective common European foreign policy, and regional demands within the Member States themselves-only heightened the subsidiarity impulse. But, although it is the constitution-makers' task to shape political impulses like subsidiarity into workable and durable instruments, the established instruments of federalism all missed the point.

The principle of subsidiarity does not, for example, seek to challenge the direct applicability, direct effect, or supremacy of Community law, or any of the prerogatives of the Court of Justice. It does not quarrel with

135. See Roland Gribben, Walters Accepts Some Blame for "Mild" Recession, The Daily Telegraph (London), Sept. 28, 1990, at 23; see also Enrique Tessieri, Industry Pride Sinks to an All-Time Low, Fin. Times, Dec. 18, 1989, at 16. 
the notion of implied powers ${ }^{136}$ or with Community preemption, ${ }^{137}$ provided the use is fair. Since subsidiarity deals with the exercise of legislative self-restraint within the constitutional sphere of federal power, enumerating federal powers as such does not help; the Maastricht Treaty predictably reaffirmed the enumeration principle, requiring the Community to "act within the limits of the powers conferred upon it by this Treaty and of the objectives assigned to it therein." 138 Subsidiarity asks a quite different question, namely whether the powers that do fall within the Community sphere should in fact be exercised. By the same token, expressly reserving to the States all powers not delegated to the federal government, as does the U.S. Tenth Amendment, ${ }^{139}$ simply begs the question. Subsidiarity challenges none of these notions, but it is not satisfied by any of them either. It starts off precisely where the conventional tools of constitutional federalism leave off and where legislative politics is ordinarily thought to begin.

\section{Putting Subsidiartiy into Practice}

Subsidiarity may function in at least four different ways. Its first and, I would suggest, most important function is legislative. Arguably, each participant in the legislative process of the Community-the Commission in proposing (and in some cases issuing) a rule, the Parliament and other bodies $^{140}$ in expressing an opinion on a proposed rule, and the Council in adopting a rule-can determine whether the measure comports with the principle of subsidiarity before, respectively, proposing, commenting on, or adopting it. ${ }^{141}$ It can likewise disfavor, oppose, or reject the measure, as the case may be, if the measure fails to do so. Second, any legislative doctrine can also perform an interpretive function. If the Council or Commission may be presumed to observe the principle of subsidiarity in adopting legislation, then those who are called on to interpret that legislation-including the Court of Justice but more commonly the various Member State officials who administer and enforce it-should, in case of

136. The TEU art. $F(3)$ actually provides: "The Union shall provide itself with the means necessary to attain its objectives and carry through its policies." The European Council, meeting at Edinburgh, stated that the Community's use of Article 235 powers was itself, however, also subject to the principle of subsidiarity. See Edinburgh Conclusions, supra note 11 , at 4 .

137. Virtually all "official" definitions of subsidiarity stress that it applies only in areas of concurrent Member State and Community competence. See supra notes 9, 35, 41 and accompanying text.

138. TEU art. G(5).

139. The Tenth Amendment to the U.S. Constitution reads: "The powers not delegated to the United States by the Constitution, nor prohibited by it to the States, are reserved to the States respectively, or to the people." U.S. Const. amend. X.

140. These would include various management, regulatory and advisory committees attached to the Council, as well as the Economic and Social Committee.

141. See generally The Principle of Subsidiarity: Communication of the Commission to the Council and the European Parliament, SEC (92) 1990 final, at 13, I IV (Oct. 27, 1992). 
doubt, favor the interpretation that most respects that principle. Third, compliance with the principle of subsidiarity may be regarded as an element of the legality of Community action. Thus, any measure infringing upon the principle would be invalid on that ground alone. However, even if subsidiarity is justiciable, its enforcement is reserved to the Community judiciary, ${ }_{142}$ since Member State courts cannot themselves rule on the validity of a Community measure. ${ }^{143}$

Finally, the principle of subsidiarity can perform a confidence-building function by reassuring the constituent states, and notably the regions and other subcommunities within the states, that their distinctiveness will be respected at the European Community level. ${ }^{144}$ As shown by the evolution of Community federalism traced in Part I of this Article, subsidiarity is in fact playing, or being asked to play, this role today. Of course, absent some evidence that subsidiarity actually exerts legislative, interpretive, or adjudicatory influence, it cannot credibly perform its confidence-building function either. On the other hand, if subsidiarity does manage to perform this function, it can enhance the legitimacy of all European Community measures and of the Community itself. The difficulty of operationalizing subsidiarity does not in the least lessen its importance.

If, as seems evident, subsidiarity addresses issues that are ordinarily relegated to the political realm, then subsidiarity's central function must be its legislative one. This means in turn that each participant in the Community's legislative process should, on the occasion assigned to it by that process, determine whether the measure under consideration meets the test of subsidiarity, and act on the measure accordingly. What I call the legislative function of subsidiarity in fact figures prominently in the official subsidiarity guidelines adopted by the European Council ${ }^{145}$ at its

142. The Court of Justice of the European Communities is the Community's principal judicial institution. See supra note 13. The only other Community court is a Court of First Instance (CFI), created in 1988 to exercise judicial power over a limited category of cases in first instance, chiefly over staff and competition law cases. The CFI's jurisdiction was extended by the Council in June 1993 to cover all other direct actions (except antidumping cases) brought by natural or legal persons. See Extending the Jurisdiction of the Court of First Instance, 18 Eur. L. Rev. 270 (1993). It still lacks jurisdiction over actions brought by Member States or by the EC institutions, and it cannot entertain preliminary references.

143. See Case 314/85, Firma Foto-Frost v. Hauptzollamt Lübeck-Ost, 1987 E.C.R. 4199, 4220, [1988] 3 C.M.L.R. 57, 71.

144. See supra notes $25-29$ and accompanying text.

145. The European Council (as contrasted with the Council of Ministers of the Community) consists of the heads of state or of government of the Member States when meeting as an intergovernmental political grouping rather than as the Community's chief legislative organ. Its meetings, held at least twice a year, are commonly characterized as "summits." On the European Council generally, see Bermann et al., supra note 13, at 12-13, 55-57. 
Edinburgh Summit in December 1992..$^{146}$

\section{A. The European Council Guidelines}

The European Council at Edinburgh set for itself the task, among others, ${ }^{147}$ of clarifying how subsidiarity would be secured within the Community system. Evoking subsidiarity's legislative function, the Council affirmed that the principle was binding on all of the Community's political institutions, though not meant to alter their respective functions or to affect the institutional balance between them. ${ }^{148}$ With respect to its adjudicatory function, the Council specified that subsidiarity was not intended to have direct effect in national courts, ${ }^{149}$ but that it furnished a proper ground for a direct challenge to Community measures in the Court of Justice. ${ }^{150}$ Finally, the European Council sought by the tenor of its remarks on subsidiarity to reassure the Member States and their various subcommunities that the post-1992 Community would genuinely respect their separate interests and capacities. This seemed especially necessary in light of the Danes' rejection by referendum of the Maastricht Treaty151 and the closeness of the French vote, ${ }^{152}$ and in anticipation of political

146. Two months earlier, the European Council had resolved at its Birmingham Summit that "[a]ction at the Community level should happen only when proper and necessary," and that recognition of a principle of subsidiarity "is essential if the Community is to develop with the support of its citizens." European Council in Birmingham, Conclusions of the Presidency, Oct. 16, 1992, Europe: Agence Internationale d'Information pour la Presse, Oct. 18, 1992, at 3. The European Council announced at Birmingham its intention to issue guidelines at the Edinburgh Summit on the practice of subsidiarity. See id.

147. Among the European Council's most pressing tasks at Edinburgh was agreeing upon modifications to the Maastricht Treaty or its protocols that would cause the Danish electorate to support ratification of the Treaty in a second referendum following its rejection of the Treaty in a first referendum.

148. See Edinburgh Conclusions, supra note 11, at 3 .

149. See id. at 4. The absence of direct effect means that individual litigants do not have the right to invoke the principle of subsidiarity in national court to avoid the application of an otherwise relevant Community law measure on the ground that it violates that principle. See infra notes 238-241 and accompanying text.

150. See Edinburgh Conclusions, supra note 11, at 4. A direct challenge to a Community measure may be brought in the Court of Justice under EC Treaty Article 173. Article 173 contemplates legal challenges to binding acts of the institutions and confers standing for this purpose on the Member States and the institutions, as well as on private parties seeking to challenge decisions addressed to them or otherwise of direct and individual concern to them. Such actions must in principle be brought within two months of publication of the measure challenged.

151. Danish voters voted to reject the Maastricht treaty by a vote of $50.7 \%$ to $49.3 \%$ in June 1992. See Craig R. Whitney, With Denmark, European Ministers Play for Time, N.X. Times, June 5, 1992, at A9.

152. French approval of the Treaty in September 1992 was achieved with a slim $51 \%$ majority. See Alan Riding, French Approve Unity Treaty, but Slim Margin Leaves Doubts, N.Y. Times, Sept. 21, 1992, at A1. 
and judicial challenges in the UK ${ }^{153}$ and Germany. ${ }^{154}$ The Council thus conspicuously sought to exploit subsidiarity's confidence-building function.

In order to achieve this purpose, however, the Edinburgh Summit had to demonstrate that the concept of subsidiarity has meaning and that its meaning is intelligible. The European Council thus defined subsidiarity as permitting the Community to act only if its objectives "cannot be sufficiently achieved by Member State action" and "can . . . be better achieved by action on the part of the Community." 155 According to the European Council-and this is strictly a matter of definition-subsidiarity does not ask questions about "the intensity or nature of the Community's action." 156 Such questions are addressed instead by the principle of proportionality, long since established by the Court of Justice ${ }^{157}$ and recently affirmed by the Maastricht Treaty. 158 As presented by the European Council, the principle of proportionality bars the Community from selecting a measure that imposes burdens disproportionate to the objective sought to be served. ${ }^{159}$ I shall argue in section $\mathrm{C}$ below that, although the European Council's distinction between subsidiarity and proportionality is analytically useful in defining the relevant questions for the political

153. See The Road Ahead for Maastricht, The Economist, July 31, 1993, at 42; see also The Maastricht Mire, The Economist, Mar. 13, 1993, at 20; Vote on Maastricht, The Economist, Oct. 31, 1992, at 16.

154. A German poll in late September 1992 reported that "only one voter in three would support the Maastricht treaty, and almost three-quarters object to giving up the rock-hard deutschmark in favor of a new and untested Euro-currency." Andrew Phillips, Europe in Crisis, Maclean's, Oct. 5, 1992, at 34. Constitutional challenges brought against the Maastricht Treaty were rejected by the German Constitutional Court on October 12, 1993. See German Constitutional Court Maastricht Decision, supra note 20; see also Last Harrumph for Maastricht, The Economist, Oct. 16, 1993, at 52.

155. Edinburgh Conclusions, supra note 11, at 6 .

156. Id. at 1.

157. See, e.g., Case 11/70, Internationale Handelsgesellschaft $\mathrm{mbH}$ v. Einführ-und Vorratstelle für Getreide under Futtermittel, 1970 E.C.R. 1125, 1130, 1972 C.M.L.R. 255.

158. Article 3b, which the Maastricht Treaty adds to the EC Treaty, recognizes in its final paragraph the principle of proportionality: "Any action by the Community shall not go beyond what is necessary to achieve the objectives of this Treaty." EC Treaty art. 3b (as amended 1992).

The Maastricht Treaty and the European Council alike thus treat subsidiarity and proportionality as separate though related concepts. More recently, the Commission suggested that subsidiarity is the broader concept, consisting of two branches, one being the showing of a "need-for-action" and the other being the requirement of proportionality proper. See infra note 200.

159. "Any burdens, whether financial or administrative, falling upon the Community, national governments, local authorities, economic operators and citizens, should be minimized and should be proportionate to the objective to be achieved." Edinburgh Conclusions, supra note 20, at 8.

The term proportionality also figures in United States constitutional and administrative law. The principle, according to Sunstein, requires that "[s] tatutes should be construed so that the aggregate social benefits are proportionate to the aggregate social costs." Sunstein, supra note 22 , at 181. 
branches and in channeling the Court of Justice's interventions, it is also inherently and deeply problematic. ${ }^{160}$

Turning to the subsidiarity principle proper, the European Council set out in its Edinburgh Conclusions a number of so-called subsidiarity "guidelines," 161 each of which, for different reasons, is disappointing in its usefulness to the institutions. The first guideline counsels the institutions to consider whether the problem addressed by a proposed Community measure "has transnational aspects which cannot be satisfactorily regulated by action by Member States."162 Unfortunately, problems that are truly transnational in character, and readily identifiable as such, are not the ones over which the institutions are likely to entertain serious subsidiarity doubts. With respect to such problems, the institutions might well wonder to what extent and in what form to intervene, but these questions, as the European Council itself insists, go to the issue of proportionality, not subsidiarity. ${ }^{163}$

The second guideline calls attention to whether a failure by the Community to act "would conflict with the requirements of the Treaty (such as the need to correct distortion of competition, or avoid disguised restrictions on trade, or strengthen economic and social cohesion) or would otherwise significantly damage Member States' interests."164 In a sense this guideline also addresses the easy cases, since the Commission and Council presumably will act whenever they deem it necessary to correct distortions of competition or avoid restrictions on trade, or to accomplish some other compelling Community objective. In other words, this guideline indicates where subsidiarity should stop, but not where it should start.

Unlike the European Council's first two guidelines, its third one addresses the hard cases. Unfortunately, however, it does so in an entirely conclusory fashion. This guideline requires the Council of Ministers, before acting, to find that the Community measure that is contemplated "would produce clear benefits by reason of its scale or effects compared with action at the level of the Member States." 165 This simply restates the principle of subsidiarity, ${ }^{166}$ though it perhaps has the merit of specifying that the comparative advantage of Community over Member State action must be "clear"; in other words, the proposed measure must be markedly superior to the Member State alternative, and not merely as good or slightly better. The Council also states that subsidiarity "must be substan-

160. See infra notes $\mathbf{2 2 7 - 2 3 6}$ and accompanying text.

161. See Edinburgh Conclusions, supra note 11, at 8 .

162. Id. at 7.

163. See id. at 2.

164. Id. at 7 .

165. Id.

166. The European Council also reiterated the principle of subsidiarity by urging that the Community "only take action involving harmonization of national legislation, norms or standards where this is necessary to achieve the objectives of the Treaty." Id. at 7. 
tiated by qualitative or, wherever possible, quantitative indicators,"167 which expresses a slightly different theme, namely that the subsidiarity principle imposes something in the nature of a burden of proof. The Council says nothing more about how such a burden might be met, except to dispel the idea that "presenting a single position of the Member States [on a given matter] vis-à-vis third countries" by itself justifies "internal" Community action on the matter. ${ }^{168}$

In my view, none of these admonitions meaningfully advances the political decision whether a proposed measure meets the test of subsidiarity. In section $C$ below, ${ }^{169}$ I suggest that determining whether the Community's objectives can or cannot be sufficiently achieved by Member State action requires a substantially more searching inquiry than those implied by the Edinburgh guidelines' shortcut formulations. Although the Edinburgh exercise underscored in reassuringly simple "summit" language the European Council's attachment to the subsidiarity principle, it left the operational aspects of the principle largely unexplored.

\section{B. Subsidiarity in the Community Tradition}

Equally problematic, particularly from a confidence-building point of view, was the European Council's attempt to depict subsidiarity both as comfortably within the Community tradition and at the same time reflective of a new sensitivity to localism. In aid of the first proposition, the European Council asserted that "the principle of attribution of powers" has always dictated that "national powers are the rule and the Community's the exception." 170 As might be expected-and as this Article's earlier discussion of enumeration, preemption, and implied powers shows ${ }^{171}$-matters are not quite so simple. In this section, I take up the question of subsidiarity's novelty in the Community context.

The claim that the Community practiced subsidiarity well before the Maastricht Treaty proclaimed it to be a general Community law principle is not entirely without substance. From the outset, the EC Treaty suggested that Member State laws should be harmonized only "to the extent required for the proper functioning of the common market."172 The legal form that the Treaty drafters initially envisioned as the main harmonization instrument was the directive, which itself reflectis subsidiarity

167. Id.

168. Id.

169. See infra notes 206-236 and accompanying text.

170. Edinburgh Conclusions, supra note 11, at 2. On the Commission's claim that subsidiarity has always been part of the Community treaty structure, see Gretschmann, supra note 27, at 45, 53-57; Daniel G. Partan, Subsidiarity in EC Environmental Regulation, paper delivered at Symposium on Subsidiarity and Harmonization: Defining European Federalism, supra note 4 (on file with the Columbia Law Review).

171. See supra notes $87-118$ and accompanying text.

172. EG Treaty art. $3(\mathrm{~h})$. 
thinking. ${ }^{173}$ The use of directives, as compared to regulations, presupposes that the Member States can safely be relied upon to select the appropriate "form and methods" for implementing Community policy. ${ }^{174}$ In the final analysis, of course, it is impossible to tell from the form of a Community measure whether its content is respectful of subsidiarity. The Council may easily enact legislation that, while taking the form of a directive, dictates policy on matters that the States acting alone could have done a perfectly good job of regulating, in breach of the subsidiarity principle. Conversely, the Council may adopt a regulation (i.e., a directly applicable instrument) and still take all due account of the States' willingness and capacity to act on the matter at hand.

More indicative of subsidiarity than the institutions' choice of legislative form is their choice of legislative approach. In fact, the Commission and Council commonly use legislative instruments that are specifically designed to avoid unnecessary Community interventions. One such instrument is the mutual recognition of national standards. If the Community can afford to achieve its objectives by ensuring that the regulatory regime of each Member State meets certain minimum Community criteria, then it can leave the Member State regimes in place, and simply require each to give full faith and credit to the certifications made by the others. The Community thereby advances the free movement principle, without displacing Member State law or exacting an unnecessary degree of uniformity. While the Council may of course fail on any given occasion to show adequate self-restraint in defining the minimum criteria, the technique of mutual recognition acknowledges in principle the States' capacity to regulate their economies separately, and still not jeopardize the Community's essential regulatory goals. ${ }^{175}$

A second legislative technique-or set of techniques-redolent of subsidiarity is the Council of Ministers' "new approach to technical harmonization," first announced in those terms in 1985. ${ }^{176}$ The Council sought through this approach to streamline the harmonization process, chiefly by limiting the quantity and detail of issues that any given directive needed to address. The mutual recognition of standards mentioned

173. Article 189 of the EC Treaty reads: "A directive shall be binding, as to the result to be achieved, upon each Member State to which it is addressed, but shall leave to the national authorities the choice of form and methods." "Regulations" by contrast are defined in Article 189 as "binding in [their] entirety and directly applicable in all Member States." EC Treaty art. 189.

174. Id. However, EC Treaty Article 100a, added by the 1986 Single European Act, deliberately invited harmonization through means other than directives, notably through directly applicable regulations. It authorized the use of "measures," not merely "directives," as under the original harmonization provision, Article 100. See EC Treaty art. 100 (as in effect in 1985).

175. For an example of Community legislation employing the technique of mutual recognition of national standards, see Council Directive 75/363 In Respect of Activities of Doctors, 1975 O.J. (L 167) 14.

176. Council Resolution of May 7, 1985 on a New Approach to Technical Harmonization and Standards, 1985 O.J. (C 136) 1. 
above plainly serves the same goal. But the "new approach" counselled in more general terms against the adoption of detailed and comprehensive directives, urging the Community instead to limit harmonization to those aspects of a regulatory problem deemed to be "essential," and to leave aside all others. Whether the issues left over are eventually regulated separately by the Member States or by private or government-supported standards bodies, or left unregulated altogether, is presumably not a matter of Community concern, provided the "essentials" contained in the directive are respected and significant barriers to intra-Community trade are not reintroduced. ${ }^{177}$ The Council's chief purpose in adopting a more streamlined approach to harmonization may have been to lighten its legislative burden, particularly with the 1992 single market program on the horizon; but this preference necessarily also conveyed a sense of confidence in the States' ability to address matters within their legislative sphere without causing undue detriment to Community policy.

Similarly suggestive of subsidiarity is the Council of Ministers' practice of using legislative language that expressly allows the Member States to adopt a still higher level of protection should they so choose. ${ }^{178}$ This is not to say that the use of non-preemption language guarantees subsidiarity; even a non-preemptive Community measure may not have been necessary for achieving the objective sought, or if necessary, might have been made less far-reaching. Nevertheless, the practice of expressly allowing more protective Member State legislation shows a healthy appreciation for the States' capacity to govern a matter that the Community could constitutionally regulate, and it should remove any doubt about their entitlement in principle to do so. ${ }^{179}$

Under the definitions adopted by the European Council at Edinburgh, ${ }^{180}$ these three instruments-the preference for directives, ${ }^{181}$ the

177. The idea is that once the Commission certifies a national standard as meeting a directive's minimum standards, all other Member States would be required to treat goods manufactured under those standards as in conformity with the directive. See, for example, Council Directive 88/378 on the Safety of Toys, 1988 O.J. (L 187) 1.

178. For an example of such permissive language, see Article 5 of Council Directive $75 / 129$ on the Approximation of the Laws of the Member States Relating to Collective Redundancies, 1975 O.J. (L 48) 29 ("This Directive shall not affect the right of Member States to apply or to introduce laws, regulations or administrative provisions which are more favorable to workers."). For further examples, see Articles 9, 10, 13, and 15 of Council Directive 85/374 Concerning Liability for Defective Products, 1985 O.J. (L 210) 29.

179. Non-preemption does not, of course, leave Member States entirely free in their protective efforts. Even if not preempted as such, Member State legislation may not contravene any Community law principles, such as free movement or non-discrimination based on nationality.

180. See supra notes $156-159$ and accompanying text.

181. At the Edinburgh Summit, the Council urged that:

The Community should legislate only to the extent necessary. Other things being equal, directives should be preferred to regulations and framework directives to detailed measures. Non-binding measures such as recommendations should be 
"new approach to harmonization"182 and express legislative non-preemption ${ }^{183}$-more closely serve the purposes of proportionality than subsidiarity. Nevertheless, each of them received the Council's specific endorsement at Edinburgh. The Council also urged the Community institutions, in the interest of proportionality, to favor interventions that facilitate and coordinate Member State actions rather than compel them, whenever the institutions could still thereby achieve their purposes. ${ }^{184}$ Since the distinction between whether the Community should act in place of the States and how far it should go in doing so is artificial at best, the Council's injunctions about proportionality can scarcely help but serve subsidiarity's purposes as well.

The foregoing discussion shows that while the rhetoric of subsidiarity is unprecedented in the Community, the practice of subsidiarity is not. It is nevertheless difficult to tell just how deliberately and systematically the institutions have practiced subsidiarity in their conduct of policy analysis or in their design of legislation. Rightly or wrongly, it remains a widelyheld impression that the Community commonly legislates on matters bearing a tenuous or strained connection with the internal market, that it often acts not because acting has been shown to be necessary but simply because it might be useful, and that even when it legislates on a proper subject, it often does so in unnecessary detail and in search of unnecessa-

preferred where appropriate. Consideration should also be given where appropriate to the use of voluntary codes of conduct.

Edinburgh Conclusions, supra note 11, at 9.

182. Reinforcing the "new approach to harmonization," the Council insisted that:

Community measures should leave as much scope for national decision as possible, consistent with securing the aim of the measure and observing the requirements of the Treaty. While respecting Community law, care should be taken to respect well established national arrangements and the organization and working of Member States' legal systems. Where appropriate and subject to the need for proper enforcement, Community measures should provide Member States with alternative ways to achieve the objectives of the measures.

Id. at 8 .

183. With regard to express legislative non-preemption, the Council announced that: Where it is necessary to set standards at Community level, consideration should be given to setting minimum standards, with freedom for Member States to set higher national standards, not only in the areas where the treaty so requires (118a, 130t) but also in other areas where this would not conflict with the objectives of the proposed measure or with the Treaty.

Id.

184. "Where appropriate under the Treaty, and provided this is sufficient to achieve its objectives, preference in choosing the type of Community action should be given to encouraging cooperation between Member States, [to] coordinating national action or to complementing, supplementing or supporting such action." Id. at 9.

The Council also urged, by way of proportionality, that Community legislation target particular States and omit others, where appropriate: "Where difficulties are localised and only certain Member States are affected, any necessary Community action should not be extended to other Member States unless this is necessary to achieve an objective of the Treaty." Id. 
rily standardized results. ${ }^{185}$ Even if this impression is no longer accurate (if it ever was), it is nevertheless a fact of which the architects of European integration need to be aware.

One way for the Community to acknowledge that it may not always have practiced subsidiarity as seriously as it might have would be to reconsider existing legislation from a subsidiarity point of view. Interestingly, although the subsidiarity provision of the Maastricht Treaty requires only prospective application of the principle, ${ }^{186}$ the consensus in political and academic quarters alike is that the institutions should also reexamine legislation already on the books, ${ }^{187}$ as they have in fact begun to do. ${ }^{188}$ It is unlikely that at the time they enacted such legislation, the institutions asked the precise questions that subsidiarity now seems to require. It is also possible that existing legislation was adopted in accordance with the principle of subsidiarity, but that circumstances have since changed in ways which suggest that the legislation be repealed or amended, ${ }^{189}$ or that the institutions simply erred in their judgment that they needed to act in place of the States. Another way in which the Community might hasten the process of eliminating unnecessary legislation is by providing for its automatic expiration after a certain period, unless specifically renewed. ${ }^{190}$ Such so-called "sunset" provisions are not, however, in the tradition of European legislative practice.

185. See David Buchan, Biotech Groups Find Bright New World Slow to DawnEurope's Patent Legislation and Regulations Have Caused Frustration in the Sector, Fin. Times, Apr. 27, 1992, at 2; see also Charles Batchelor, Owners Driven Up the Wall, Fin. Times, Dec. 15, 1992, at 10; Roland Gribben, CBI Calls for Speed in Paper Mountain War red tape Government Urged to Act on De-Regulation, The Daily Telegraph (London), June 7, 1993, at 29.

186. Article $3 \mathrm{~b}$ of the EC Treaty allows the Community to act "only if and in so far as the objectives of the proposed action cannot be sufficiently achieved by the Member States." EC Treaty art. 3b (emphasis added).

187. See generally Alistair Alcock, Subsidiarity and Adverse Possession, 142 New L.J. 1386 (1992). Following the 1992 European Council meeting at Edinburgh, France and the United Kingdom drew up a list of specific Community legislation in force-mostly on environmental protection, consumer protection and social affairs-that they believed needed to be repealed or amended in light of the subsidiarity principle. These included, for example, directives on the safety of drinking and bathing water, driving speed limits, blood alcohol tests for drunken driving, pharmaceutical pricing, indirect taxation of securities, and the protection of wild birds. See Brian Love, Britain and France Team Up to Seek Repeal of EC Laws, Reuters News Service-Western Europe, June 29, 1993, available in LEXIS, Reuters Textline.

On the Commission's November 1993 report to the European Council proposing the repeal of certain legislation in the interest of subsidiarity, see infra notes 199-205.

188. See infra notes 192-198 and accompanying text.

189. The Edinburgh European Council concluded that subsidiarity "allows Community action to be expanded where circumstances so require, and conversely, to be restricted or discontinued where it is no longer justified." Edinburgh Conclusions, supra note 11 , at 4 .

190. See Joseph F. Zimmerman, Federal Preemption: The Silent Revolution 160 (1991) ("The solution [to the problem of shifting the burden of reviewing and adjusting statutes] is the incorporation of a 'sunset' provision in each preemptive statute."). An 
The Commission's willingness to reexamine existing legislation under a subsidiarity principle not recognized or enforced when the legislation was passed has obvious political advantages. It demonstrates with some clarity that subsidiarity has meaning and will make a difference. If subsidiarity is the promise on the basis of which the States and their various subcommunities are supposed to accept the accretions in Community power under Maastricht, and to continue on the path toward European political union, this is an important showing indeed. But the principle of subsidiarity may demand retroactive application for consistency's sake too. The Community may find it awkward to enforce existing legislation when analogous proposals for future legislation are being amended, withdrawn or defeated (or new legislation possibly even invalidated) on subsidiarity grounds. ${ }^{191}$

During ratification of the Maastricht Treaty, the Commission reexamined the legislative proposals then pending before the Council and Parliament, and began the much more daunting task of reviewing existing legislation for its continuing conformity with subsidiarity. ${ }^{192}$ The Commission quite properly also reconsidered legislative initiatives that were still in the planning stage. ${ }^{193}$ Indications are that the reassessment produced results. By the time of the Edinburgh Summit, the Commission had decided to withdraw three proposed directives ${ }^{194}$ and to revise six more; ${ }^{195}$ it also announced its intention to consider withdrawing or revising a number of others. ${ }^{196}$ Finally, certain initiatives still in the plan-

advantage of such a mechanism is that it addresses the problem of legislative "entrenchment." Particularly in a system of super-majority voting, it may be difficult to amass the political support needed to pass new legislation that "positively" repeals existing legislation. Automatic expiry of legislation would place the burden of collecting supermajority support on those who would have legislation continue in force beyond its term.

191. Alcock claims that the Commission will find it difficult to maintain enforcement actions against Member States under Article 169 of the EC Treaty for their failure to implement Community rules that, under the principle of subsidiarity, should never have been adopted. See Alcock, supra note 187, at 1386.

192. See Edinburgh Conclusions, supra note 11, at 1 .

193. See id. One legislative project that France and the United Kingdom have jointly urged the Commission to abandon on subsidiarity grounds is a directive establishing Community-wide hygiene standards for zoos. See Love, supra note 187.

194. The proposals withdrawn concerned: 1) compulsory labeling of the nutritional value of foodstuffs, 2) radio frequencies for land-based telecommunications with aircraft, and 3) radio frequencies for remote-processing in road transport. See Edinburgh Conclusions, supra note 11 , at 2.

195. Revisions will be made to proposals on 1) public takeover bids, 2) a common definition of a Community shipowner, 3) comparative advertising, 4) shoe labeling, 5) liability of suppliers of services, and 6) protection of persons regarding data processed digitally. In each case, the Commission plans to further reduce the proposal to general principles and to allow the Member States to provide greater detail. See id. at 8.

196. These proposals dealt with a wide range of matters, including animal conditions in zoos, indirect taxation of securities transactions and capital accumulation, value added taxation of ships' supplies, the temporary importation of motor vehicles, and classification of documents of Community institutions. See id. 
ning stage were abandoned, ostensibly on subsidiarity grounds. ${ }^{197}$ The Commission subsequently withdrew a still much larger number of pending legislative proposals. ${ }^{198}$ The Commission, with the European Council's obvious blessing, evidently proceeded in the sensible belief that, particularly in matters of politics, actions speak louder than words.

In November 1993, at the request of the European Council at Edinburgh, the Commission produced a report on the Adaptation of Community Legislation to the Subsidiarity Principle (Adaptation Report). ${ }^{199}$ The report identified the existing Community legislation in all areas that the Commission had determined to revise, either in the interest of subsidiarity or proportionality. ${ }^{200}$ Revision would take one of three forms: recasting, simplification, or repeal. Recasting means reordering in a more consistent and coherent fashion; simplification refers to the elimination of unnecessary detail; and repeal consists of eliminating legislation

197. Among initiatives dropped were those relating: to 1) harmonization of vehicle number plates, 2) the regulation of gambling, and 3) harmonization of technical standards for diet foods, second-hand machinery, and theme park equipment. See id.

198. See Commission Withdraws "Superfluous" Proposals, Reuters News ServiceWestern Europe, July 29, 1993, available in LEXIS, Reuters Textline. At the European Council's June 1993 summit in Copenhagen (its first summit meeting following the Edinburgh Summit of December 1992), the heads of state and government "noted with satisfaction that the Commission is now submitting proposals only when it considers that they fulfil the subsidiarity criteria, and welcomed in general the substantial reduction in the volume of Community legislation foreseen in the Commission's legislative programme for 1993 compared to earlier years." European Council in Copenhagen, Conclusions of the Presidency, June 21-22, 1993, available in LEXIS, Reuters Textline, European Commission Press Releases, June 22, 1993 I 15. At Copenhagen, the European Council concluded that the Commission and the Council alike "are now applying the principles, guidelines, and procedures on subsidiarity decided at Edinburgh as an integral part of the decision making procedure" and urged the European Parliament to do likewise. Id.

199. Commission of the European Communities, Report to the European Council on the Adaptation of Community Legislation to the Subsidiarity Principle, COM(93)545 final (Nov. 24, 1993) [hereinafter Adaptation Report]. The European Council commented favorably on the report and urged early Commission action pursuant to it. European Council in Brussels, Conclusions of the Presidency, Dec. 10-11, 1993, at 22-23.

The Council, Commission, and Parliament had previously agreed that the Commission should prepare an annual report for the Parliament and the Council on compliance with the principle of subsidiarity, and that the report should occasion a public debate in the Parliament, with the participation of the other two institutions. See Interinstitutional Agremeent on Procedures for Implementing the Principle of Subsidiarity, Doc. 9510/93 (Luxembourg, Oct. 25, 1993) (Annex) [hereinafter Interinstitutional Agreement]. See infra notes 206, 213, 217.

200. In fact, the Report restates somewhat the relationship between the subsidiarity and proportionality principles set out by the European Council at Edinburgh. See supra notes 155-169 and accompanying text. According to the Commission, subsidiarity is the larger concept, having two distinct branches. One branch-the one by now more closely identified with subsidiarity-is "the need-for-action" test; the other is "proportionality." Adaptation Report, supra note 199 , at 5 . Under this analysis, proportionality is merely a species of subsidiarity. 
that is no longer needed. ${ }^{201}$ While promising that the process would not degenerate into a "free-for-all, in which . . . various parties . . . propose the revision or repeal of legislation for reasons of expediency,"202 the Commission cited hundreds of enactments that it would seek to recast, ${ }^{203}$ simplify, ${ }^{204}$ or repeal ${ }^{205}$ in the near term. The sheer number of changes projected in the Adaptation Report is of course very impressive. However, the report's clear emphasis on recasting and simplification suggests that the operation may end up streamlining many specific Community enactments, and thus pruning the corpus of EC legislation, but still failing to return very many matters to governance by the Member States. In this respect, the Adaptation Report only points up the importance of asking and answering the right questions in subsidiarity's name. It is to this aspect of the problem that I now turn.

\section{Subsidiarity as a Mode of Legislative Analysis}

Having examined how the Community has defined the principle of subsidiarity and thus far sought to implement it, I now look more closely at what it will mean in the future to treat subsidiarity essentially as a legislative precept. This entails, first, clarifying the nature of the legislative inquiry and its institutional implications. I trace these aspects of subsidiarity in the first part of this section. However, understanding the legislative practice of subsidiarity also entails acknowledging the complex analytic and policy questions that application of the principle will inevitably raise. In the second and third parts of this section, I attempt to show that taking subsidiarity seriously as a legislative norm requires confronting both the difficult distinction between policy measures and harmonization measures and the necessity of making conscious tradeoffs between subsidiarity and other legislative principles, notably proportion-

201. See Adaptation Report, supra note 199, at 6 . The goal of simplification is to be advanced through wider use of certain legislative techniques-notably the new approach to harmonization and the mutual recognition of certificates-described above. See id. at 13-14; supra notes 174-177 and accompanying text.

202. Adaptation Report, supra note 199, at 7 .

203. Notably, the Community customs code is slated to be recast, as are directives and regulations on rights of residence of Community nationals, pharmaceutical products, competition policy, and trade mechanisms for agricultural products (e.g., production licenses, refunds, levies, guarantees). Id. at 10-12.

204. The Commission is exploring simplification in many important fields: technical standards (particularly in relation to foodstuffs and machinery), professional qualifications, the environment, animal welfare, and social policy (i.e., workers' rights). Areas in which the Commission is also exploring possibilities for simplification are indirect taxation, company law, agricultural markets, transport, fisheries, energy, and consumer protection. See id. at 12-22.

205. According to the Commission, the recasting and simplification of legislation will inevitably entail the repeal in whole or in part of existing legislation. See id. at 23. However, the Commission has identified areas in which legislation might be repealed outright because it no longer appears justifiable in terms of subsidiarity. See id. at 23-24. 
ality, that are also deemed to be fundamental in the Community legal order.

1. Institutional Aspects of Subsidiarity. - The burden of respecting subsidiarity in the exercise of Community power would seem to lie initially with the Commission, which enjoys a virtual monopoly over conceiving and drafting legislative proposals. The European Council at Edinburgh suggested that the Commission should consult with the Member States at an early stage on "the subsidiarity aspects of a proposal," and include in the explanatory memorandum accompanying any proposal made to the Council of Ministers a statement "justif[ying the] initiative with regard to the principle of subsidiarity."206 One can readily imagine a reasoned Commission forecast of (1) the actions, if any, that the Member States could plausibly be expected to take to accomplish the purposes underlying the proposed Community measure, (2) the respective likelihood of those actions occurring, (3) the probable consequences of the actions, and (4) a comparison of their probable effectiveness with that of the Community measure under consideration. Presumably, consideration would also be given to leaving the matter unregulated at all levels of government.

A "subsidiarity impact analysis," to coin a not altogether original description of such reasoning, might cause the Commission to conclude either that no alternative measures the Member States could reasonably be expected to take would adequately serve the Community's purposes and that the Commission proposal should go forward, or that adequate Member State alternatives in fact exist and that the Commission proposal should not proceed. ${ }^{207}$ The analysis might of course produce much less conclusive results. In any event, the Commission's impact analysis could

206. Edinburgh Conclusions, supra note 11, at 10. Since the Edinburgh Summit, Commision proposals for legislation have been required to be accompanied by an explanation of why measures at the EC level are necessary. See Upsizing: The Difficulty of Growing Bigger Gracefully, The Economist, July 3, 1993, at 18-19.

The Community institutions formally agreed at Luxembourg in October 1993 that "[i]n exercising its right of initiative, the Commission shall take into account the principle of subsidiarity and show that it has been observed" and that "the explanatory memorandum for any Commission proposal shall include a justification of the proposal under the principle of subsidiarity." Interinstitutional Agreement, supra note 199.

207. President Delors has instructed civil servants of the Community not to propose measures that would be incompatible with the principle of subsidiarity. See Dictionary Time, The Economist, Dec. 9, 1989, at 52.

Following the Edinburgh Summit, the Assembly of Regions of Europe drew up a detailed "questionnaire" on subsidiarity for any body proposing Community action to complete and to attach to any such proposal, accompanied by an explanatory memorandum. The questionnaire covers the following issues:

1. The basis of competence in the Treaty on European Union: (a) The planned measure is based on which article? (b) Does the article contain conditions limiting recourse to Community competence?

2. The objectives sought by the Treaty: (a) What concrete objectives are sought by the planned action? (b) What reasons justify the need to take action?

(c) Is the action related to any previous Community action? 
constitute the record on which the other institutions (notably the European Parliament, the Economic and Social Committee and the Council of Ministers) base their own initial assessments of any Commission proposal. On the other hand, the Commission's analysis obviously should not in any way limit those institutions' right to make their own factual inquiries, perform their own political and economic analyses, and reach their own ultimate conclusions.

The Commission took its November 1993 Adaptation Report ${ }^{208}$ as a further occasion to describe the type of analysis that subsidiarity entails. While depicting subsidiarity more as "a state of mind" than "a set of procedural rules," 209 the Commission nevertheless affirmed that subsidiarity required it to answer in the form of an explanatory memorandum a prescribed set of questions before proposing a new measure within the Community's and Member States' shared competence. Among the issues to be addressed in any such "justification" are:

(a) What are the aims of the proposed action in terms of the Community's obligations? ...

3. The need for the Community action in question: (a) Which Member States are concerned by the problem? Does the problem appear the same way everywhere? (b) Which Member States have dealt with this problem to date? How did the states in question solve the problem? (c) Are there alternative solutions at lower echelons at Community level? If yes, what are they? (d) Why can't the objectives in question be attained at Member State level? (e) What would be the disadvantages and costs if the Community failed to intervene? ( $f$ ) What arguments can be used to prove that EC goals would be more easily attained by the measure in question than by measures at Member State level?

4. Implementing Community action: (a) Would coordination between Member States or Community support for national measures be enough to attain the objectives? If no, why not? (b) Has the Community already made a recommendation that has not been followed by the Member States? (c) Is mutual recognition of different regulations possible? If no, why not? (d) Is complete harmonisation necessary or is it enough to enact minimum provisions? (e) Would it be sufficient to adopt a regulatory framework? If no, why not? (f) Is a uniform and directly applicable regulation (order) necessary or would the adoption of a directive be sufficient? (g) Would a regulation of limited duration suffice?

5. Extending Community actions: (a) Is the adoption of implementing regulations necessary? If necessary, at what level will they be adopted? (b) If implementation of Community action is limited to Community level, on an exceptional basis, why is implementation at Member State or regional level insufficient? (c) If verification of implementation is incumbent upon the Community, why can this responsibility not be carried out by the Member States? (d) Who controls the attainment of the objectives of Community actions and on what criteria?

EC: Subsidiarity-Possible Reassignment of Powers to States and Regions, available in LEXIS, Reuters Textline, Agence Europe, Mar. 3, 1993.

208. See Adaptation Report, supra note 199.

209. Id. at 2. 
(c) What is the Community dimension of the problem (in other words, how many Member States are involved and what solution has been applied to date)?

(d) What is the most effective solution, given the means available to the Community and to Member States?

(e) What is the specific added value of the proposed Community action and the cost of failing to act? 210

The Commission also undertook to publish its explanatory memoranda in the Official Journal together with the proposals to which they relate, thus enabling interested parties to comment on the subsidiarity aspects of the proposals before their adoption. ${ }^{211}$ According to the Commission, these procedures-which it had already begun to follow-had caused it to put forward fewer legislative proposals in 1993 than in prior years. ${ }^{212}$

Although the Commission is the right body to make the initial investigative and analytic investment into the subsidiarity aspects of legislation, the European Council at Edinburgh nevertheless placed greater emphasis on the Council of Ministers' role in guaranteeing subsidiarity, presumably because of its greater decisional authority as an institution.

The examination of the compliance of a measure, with the provisions of Article $3 \mathrm{~b}$ [i.e. subsidiarity] ... should become an integral part of the overall examination of any Commission proposal and be based on the substance of the proposal .... This examination includes the Council's own evaluation of whether the Commission proposal is totally or partially in conformity with the provisions of Article $3 \mathrm{~b}$ (taking as a starting point for the examination the Commission's recital and explanatory memorandum) and whether any change in the proposal envisaged by the Council is in conformity with those provisions. The Council decision on the subsidiarity aspects shall be taken at the same time as the decision on substance and according to the voting requirements set out in the Treaty. ${ }^{213}$

\section{Id. at 3.}

211. See id. at 3-4.

212. See id. at 4. The Commission specifically undertook in its November 1993 Adaptation Report to notify the Council and Parliament, and through the Official Journal all interested parties, of its reasons for not pursuing proposals initially included in its legislative program for a given year. See id.

213. Edinburgh Conclusions, supra note 11 , at 11 . The last quoted sentence is meant to ensure that the Council considers subsidiarity as an integral part of its legislative inquiry and legislative judgment. The European Council underscored the point by urging the Council of Ministers not to create "a system of preliminary or parallel decision-making" on the subsidiarity issue. Id.

The Interinstitutional Agreement signed at Luxembourg in October 1993 requires the Council, in exercising its legislative powers under the EC Treaty, to demonstrate its observance of the principle of subsidiarity. More specifically, it requires the Council to justify in terms of subsidiarity any amendment that it makes to a Commission proposal if the amendment "entails more extensive or intensive intervention by the Community." See Interinstitutional Agreement, supra note 199.

The October 1993 ruling of the German Constitutional Court upholding the constitutionality of Germany's ratification of the Maastricht Treaty placed considerable 
Since the Council is itself composed of Member State representatives, the Member State governments are themselves primarily responsible for making subsidiarity work. ${ }^{214}$ However, the Edinburgh Conclusions also specifically urged the Council's various working groups and its Committee of Permanent Representatives to include subsidiarity considerations in their own reports on any Commission proposal, and asked that the Council report to the European Parliament (in those cases in which the Parliament has a distinct legislative voice) on whether the Commission proposal does or does not comport with the principle of subsidiarity, and why. ${ }^{215}$ Although the European Council said nothing at Edinburgh about how subsidiarity should specifically figure into Parliament's legislative opinions under the parliamentary consultation, cooperation, and codecision procedures, ${ }^{216}$ it seems evident that Parliament also should evaluate the proposals before it from a subsidiarity point of view, and do so with full freedom of inquiry and judgment.217

Subsidiarity thus essentially describes a method of policy analysis that each participant in the Community's legislative process should follow in deciding whether to propose, endorse, or enact a given measure. ${ }^{218}$ The

emphasis on subsidiarity as a check on the Community's exercise of powers. It also underscored the Council's special obligation in this regard:

If the Community legislator wants to exercise a legislative competence attributed to it, it must first satisfy itself-and clearly establish in conformity with Article 190 of the EEC Treaty [requiring a statement of reasons] - that the objectives of the action envisaged cannot be adequately accomplished at the national level through action of the Member States.

German Constitutional Court Maastricht Decision, supra note 20, at 82 . According to the Court, "the extent to which the principle of subsidiarity will prevent the erosion of the competence of the Member States ... depends ... above all on the practice of the Council, which is the Community's veritable legislature." Id. at 83.

214. For an admonition by the German Constitutional Court to the German government to use its influence in the Council in favor of subsidiarity, and to the German Parliament to pressure the government to do so, see German Constitutional Court Maastricht Decision, supra note 20, at 83.

215. See Edinburgh Conclusions, supra note 11, at 12.

216. See supra note 134 and accompanying text.

217. In November 1992, the major parties in the European Parliament adopted a joint resolution to the effect that a measure's respect for subsidiarity should be determined through consultation among the political organs of the Community and not through judicial review in the Court of Justice. See Parliament Wants a Say in Checking Up on Subsidiarity, European Report No. 1814 (Nov. 21, 1992). See generally Panayotis Roumeliotis, The Subsidiarity Principle: The View of the European Parliament, in Subsidiarity: The Challenge of Change, supra note 6 , at 31 .

In the Interinstitutional Agreement signed at Luxembourg in October 1993, see supra note 199, the institutions required Parliament to demonstrate its observance of the principle of subsidiarity and, more particularly, to justify in terms of that principle any amendment to a Commission proposal that would produce more significant intervention by the Community. See Interinstitutional Agreement, supra note 199, at II(3), III(2).

218. Representatives of the Benelux countries described subsidiarity as "foremost a state of mind made up of moderation in the exercise of power and reciprocal trust in the elaboration and execution of Community decisions and legislation." Birmingham Summit: 
European Council's apparent emphasis at Edinburgh on the Council of Ministers is accordingly misleading. As the Community's legislative processes become more varied and complex, with different institutions playing different roles (proposing, voicing opinions on, suggesting amendments to, requiring or performing second readings of, and finally adopting measures), 219 each of the institutions will inevitably be drawn into incorporating the reasoning of subsidiarity into its decisional processes. The European Council's request at Edinburgh that the Commission review all proposed and existing legislation in preparation for the European Council's December 1993 Brussels Summit reflects partial recognition of this fact. ${ }^{220}$

2. Distinguishing Policy Measures and Harmonization Measures. - My discussion of subsidiarity as a set of procedural instructions to the institutions has thus far proceeded as if all Community legislation were basically alike. In formulating more precisely the legislative inquiry that subsidiarity entails, it is actually crucial to distinguish between legislation that aims at establishing substantive regulatory policy, on the one hand, and legislation that aims at promoting the establishment and functioning of the internal market, on the other. However awkward, this is a distinction that the structure of the EC Treaty imposes on us. Much Community legislation falls squarely within substantive policy areas-e.g., environmental protection, occupational safety, research and technological development, and the newer program areas provided for by the Maastricht Treaty 221 -for which the Treaty expressly confers legislative competence on the Community institutions. The operation of subsidiarity in the analysis of what we may thus conveniently characterize as "policy measures" is not particularly difficult to describe. Essentially, subsidiarity entails defining as precisely as possible the objectives meant to be accomplished, and comparing the Community measure proposed to the measures that could be taken independently by the Member States-or to no governmental intervention at all-in terms of its effectiveness in achieving those objectives.

Subsidiarity operates rather differently for what may be called "harmonization measures," by which I mean measures whose stated rationale is to reduce or eliminate non-tariff barriers to trade resulting from regulatory action that the Member States have otherwise properly taken on matters within their jurisdiction. In this case, the proverbial Community measure is not a piece of legislation that advances a particular policy for which the Community bears legislative responsibility under the Treaty, but rather a directive requiring the harmonization of Member State policies on matters for which the Member States remain at least nominally

Memorandum by the Benelux Countries, Europe, Agence Internationale d'Information pour la Presse, Oct. 12-13, 1992, at 5.

219. See supra note 134 and accompanying text.

220. See supra note 187 and accompanying text.

221. See supra notes $42-49$ and accompanying text. 
responsible. In order to respect subsidiarity in the adoption of harmonization measures, the Community presumably should intervene only where necessary for the internal market to work effectively, and even then only to the extent necessary. ${ }^{222}$ Pursuing subsidiarity in the design of harmonization measures can, however, be highly problematic, not only in practice but also in theory. Generally speaking, the regulatory environment can always be made more uniform. If one were to consult common market criteria alone, disregarding other values such as diversity among the goods and services available in the market, one would opt for maximum regulatory uniformity.

Accordingly, the only way to make room for subsidiarity in designing harmonization measures is consciously to curtail them so that they are not enacted unless they make significant and justifiable internal market gains, and so that they in any event go no further than reasonably necessary in order to achieve those gains. Such a harmonization strategy would in effect advance subsidiarity at the same time as it advances proportionality, as if conflating the two. In theory, the Community institutions would seek to reduce or eliminate disparities among Member State regulations only to the extent that those disparities substantially impede the free movement of one or more of the factors of production (thereby impairing the commonness of the market) and the gains in market integration outweigh the specific loss of Member State autonomy that results. Determinations of this sort are of course profoundly political in that they entail judgments about how much each incremental gain in economic integration is worth in costs to certain other values, notably the values (for example, diversity) underlying subsidiarity itself. ${ }^{223}$ One supposes that the Commission and Council were in the habit of asking themselves precisely these questions long before they talked about subsidiarity, which may help explain why subsidiarity already had a familiar ring to it when it was first proclaimed in the Maastricht Treaty to be a fundamental Community law principle. Still, if subsidiarity is to be taken seriously in the years ahead, and to be applied to harmonization measures as well as policy measures, these questions will have to be asked more explicitly and systematically than ever before.

It should now be clear why the practice of subsidiarity in the adoption of policy measures can by contrast be relatively straightforward. When the Community legislates directly on subjects falling within its sphere under the Treaties, subsidiarity requires it to ascertain that the Member States, left to their own devices, could not do an adequate job of

222. Questions about the extent of Community intervention may more properly be considered questions of proportionality than subsidiarity. See supra notes 156-159 and accompanying text. The "new approach to technical harmonization," discussed supra notes 176-177 and accompanying text, was thus at least as much an instrument of proportionality as subsidiarity. For a discussion of the interrelationship between subsidiarity and proportionality, see infra notes 227-236 and accompanying text.

223. See supra notes $20-29$ and accompanying text. 
furthering the Community's basic policy objectives. This too is obviously a political call, but in a quite different sense. As applied to these measures, subsidiarity does not require deciding how much each incremental gain in market integration is worth in terms of sacrifice to the political autonomy of the Member States and their various subcommunities. It does not pit two opposing values-integration and localism-against one another, but demands, in the acknowledged interest of one of themnamely localism-that Member State action be preferred if it would effectively accomplish the Community's purposes. The somewhat greater ease of applying subsidiarity to policy measures than to harmonization measures may help explain why subsidiarity figures so much more prominently in connection with the former (notably environmental and consumer protection, social policy, and economic and monetary union) than with the latter.

Notwithstanding my claim that subsidiarity is analytically more manageable when the Community makes policy directly than when it makes policy indirectly, the analysis can in either case be exceedingly complex. Let us take the seemingly simpler case of policy measures. Comparing the efficacy of a Community proposal, on the one hand, with action that might be taken separately or jointly by the Member States, on the other, sounds deceptively easy, familiar as we now are with the practice and theory of cost-benefit analysis. Assessments of comparative utility are difficult to conduct under ordinary circumstances, but they are substantially more difficult to conduct when one of the measures to be compared-in this case action at the Member State level-may itself be entirely hypothetical. In order to practice subsidiarity, the institutions need to forecast a whole range of actions or inactions in which the Member States might engage in relation to a given Community goal, if the Community institutions allowed them to, and make a utility assessment of each. Moreover, each Member State "option" has to be discounted for the possibility that not all of the Member States may take the action contemplated on a timely or adequate basis or indeed at all. ${ }^{224}$ It is only after some generalized assessment of Member State potential emerges from this enormously contingent and variable analysis that its overall "adequacy" in achieving Community objectives can then be compared with that of the proposed Community measure, as the principle of subsidiarity requires. ${ }^{225}$ Subsidiarity plainly calls for predictions and therefore for the

224. Non-implementation of Community directives by the Member States has been a longstanding problem in the Community.

225. It is obvious that terms like "adequacy" (or "efficacy," "sufficiency" or "necessity"), in which the definition of subsidiarity is invariably couched, tend to mask the elements of subjectivity and judgment entailed in a decision by the Community to take action in place of the Member States. "As with ... other reform initiatives [like decentralization, delegation and deregulation], real difficulties arise in interpreting and applying the general principle in practice. The definition [of subsidiarity] begs the important questions about what is 'appropriate' and what is 'unnecessary." Metcalfe, supra note 2 , at $14-15$. 
exercise of judgment on matters that may be at best the subject of ignorance and conjecture, and at worst the subject of bitter dispute.

The fact that subsidiarity calls for judgments that are invariably political and often immensely speculative is not, however, an argument against requiring the institutions to observe it. Neither is the fact that the analysis may rarely yield obvious results. As I argue in greater detail in a later section on the Court of Justice, ${ }^{226}$ the essential question is whether such a requirement will help the institutions to reach politically sound decisions, while avoiding the imposition on them of undue procedural costs.

3. Subsidiarity and Proportionality. - As noted earlier, ${ }^{227}$ the European Council at Edinburgh underscored the close affinity between the Community law principles of subsidiarity and proportionality. It regarded the former as dealing with the question whether the Community should take action, and the latter as dealing with the Community's choice of means when it does act. In this section, I argue that the relationship between the two concepts is not as simple as the European Council suggests. I shall attempt to show that proportionality does not simply "pick up" where subsidiarity "leaves off," and that this in turn has serious implications for the political branches and the Court of Justice alike.

The doctrine of proportionality, which the Court of Justice largely derived from continental principles of constitutional and administrative law, ${ }^{228}$ is said to require that every Community measure satisfy three related criteria. First, the measure must bear a reasonable relationship to the objective-presumably a legitimate one-that the measure is intended to serve. 229 This may be regarded as the doctrine's "rationality" component. Second, the costs of the measure must not manifestly outweigh its benefits. ${ }^{230}$ This may in turn be regarded as the doctrine's "utility" component. Finally, the measure chosen must represent the solution, among the various alternatives that were available for achieving the prescribed objective, that is least burdensome. ${ }^{231}$ This requirement to use the "least restrictive" or "least drastic" means is one that the Court

226. See infra notes $237-255$ and accompanying text.

227. See supra notes $155-159$ and accompanying text.

228. See Jochen Abr. Frowein, The European Community and the Requirement of a Republican Form of Government, 82 Mich. L. Rev. 1311, 1322 (1984) (view of the doctrine of proportionality as having been influenced by German constitutional practice); see also Stein, supra note 55 , at $14 \& \mathbf{n} .48$ (general principles of Community law [including proportionality] were derived from the general principles of law in force in the Member States).

229. See, e.g., Case Relating to Certain Aspects of the Laws on the Use of Languages in Education in Belgium (Series A, No. 6), 1 Eur. H.R. Rep. 252, 254, 293 (1968); see also Philis v. Greece (series A, No. 209), 13 Eur. H.R. Rep. 741, 765 (1991).

230. See Case C-331/88, Regina v. Minister of Agriculture, Fisheries and Food, ex parte Fédération Européenne de la Santé Animale (FEDESA), [1991] 1 C.M.L.R. 507, 532-33.

231. See Case 31/59, Acciaieria e Tubificio di Brescia v. High Authority of the European Coal and Steel Community, 1960 E.C.R. 71; see also Case 255/84, Nachi Fujikoshi Corp. v. Council, 1987 E.C.R. 1861, 1871-72, 1893-95, [1989] 2 C.M.L.R. 76, 105. 
of Justice has typically justified in terms of minimizing the burdens imposed by the Community on the private sector, but it can readily be used to minimize the Community's intrusions on the Member States and their subcommunities as well. Each of the three elements of proportionality has at least some resonance among levels of judicial scrutiny recognized in U.S. constitutional review.

Proportionality in fact has chiefly been regarded in the European Community, and in European public law more generally, as a principle of judicial review. Within the Community, it is the Court of Justice that has developed and enforced the notion that Community measures must bear a reasonable relation to the end sought to be achieved, must produce a net benefit, and must represent the least burdensome means available, and that they will in principle be annulled if they fail to do so. ${ }^{232}$ This is not to say that the political branches-notably the Commission, Parliament, and Council-do not consider proportionality in making their legislative judgments; it is to be hoped and possibly even assumed that they do, as an integral part of their deliberative processes.

Nevertheless, the Maastricht Treaty ${ }^{233}$ and, even more explicitly, the guidelines of the 1992 Edinburgh Council ${ }^{234}$ have the distinct merit of

232. See, e.g., Case 11/70, Internationale Handelsgesellschaft $\mathrm{GmbH}$ v. Einführ- und Vorratsstelle für Getreide und Futtermittel, 1970 E.C.R. 1125, 1135-38 [1972] 10 C.M.L.R. $255,284-87$.

233. See supra notes 41,158 .

234. According to the European Council at Edinburgh, Article 3b of the Maastricht Treaty incorporates the principle of proportionality, defined as requiring "that the means to be employed by the Community should be proportional to the objective pursued." Edinburgh Conclusions, supra note 11, at 2.

The Edinburgh guidelines specific to proportionality include the following:

ii) Any burdens, whether financial or administrative, falling upon the Community, national governments, local authorities, economic operators and citizens, should be minimised and should be porportionate to the objective to be achieved.

iii) Community measures should leave as much scope for national decision as possible, consistent with securing the aim of the measure and observing the requirements of the Treaty. While respecting Community law, care should be taken to respect well established national arrangements and the organisation and working of Member States' legal systems. Where appropriate and subject to the need for proper enforcement, Community measures should provide Member States with alternative ways to achieve the objectives of the measures.

iv) Where it is necessary to set standards at Community level, consideration should be given to setting minimum standards, with freedom for Member States to set higher national standards ... . where this would not conflict with the objectives of the proposed measure or with the Treaty.

v) The form of action should be as simple as possible, consistent with satisfactory achievement of the objective of the measure and the need for effective enforcement. The Community should legislate only to the extent necessary. Other things being equal, directives should be preferred to regulations and framework directives to detailed measures. Non-binding measures such as recommendations should be preferred where appropriate. 
clarifying that proportionality is not only a judicial doctrine for the Court of Justice to apply in reviewing the legality of Community action, but also a legislative doctrine for the political branches to follow in their policymaking. Because the Community institutions are thus duty bound to observe both proportionality and subsidiarity as general principles of decision-making, they have an interest in knowing whether and to what extent the two are consistent. The Maastricht Treaty suggests that they are of a piece. ${ }^{235}$ The Edinburgh guidelines go further, implying that once subsidiarity determines that the Community should take action, proportionality then dictates the action it should take. ${ }^{236}$ The suggestion is that the two naturally function in concert, even in logical sequence. These assumptions about subsidiarity's natural relationship with proportionality bear closer scrutiny.

It seems reasonably clear that a measure may satisfy the first two criteria of proportionality and nevertheless run afoul of subsidiarity. In other words, a Community measure, while reasonably related to its stated purpose and productive of net benefits, may nevertheless not have been necessary, in the sense that action taken at the Member State level, or perhaps non-regulation altogether, would have been quite effective in achieving the Community's goals. The relationship between subsidiarity and the "least drastic means" aspect of proportionality is thus potentially problematic. Suppose, for example, that the least burdensome approach to accomplishing a given objective would be through Community action rather than through some alternative action at or below the Member State level. In this event, subsidiarity and proportionality would in a sense work at cross-purposes, with subsidiarity dictating a disproportionate remedy (assuming the objective could be achieved at or below the Member State level) and proportionality in turn dictating a remedy that fails the test of subsidiarity. It is difficult to say, as an abstract matter, whether proportionality or subsidiarity should carry the day.

One way of dealing with this tension would be for the institutions to take the European Council rigorously at its word and not entertain the proportionality question until the subsidiarity question is settled. Under this strategy, the Community institutions would refrain from adopting

Consideration should also be given where appropriate to the use of voluntary codes of conduct.

vi) Where appropriate under the Treaty, and provided this is sufficient to achieve its objectives, preference in choosing the type of Community action should be given to encouraging cooperation between Member States, coordinating national action or to complementing, supplementing or supporting such action.

vii) Where difficulties are localized and only certain Member States are affected, any necessary Community action should not be extended to other Member States unless this is necessary to achieve an objective of the Treaty.

Id. at 8-9.

235. See supra notes $155-159,234$ and accompanying text.

236. See Edinburgh Conclusions, supra note 11, at 8-9. 
any measure whenever their objectives could adequately be met through action taken at or below the Member State level. The fact that a Community-level measure might impose fewer burdens, and thus constitute a less drastic means to the same end, might never enter into consideration. Such a solution may justly be criticized as sacrificing proportionality on the altar of subsidiarity and, in the process, forsaking many of the efficiency advantages of Community-level action.

An obvious alternative would be to posit that subsidiarity requires resort to Member State (or more local) action over Community action only when it would be just as effective. If action at or below the Member State level would impose greater burdens than Community action, and to that extent fail the test of proportionality, then by definition it is not equally effective. By this reasoning, strictly applied, subsidiarity would simply not require that the Community refrain from acting, and proportionality considerations alone would in effect have dictated the result. Of course, if subsidiarity never deters the Community in such situations from taking the action that proportionality favors, it is then the principle of subsidiarity that will find itself systematically sacrificed.

It thus seems clear that at least under some circumstances subsidiarity and proportionality, strictly applied, will point in opposite directions. Realistically, the political branches of the Community have a means of escape from the apparent dilemma. They can relax the proportionality test so as to accept Member State action in lieu of Community action, even if the former is more burdensome, provided it is not manifestly so (i.e., does not impose unreasonably excessive additional burdens); this opens up the possibility of scoring large subsidiarity gains for a small proportionality price. Conversely, they can relax the subsidiarity test; if the proportionality advantages of Community action over Member State action are substantial enough, subsidiarity's preference for localism arguably should not be allowed to stand in the way.

What I am here describing, and what seems to me to make a good deal of sense if both subsidiarity and proportionality are to be taken seriously, is of course the possibility of making different tradeoffs between the two. Analysis and reflection may show that a Member State course of action does far more harm from a proportionality point of view than it does good from a subsidiarity point of view or, conversely, that a Community measure does far more harm from a subsidiarity point of view than it does good from a proportionality point of view. Only some kind of "comparative impairment" analysis will reveal how much is being paid in proportionality terms for subsidiarity gains, or vice versa. Resolving the tension between subsidiarity and proportionality, when the two are in competition with each other and when each may plausibly be applied to the matter at hand, can only be described as an acutely political judgment to be made by the political institutions themselves. They are the ones best situated to determine whether, in light of all the interests at stake in 
the matter at hand, it is more important to promote the values of localism or to deploy the least drastic means.

\section{Subsidiarity and the Court of Justice}

My discussion of subsidiarity thus far has proceeded with its implications for judicial review still very largely in the background. Given subsidiarity's fundamentally political character, this is appropriate. In fact, the drafters at Maastricht sidestepped the question of whether and to what extent the principle of subsidiarity would be justiciable. ${ }^{237}$ When the European Council finally addressed the question at Edinburgh in 1992, it displayed deep ambivalence, declaring, on the one hand, that subsidiarity "cannot be regarded as having direct effect," but, on the other, that "compliance with it by the Community institutions [is] subject to control by the Court of Justice."238 Under this view, while individual litigants in national courts might not be permitted to invoke the principle of subsidiarity to avoid the application of otherwise valid Community measures, legal challenges to Community measures could be brought on subsidiarity grounds directly in the Court of Justice. Because standing to sue in the Court of Justice is highly restrictive, ${ }^{239}$ and because the statute of limitations on such actions is in any event extremely short, ${ }^{240}$ the Council's solution appears to make the principle of subsidiarity justiciable without at the same time opening the floodgates. The fact remains,

237. The European Parliament, and more particularly its Committee on Institutional Affairs chaired by Giscard d'Estaing, concluded that the Court of Justice should consider the principle of subsidiarity to be justiciable. See European Parliament Committee on Institutional Affairs, Interim Report on the Principle of Subsidiarity, Eur. Parl. Doc. A3163/90 (June 22, 1990), discussed in Cass, supra note 2, at 1133; European Parliament Committee on Institutional Affairs, Report on the Principle of Subsidiarity, Eur. Parl. Doc. A3-267/90. Some academic commentators agree. See, e.g., Lenaerts, supra note 80, at 133; Reimut Jochimsen, Subsidiarity in the Area of Economic and Monetary Union, in Subsidiarity: The Challenge of Change, supra note 6 , at 73,76 . Others, including a former president of the Court of Justice, consider the principle of subsidiarity to be nonjusticiable. See, e.g., Lord Mackenzie-Stuart, Assessment of the Views Expressed and Introduction to a Panel Discussion, in Subsidiarity: The Challenge of Change, supra note 6 , at 37, 41. For a similar expression of views, see Gretschmann, supra note 27, at 58-59.

238. Edinburgh Conclusions, supra note 11, at 4; see also supra notes 149-150 and accompanying text. The institutions were equally tentative on the subject in the interinstitutional agreement they signed at Luxembourg in October 1993. See Interinstitutional Agreement, supra note 199. They agreed that compliance with the subsidiarity principle "shall be reviewed under the normal Community process, in accordance with the rules laid down by the Treaties." Id. at III(1).

In its recent ruling affirming the constitutionality of Germany's ratification of the Maastricht Treaty, the German Constitutional Court likewise assumed that the Court of Justice would enforce the principle of subsidiarity and suggested that subsidiarity's success in preserving the authority of the Member States would very largely depend on the Court of Justice's subsidiarity case law. See German Constitutional Court Maastricht Decision, supra note 20 , at $82-83$.

239. See supra note 150 .

240. See supra note 150 . 
however, that even under the Court of Justice's strict standing and limitations rules, every Community measure would be subject to attack in the Court of Justice on subsidiarity grounds by a Community institution or by one or more of the Member States politically opposed to it. ${ }^{241}$

1. Subsidiarity as a Procedural and Substantive Norm. - Assuming justiciability, the principal question of judicial review is whether the Court of Justice should treat subsidiarity primarily as a substantive or a procedural requirement. I suggest that casting subsidiarity in procedural rather than substantive terms will best allow the Court of Justice to promote respect for the values of localism without enmeshing itself in profoundly political judgments that it is ill-equipped to make and ultimately not responsible for making. The same characteristics that make the inquiry difficult for the political branches to conduct-namely, uncertainty about how much localism really matters on a given issue, the heavy reliance on prediction and the probabilities of competing scenarios, the possibility of discretionary tradeoffs between subsidiarity and proportionality, and the sheer exercise of political judgment entailed-make the inquiry even more problematic for the Court. Even without inserting itself unduly into those matters, however, the Court can seek to verify whether the institutions themselves examined the possibility of alternative remedies at or below the Member State level. That very inquiry should encourage the political institutions to structure their discussion and focus their debate on the most central legislative task, namely identifying the measures, if any, that will appropriately address the problems worth addressing, and suggesting the level of government at which (and ultimately the form in which) those measures should be taken. This in turn should promote a realistic assessment by the political branches of the costs and benefits of Community action and inaction alike. Moreover, a decisional process which demonstrates that the institutions genuinely considered the available Member State alternatives before resolving to act is likely to win measurably greater trust and thus enjoy greater support among the Member States and European public opinion than one that does not. What little evidence we have suggests that the institutions can meaningfully address the questions that subsidiarity raises, ${ }^{242}$ and that addressing those ques-

241. The notion that subsidiarity might be enforceable by the Court of Justice in direct actions challenging Community measures but not enforceable via direct effect in national courts is an awkward and unprecedented one. Even critics of subsidiarity assume that, under Maastricht, challenges to such measures on subsidiarity grounds will be the proper subject of preliminary references to the Court of Justice and preliminary rulings by the Court. See, e.g., Toth, supra note 5, at 1101-02.

242. Once subsidiarity gained political prominence during the discussions leading up to the latest reform of the Community treaties, it apparently began to influence the institutions' legislative action. "Anticipating the future, the principle has already made its appearance in the preparation of new policy programmes and legislation in the Community ... [T] here is scarcely a proposal by the Commission or other groups ... which is not tested against the principle of subsidiarity." P.J.C. Kapteyn, Community Law and the Principle of Subsidiarity, Revue des Affaires Européennes 35, 35 (1991). 
tions influences outcomes. ${ }^{243}$

The efficacy of a procedural review of this sort should not, of course, be exaggerated, particularly since there are limits to the resources that the Court of Justice can or should expend in verifying whether the political branches actually inquired into subsidiarity and whether the inquiry was a genuine one. Determining the minimal adequacy of a "subsidiarity impact analysis" is inherently problematic, but the Court's performance in enforcing the rather elusive proportionality principle ${ }^{244}$ suggests that it may be capable of drawing the necessary lines. The Court should not attempt to police closely the performance of such analyses; one can hope that the mere prospect of the Court policing their performance will cause the political branches to perform the required examinations more seriously. If the values that the subsidiarity inquiry can be expected to serve-self-determination and accountability, personal liberty, flexibility, preservation of local identities, diversity, and respect for the internal divisions of component states-are important enough (as I believe they are), and if the costs of the inquiry are not too great (as I believe they are not), then the Court of Justice should require that it be made.

It is easy in conceiving of subsidiarity as a procedural principle to envisage the Community institutions satisfying themselves that Community action is necessary and then proceeding to act. However, in order to assess fully the merits of subsidiarity, it is also important to contemplate the situation in which the institutions ultimately refrain from action because they conclude that the Member States, left to their own devices, can effectively accomplish the Community's purposes, and to assess the risks of the institutions acting on that belief. ${ }^{245}$ More specifically, the institutions may decline to act, but later be shown to have erred in their judgments about the Member States' willingness or capacity to address the problem at hand. The Member States may turn out not to have acted as expected, or their actions may turn out not to have produced the desired consequences. In theory, at least, the institutions' subsidiarity analyses

243. See supra notes $192-198$ and accompanying text.

244. See Case 47/86, Roquette Frères SA v. Office National Interprofessionnel des Céréales, 1987 E.C.R. 2889; see also Case 122/78, S.A. Buitoni v. Fonds d'Orientation et de Régularisation des Marchés Agricoles, 1978 E.C.R. 677.

245. For example, the Commission recently observed that the existing differences among national laws governing the illegal possession and use of drugs, though real, were "grossly exaggerated and overestimated":

The national laws of the Twelve are consistent with regard to drug trafficking, which is prohibited in all of the Member States. A few minor differences exist with regard to the possession of drugs: in Spain, Italy and the Netherlands [for example], this is tolerated for strictly personal use as part of policy to reintegrate drug addicts.

The Commission thus concluded that "There is . . . no need for harmonization of the national laws [on the subject], this being governed by the principle of subsidiarity." National Implementing Measures; Removal of Tax Frontiers; Narcotic Drugs and Psychotropic Substances; Do National Laws on Drugs Differ? (Commission of the European Communities INFO-92) (July 13, 1993). 
should furnish a basis for the Commission to compare what actually happened in the wake of the Community's decision not to act with what the institutions thought would happen. If the Commission decides that the Community should intervene after all, it may even find that the existing record assists it in determining the specific measures to propose.

Permitting judicial challenges to Community measures on substantive subsidiarity grounds would certainly raise at least as many difficulties as permitting them on procedural grounds. It is clear that the Court should not in any event conduct a de novo inquiry into the comparative efficacy of Community and Member State action in achieving the Community's objectives. The Court should not even conduct a de novo review of the existing legislative "record." As we have seen, the probabilities to be assigned to the various Member State alternatives, the assessment of their utility in achieving Community goals, and a comparison with them of the Community measure in question are matters of political judgment, precisely the kind on which the Court should show the utmost deference to the political branches. The case for deference becomes positively overwhelming when it appears that the institutions may also have had to balance subsidiarity and proportionality considerations-each with its own separate complexities-against one other. ${ }^{246}$

Imagine for example a situation in which the Council of Ministers, facing a problem within the Community's sphere of competence, determines upon study that each plausible option at the Member State level presents certain inconveniences and disadvantages significant enough to justify the Community acting in their stead. A considered judgment that the Member State alternatives are deficient, and that Community action is therefore necessary, will hardly be easy to refute. To refute it might require gauging everything from the technical and policy bases of the institutions' assumptions to the inherent logic and persuasiveness of their analysis, not to mention the importance of vindicating the subsidiarity principle (and thereby the values of localism) on the particular issue at hand. If, as I urge, subsidiarity is in fact taken seriously as a tool of legislative analysis, the Council's conclusion that Member State action would not adequately achieve Community goals should scarcely ever be so conclusory or unconvincing as to invite disbelief by the Court.

It has been argued that if the prospect of successfully challenging a Community measure on subsidiarity grounds is indeed so slim, then the subsidiarity principle may just as well be considered categorically nonjusticiable, and the Court spared the agony of dealing with it.247 The German Constitutional Court has in effect determined that the largely comparable provisions on federal subsidiarity in the German Constitution $^{248}$ are nonjusticiable, with the result that the "necessity" for federal

246. See the discussion of subsidiarity and proportionality, supra notes 227-236 and accompanying text.

247. See, e.g., Kapteyn, supra note 242 , at $51-42$.

248. See Grundgesetz [Constitution], art. 72 (Germany). 
government legislation in areas of concurrent competence is essentially a political question to be decided by the political branches without judicial interference. ${ }^{249}$ But deference to the political branches on subsidiarity does not require that the principle be made wholly nonjusticiable, any more than deference on proportionality requires that result. The mere possibility that the Court will find the Community to have egregiously overstated the risks of leaving a matter in Member State hands, ${ }^{250}$ and will annul its exercise of power, should induce the Community's political branches to exercise sound judgment in this respect. 251

Treating subsidiarity as a justiciable principle, whether procedural or substantive, will admittedly require the Court of Justice to play a role to which it is not accustomed, namely restraining Community action in the interests of localism. ${ }^{252}$ Nevertheless, the Court has shown itself to be capable of reviewing the legality of Community measures by reference to other constitutional values that could equally be described as "vague but not intelligible," 253 and for which precise criteria of judgment do not exist. One could cite the Court's jurisprudence on fundamental rights, ${ }^{254}$ though that is a somewhat different case, since courts tend to regard protecting such rights as their special calling. The Court of Justice's proportionality jurisprudence-marked by a high degree of deference to the political branches, but also by an occasional annulment of one of their decisions-provides a closer analogy. ${ }^{255}$ The fact remains that the Com-

249. The German Constitutional Court has ruled that " $[t]$ he question whether there exists a necessity for federal legislation is a question of due judgment on the part of the federal legislature, which is by its very nature nonjusticiable and therefore fundamentally removed from examination by the Court." Judgment of Apr. 22, 1953, 2 BVerfGE 213, 224; see also Judgment of July 15, 1969, 26 BVerfGE 338, 382-83; Judgment of Nov. 22, 1983, 65 BVerfGE 283, 289; Judgment of Oct. 9, 1984, 67 BVerfGE 299, 327; Judgment of June 8, 1988, 78 BVerfGE 249, 270; see generally Emiliou, supra note 17, at 404; Everling, supra note 2, at 1070-71; Eric J. Finseth, "Subsidiarity" and the Future of European Federalism (Feb. 12, 1993) (unpublished manuscript, on file with the Columbia Law Review).

250. I do not deal here with the opposite situation, in which the institutions allow the states to act in aid of a Community objective when the institutions could have achieved that objective more effectively themselves. See George A. Bermann, Subsidiarity and the European Community, 17 Hastings Int'l \& Comp. L. Rev. 97, 107-08 (1993).

251. See Emiliou, supra note 17. Emiliou urges the Court to restrict itself to a "'marginal review" of subsidiarity, that is review for "a patent error or . . . a misuse of powers." Id. at 405 (footnotes omitted). For a parallel argument in favor of "marginal" judicial review of Congress' respect for the Tenth Amendment, see Richard B. Stewart, Pyramids of Sacrifice? Problems of Federalism in Mandating State Implementation of National Environmental Policy, 86 Yale L.J. 1196, 1271-72 (1977).

252. Weiler observes that, while the Court not infrequently has struck down measures of the Council or Commission, "[it has never] in its entire history ... struck down a Council or Commission measure on grounds of Community lack of competence." See Weiler, Transformation, supra note 20, at 2447.

253. See supra note 2 and accompanying text.

254. See generally Bermann et al., supra note 13, at 129-49; Koen Lenaerts, Fundamental Rights to be Included in a Community Catalogue, 16 Eur. L. Rev. 367, 372 (1991) (citing cases).

255. See supra note 244 and accompanying text. 
munity simply cannot afford to ignore the political impulses that fueled the demand for subsidiarity in connection with the Treaty on European Union and that the Community's prospective enlargements will only heighten. In this context, the Court of Justice has a crucial symbolic and educational-albeit operationally limited-role to play.

2. The Strength of the Political Safeguards of Subsidiarity. - The decision whether to assign the judiciary a role in policing legislative respect for subsidiarity, and if so what role, is evidently a highly problematic one. In Part III of this Article, I examine prevailing attitudes toward the problem in the United States. A factor that has seemingly influenced the outcome in the United States is the strength of the theory that the structure and composition of the federal government itself furnish adequate political safeguards for federalism. As we shall see, ${ }^{256}$ confidence in the adequacy of these safeguards has come under increasing pressure in the United States, with the result that the Supreme Court has only recently shown a revived interest in judicially enforcing the Tenth Amendment. It may therefore be useful in confronting the uneasy prospect of making subsidiarity justiciable in the Community to try to assess the political safeguards of federalism in the EC institutional setting. ${ }^{257}$ My conclusion is that, whatever the strengths of the theory of political safeguards in the United States, the theory fits the Community rather poorly.

Superficially, the Council of Ministers exhibits precisely the kind of structure that should enable it to safeguard the political interests of the States. ${ }^{258}$ Each Member State is separately represented in the Council by the government minister responsible for the field in which the Council is considering action. The minister's acknowledged responsibility is to look after the State's interests in the matter before the Council and to cast a vote accordingly.

The fact that a minister represents the interests of a Member State does not, however, mean that he or she will necessarily vote in a manner consistent with the principle of subsidiarity or the purposes underlying it, that is, the notion that policymaking discretion should be left in the most local hands possible. The more common assumption is that Member

256. See infra notes 334-351 and accompanying text.

257. For an interesting comparative discussion of the United States and European Community with respect to the political safeguards of federalism, see Lenaerts, supra note 10 , at 258-62. Lenaerts cites "the political reality that decision-making within the American Union is organically independent from the States, whereas in the European Community the Member States themselves play the double role of participants in the Community decision-making and of antipodes to the legal order of the Community as such." Id. at 262.

258. See supra note 15. On the "central role of the Member States in the Community system," see Dehousse, supra note 132, at 390-92. Furthermore, the Community has many fewer financial resources in relation to the Member States than the federal government in the United States has in relation to the American States. The relative lack of Community resources naturally limits the Community's activities, notably its ability to implement Community law and policy without the aid of the Member States. See id. at 388-89. 
State representatives will vote in the Council in accordance with their State's economic and political advantage as they see it in the context of the issue at hand.259 A particular policy may be so economically or politically favorable to a Member State that it wins the State's support in the Council, despite the fact that the policy's underlying objective could adequately be accomplished by action taken at or below the Member State level. In this respect, subnational regions may be among those most disadvantaged by the transfer of national regulatory authority to the Community institutions. ${ }^{260}$ Even if authority over a matter could perfectly well be left in Member State hands, a State may support action at the Community level simply in order not to be seen as voting on subsidiarity grounds against a measure that it basically favors. A State may also support the adoption of a Community measure precisely to avoid suffering the competitive disadvantages that would result from taking an equally appropriate measure on its own or in the company of a minority of States. Shifting decisional authority to Brussels may even enable a national government to escape political responsibility for a necessary but highly unpopular measure; political accountability will certainly not thereby be served.

Under each of these hypotheses, a representative's vote in the Council, though in a sense dictated by the Member State's interest, will fail to reflect the various political advantages of localism-self-determination and accountability, personal liberty, flexibility, preservation of identities, diversity and respect for internal divisions of component States-that are associated with subsidiarity. ${ }^{261}$ Moreover, the intergovernmental flavor of Council decision-making, even under qualified majority voting, should never be underestimated. Wherever a Member State's narrow political interests in a given matter may lie, its representative may readily decide that the overriding interest of another State (or, to put the matter more squarely, the desirability of serving another State's interests in exchange for its political favor on some other issue) requires that he or she vote otherwise. In a decisional setting so clearly marked by interstate political negotiation, the abstract advantages of reserving political choice to local communities may well be overlooked. For all these reasons, a Member State's representative in the Council of Ministers may simply not cast his or her vote in keeping with the notion that power should be exercised at the lowest political level at which the objective of the exercise can be accomplished, and possibly not even in keeping with the political interests of the populations and subpopulations within his or her State.

259. See, e.g., Gretschmann, supra note 27 , at 45,57 .

260. "[T]he regions now increasingly see Europe as a threat to their autonomy. They try to devise methods for participating more effectively in the Community decision making process, but the central State apparatus is reluctant to give up its privileged position in this respect." De Witte, supra note 28, at 13 (citing Germany, Belgium, Spain, Italy and prospective Member States like Austria and Switzerland).

261. See generally Making Sense, supra note 21, at 53 . 
The weakness of the Council in terms of domestic political accountability has in fact become a preoccupation in certain Member States, particularly as the Community's powers of governance have grown. Denmark, for example, has pioneered techniques of national parliamentary oversight of the Government's voting patterns in the Council of Ministers. ${ }^{262}$ The French Constitution was amended in 1992 in contemplation of the Maastricht Treaty to ensure that the French Parliament would be consulted on the exercise of legislative powers by the Council. ${ }^{263}$ As a federal state itself, Germany recently amended its Constitution to guarantee that the Länder would actually have a decisive role in at least some of the votes that Germany casts in the Council; ${ }^{264}$ and the

262. The Danish government, as part of Denmark's constitutional monarchy, is answerable generally to its national parliament, the Folketing. Because Danish governments are typically minority governments, dependent on the cooperation of rival parties, it is often necessary to put politically volatile issues to the Folketing for approval before taking action.

263. A new Article 88-4 was added to the French Constitution in June 1992. It provides:

The Government shall submit to the National Assembly and to the Senate all proposals for Community measures that contain provisions on subjects ordinarily governed by the [French] Parliament no later than the time when those proposals are presented for consideration to the Council of Ministers of the Communities. 264. As replaced in 1992, Article 23 of the German Basic Law provides in part: (1) For the realization of a united Europe, the Federal Republic of Germany may participate in the development of a European Union which is bound by the principles of democracy, legality, social responsibility and federalism and by the principle of subsidiarity, and which guarantees a protection of fundamental rights that is essentially comparable to this Basic Law. The Federation may for this purpose transfer sovereign rights through legislation enacted with the approval of the Bundesrat....

(2) The Bundestag and, through the Bundesrat, the States shall participate in matters of the European Union. The Federal Government must inform the Bundestag and the Bundesrat fully and at the earliest possible point in time.

...

(4) The Bundesrat shall be given a part in the formation of the political will of the Federation, to the extent that it would have to participate in a corresponding domestic law measure or to the extent that the States would enjoy internal competence.

(5) Insofar as a matter of exclusive federal jurisdiction may affect the interests of the States, or insofar as the Federation otherwise has legislative competence, the Federal Government shall take account of the positions of the Bundesrat. When, in the core of the matter, the legislative competences of the States, the organization of their agencies, or State administrative procedures are affected, the point of view of the Bundesrat shall to that extent be given dominant consideration in the formation of the political will of the Federation ....

(6) Whenever the exclusive legislative competences of the States are affected in their core, the exercise of the rights which the Federal Republic enjoys as a Member State of the European Union should be entrusted by the Federation to a representative of the States named by the Bundesrat. These rights shall be exercised with the participation and in concertation with the Federal Government. The national political responsibility of the Federation will thereby be safeguarded. 
German Constitutional Court's recent affirmance of the constitutionality of the Maastricht Treaty seems to be conditional on the Länder having effective opportunities to participate in Council decision-making. ${ }^{265}$ These various strategies for heightening the responsiveness and accountability of Member State representatives in the Council, however, are still poorly developed ${ }^{266}$ and have yet to prove their efficacy. ${ }^{267}$

The claim that the structure and composition of the Community institutions guarantee respect for subsidiarity is not much stronger in the case of the Commission or the European Parliament. The Commission, whose role in drafting and proposing Community legislation is paramount, does not even purport to act in the interests of the States, much less in the interest of the political autonomy of their subcommunities. Commissioners are in fact expressly barred by the Treaty from doing so. ${ }^{268}$ In short, the Commission may choose to design legislation in the spirit of subsidiarity, but nothing in its structure or composition so dictates.

The European Parliament offers greater institutional promise in this respect. Its members are popularly elected by territorially-defined constituencies from among the Member States. As such, they are or should be in closer touch with the local populations and their aspirations for selfgovernance. Judging by the broad subsidiarity language that Parliament included in its 1984 Draft Treaty on European Union, ${ }^{269}$ subsidiarity indeed has some resonance in that institution. On the other hand, seats in

Grundgesetz [Constitution] art. 23 (Germany). Even prior to the constitutional amendment, the Federal Government of Germany followed the practice of consulting the German States before voting in the Council on legislation of interest to them. For a current example of such consultation in practice, see EC Paves the Way for Single Market in Medicines, Reuters News Service-Western Europe (June 14, 1993) available in LEXIS, Reuters Textline (reporting Germany's delay of the Council's vote on the creation of a Community-wide medicines evaluation agency in order first to consult the German Länder on the subject).

265. German Constitutional Court Maastricht Decision, supra note 20.

266. See generally De Witte, supra note 28 , at 8 ("While governments have been able to compensate some of the powers they lost by their participation in the Community decision-making process through the Council, national parliaments appear as the net losers in the new institutional equilibrium."); see also The European Community: Upsizing: The Difficulty of Growing Bigger Gracefully, The Economist, July 3, 1993, at 18-19 (describing national parliamentary scrutiny of proposed EC laws as traditionally "cursory"). The European Council urged at its Lisbon Summit of June 1992 that the "dialogue" between the national parliaments and the European Parliament be "strengthened." See European Council in Lisbon, Conclusions of the Presidency, June 26-27, 1992.

267. See Dehousse \& Weiler, supra note 109, at 294. On the need for more creative use of "networks" between Member State constituencies and the Community institutions, see generally Metcalfe, supra note 2. On the increasing burdens on the Commission in particular, and on the Commission's "management deficit," see Les Metcalfe, After 1992: Can the Commission Manage Europe?, 51 Aust. J. Pub. Admin. 117 (1992).

268. See EC Treaty art. 157.

269. See supra note 35 and accompanying text. 
the European Parliament have chiefly attracted persons in search of a platform for the advancement of more or less well-defined political views or philosophies rather than the representation of local interests as such. ${ }^{270}$ Significantly, parliamentarians sit, and vote, according to broad cross-national party affiliations, not according to national or subnational geographic criteria. The notion that a politically neutral value ${ }^{271}$ like subsidiarity would play a determining role in the votes cast by members of Parliament elected and organized in this fashion is not a very realistic one. Finally, Parliament's legislative functions are still quite limited. On some subjects, its voice is consultative or advisory only; on others its opposition to a bill simply requires that the Council pass the measure by unanimity rather than qualified majority, or forces a "second reading."272 Only under the Maastricht Treaty, and even then only on matters that are expressly made subject to "parliamentary co-decision," 273 does Parliament enjoy something in the nature of a legislative veto.

All in all, the institutional support for a theory of political safeguards of subsidiarity in the European Community is not very impressive. ${ }^{274}$ Despite appearances, neither the Council of Ministers nor the Parliament is structured to ensure that political decisions on any given issue are made at the lowest level of government possible; the Commission is certainly not so structured. Arguably, the real institutional safeguard of subsidiarity in the Community is that, in most areas, the implementation of Community policy ultimately lies in the hands of Member State and local officials. ${ }^{275}$ Thus, states and localities have it within their power to influence the ways in which, and the efficacy with which, Community policy is actually administered. Unless the Community acquires much greater fiscal independence from the Member States than it now has, which is not in the offing, this situation is unlikely to change.

The argument that the decentralized administration of Community law favors subsidiarity is, however, deeply flawed. Besides confusing the notions of making and executing policy, the argument only suggests that States and localities may weaken the enforcement of policies made at an inappropriately high level of government, not that they will do so, and certainly not that they will do so with any consistency. In fact, the whole-

270. See Alberta M. Sbragia, The European Community: A Balancing Act, 23 Publius 23, 33 (1993); Alberta M. Sbragia, From 'Nation State' to 'Member State': The Evolution of the European Community (Oct. 1993) (unpublished manuscript, on file with the Columbia Law Review).

271. Subsidiarity is assumed to be neutral from a policy point of view. It is obviously not neutral from a federalism point of view.

272. I refer to the so-called "parliamentary cooperation procedure." See supra note 134.

273. See supra note 134 .

274. See Haagsma, supra note 88 , at $358-59$.

275. T. Koopmans, Federalism: The Wrong Debate, 29 Common Mkt. L. Rev. 1047, 1048 (1992). This reliance is due at least in part to the Community's severely limited resources in comparison with those of the Member States. See supra note 258. 
sale reliance on Member State resources for the implementation of Community policy may raise more subsidiarity doubts than it allays. As we shall see in Part III, ${ }^{276}$ the U.S. Supreme Court has come to view federalism as being ultimately impaired when the public cannot hold its elected officials politically responsible for the policy decisions they carry out, or even determine the priorities according to which public resources are spent. Yet this is precisely the situation in the Community law system: Member State officials regularly implement policies they had little or no role in making.

3. Subsidiarity and the Direct Effect of the EC Treaty. - Most discussions of subsidiarity-and this Article thus far is no exception-treat the Court of Justice's interest in the principle as limited to deciding whether and to what extent to police the political institutions' respect for subsidiarity. My view on this question is clear; I believe the Court should treat the principle as a legally enforceable procedural mandate to the institutions, while at the same time paying pronounced deference to their judgments on the substance of the matter. But the Court should not consider that it discharges its responsibilities with respect to subsidiarity simply by conducting this limited monitoring of the Community's political branches. The demand for subsidiarity among Europeans has been fueled not only by the perception of legislative excess on the part of the Commission and Council, but also by the perception, at least among those aware of the Court of Justice's role in legal integration, of judicial excess on the Court's own part. 277

The question, put bluntly, is whether the Court of Justice, through its own understandably vigorous demands for legal integration over the years, has contributed to a sense of erosion of local political autonomy, and possibly violated the principle of subsidiarity itself. This question is worth raising if only because the Court may have difficulty pressing subsidiarity on the political branches, either as a procedural or a substantive requirement, unless it shows a willingness to examine its own jurisprudence from a subsidiarity point of view. Consider, for example, the question of the direct effect of Article 30 of the EG Treaty concerning the free movement of goods. Surely when the Court rules that a Member State may not, in conformity with the principle of free movement, regulate the intrastate marketing of a particular good in the interest of consumer or environmental protection, public health, public morality and the like, it is itself in effect taking action at the Community level and preventing action at the Member State level, albeit in the name of the Treaty. But for the fact that the intervention is judicial rather than legislative, and is alleged to flow directly from the Treaty rather than from a grant of authority by the Treaty, the conditions for application of the principle of subsidiarity would seem to be present.

276. See infra notes $346-350$ and accompanying text.

277. See generally Dehousse \& Weiler, supra note 109, at 247 . 
If the Court of Justice were determined to play by the rules of subsidiarity in its own direct effects jurisprudence, would its case law be different than it has been up until now? Arguably, some of that case law would be due for rethinking, and some of it has in fact been rethought. In Procureur du Roi v. Dassonville, for example, the Court held that "[a]11 trading rules enacted by member-States which are capable of hindering, directly or indirectly, actually or potentially, intra-Community trade are to be considered as measures having an effect equivalent to quantitative restrictions." 278 Although it addresses the limits on intervention by the Court, rather than the Council or Commission, this principle poses an obvious threat to subsidiarity. The Court of Justice later modified its position in the Cassis de Dijon case, indicating a willingness to accept certain trade obstacles resulting from disparities among national marketing rules insofar as the latter are necessary in order to satisfy the "mandatory" requirements of Member States, ${ }^{279}$ and also respect the Court's own overriding principle of proportionality. From a subsidiarity point of view, this was a positive doctrinal development. It would certainly seem to be in keeping with subsidiarity and proportionality alike for the Court to ask itself more regularly whether the incremental gains in free movement that result from the Court's rejection of a particular Member State marketing rule are substantial enough to justify the Member State's loss of freedom to govern subjects that lie squarely within its sphere of competence.

Comparing the gains in economic integration with the loss of Member State autonomy is an inescapably difficult and once again deeply political operation, but it is also a good way for the Court of Justice to demonstrate its own belief that subsidiarity matters. The Court may find analogous ways to introduce such thinking into its case law regarding free movement of the various factors of production and the other directly effective provisions of the EC Treaty and the Community's secondary legislation. Some of the Court's more recent rulings suggest that it is indeed prepared to accept certain bona fide national marketing rules, despite their possibly disparate impact on non-nationals, when those rules seek to protect important non-economic interests of a local character and do not unreasonably burden interstate commerce in doing so. ${ }^{280}$

The Court has actually gone further than that to curb the erosion of Member State authority, in particular under Article 30. In its recent ruling in Criminal Proceedings against Keck and Mithouard, ${ }^{281}$ the Court cast

278. Case 8/74, Procureur du Roi v. Dassonville, 1974 E.C.R. 837, 852, [1974] 2 C.M.L.R. 436, 453-54.

279. See Case 120/78, Rewe-Zentral AG v. Bundesmonopolverwaltung für Branntwein (Cassis de Dijon), 1979 E.C.R. 649, [1979] 3 C.M.L.R. 494.

280. See, e.g., Case 302/86, Commission v. Denmark, 1988 E.C.R. 4607, [1989] 1 C.M.L.R. 619; Case 286/81, Criminal proceedings against Oosthoek's Uitgeversmaatschappij BV, 1982 E.C.R. 4575, [1983] 3 C.M.L.R. 428.

281. Cases C-267, 268/91, 1993 E.C.R. - (Nov. 24, 1993). 
into doubt the very premises of Cassis de Dijon; it held in general terms that

the application to products from other Member States of national provisions restricting or prohibiting certain selling arrangements is not such as to hinder directly or indirectly, actually or potentially, trade between Member States within the meaning of the Dassonville judgment provided that those provisions apply to all affected traders operating within the national territory and provided that they affect in the same manner, in law and in fact, the marketing of domestic products and of those from other Member States. ${ }^{282}$

According to the Court, when these conditions are met, the application of national law to the sale of products from another Member State "is not by nature such as to prevent their access to the market or to impede access any more than it impedes the access of domestic products" and "therefore fall [s] outside the scope of Article 30." 283 Whatever may have been the Court's purposes in retreating from well-established Article 30 case law, the Keck ruling demonstrates the Court's willingness to leave Member States the kind of regulatory scope that the principle of subsidiarity requires of the Community's political branches. ${ }^{284}$

My suggestion does not of course entail reopening the doctrines of direct applicability, direct effect, or supremacy. Nor does it require reexamining the Court's positions on enumeration, preemption, or implied powers, though doing so would not necessarily shake the legal foundations of the Community. My suggestion is two-fold: first, that the Court acknowledge more frankly than it has in the past that its judicial rulings (particularly on the direct effect of treaty and legislative norms) can have as erosive an effect on the right of Member State populations to govern matters of local concern as does the passage of unnecessary or unduly intrusive Community legislation; and, second, that the Court pay more attention in particular cases to whether the exercise of regulatory authority by a Member State or its subcommunities sufficiently impairs crossborder mobility to justify suppression of the relevant measure in the interest of the common market. Unless the Court of Justice gives evidence

282. Id. at I 16.

283. Id. I 17.

284. For a similar retreat by the Court of Justice, see the Court's recent preliminary ruling in Stoke-on-Trent City Council v. B \& Q PLC, 1992 E.C.R — (Dec. 16, 1992), [1993] I C.M.L.R. 426, holding, in apparent contradiction of its earlier ruling in Torfaen Borough Council v. B \& Q PLC, 1989 E.C.R. 3851, [1990] 1 C.M.L.R. 337, that "Article 30 . . does not apply to national legislation prohibiting retailers from opening their premises on Sundays." In Torfaen, the Court had made the exemption of Sunday trading laws from Article 30 conditional on a showing of proportionality, meaning that the "restrictive effects [of the laws] on Community trade... do not exceed the effects intrinsic to rules of that kind." Id. at 3889. Upon receipt of the Court's preliminary ruling in Stoke-on-Trent, the House of Lords immediately dismissed a company's appeal from a lower court injunction barring it from operating on Sunday. Stoke-on-Trent City Council v. B \& Q PLG, [1993] 2 C.M.L.R. 509 (H.L. 1993). 
that it takes both subsidiarity and proportionality seriously in its own conduct of business, it may not readily persuade the political institutions to do the same. It may thus have difficulty helping to quiet the political fears that fueled the impulse toward subsidiarity in the first place.

\section{Subsidiarity and U.S. Federalism}

Parts I and II of this Article explored the meaning and possible utility of subsidiarity in the European Community. They clearly sought to take subsidiarity seriously. In assessing the doctrine's potential for safeguarding the Community's federalist balance, the architects of Community reform might, however, have been expected to look, as they so often have, to the United States. ${ }^{285}$ They had done so on a variety of critical federalism issues-the interstate commerce clause, the enumeration of federal powers, implied powers, and the doctrine of preemption, to name only the most salient examples. It is reasonable to suppose, given subsidiarity's evident conceptual and operational difficulties, that those architects might also have inquired into the role, if any, that the notion of subsidiarity plays in the workings of U.S. federalism and into its efficacy in that setting. I conclude, however, that not only would the Europeans not have found subsidiarity in the lexicon of U.S. constitutional law, but they would not have found it to be a central feature of U.S. constitutional practice. In other words, the U.S. system offers few political or legal guarantees that the federal government will act only when persuaded that the states cannot or will not do so on their own.

U.S. experience accordingly lends little support to the claim that acknowledgment of a principle of subsidiarity is essential to sustaining the balance of power in a federal system. This in turn raises the question whether and on what basis the European Community architects can plausibly hope to make subsidiarity the Community's constitutional centerpiece, when a federal system that they so often consult for guidance on matters of federalism appears to give that notion so little recognition. I argue that the Community has good reason to rely on subsidiarity, not only despite the claim that the concept has been oversold in Europe, but also despite the claim that other federal systems (like the American) appear to do very nicely without it.

\section{A. Subsidiarity in the U.S. Institutional Context}

Subsidiarity is a term at least as alien to contemporary U.S. constitutional discourse as it was to the Europeans prior to the late-1980s. The United States is generally understood to exemplify a federal system of government: that is, a system in which political authority is constitutionally divided between a central government and the governments of the constituent states, and in which persons are concurrently subject to the authority of both governments, each acting within its own constitutional 
sphere. ${ }^{286}$ Thus, the term federalism suggests a state of affairs in which political authority is both in law and in fact allocated between two or more levels of government. However, although federalism conveys a general sense of a vertical distribution, or balance, of power, it is not generally understood as expressing a preference for any particular distribution of that power, much less dictating any particular inquiry into the implications of specific governmental action for that distribution. In this respect, federalism and subsidiarity, though of course closely related, are quite different.

To inquire into the role of subsidiarity in U.S. federalism is to ask whether the federal government's exercise of legislative or regulatory authority over a field lying within the constitutional limits of federal jurisdiction is limited in any significant way out of respect for the states' capacity to accomplish the federal government's general objectives within that field. ${ }^{287}$ The traditional response to this question has been that whether and to what extent federal legislative or regulatory authorities refrain from exercising powers that are properly theirs to exercise under our Constitution is a political question for the political branches to resolve. A powerful school of thought, associated with Herbert Wechsler, claims that restraints on intervention by the federal government flow chiefly from "the sheer existence of the states and [from] their political power to influence the action of the national authority."288

286. Daniel Elazar has written that

[a]s a political principle, federalism has to do with the constitutional diffusion of power so that the constituting elements in a federal arrangement share in the processes of common policy making and administration by right, while the activities of the common government are conducted in such a way as to maintain their respective integrities. Federal systems do this by constitutionally distributing power among general and constituent governing bodies in a manner designed to protect the existence and authority of all.

Elazar, supra note 25, at 5-6; see also Walter Hartwell Bennett, American Theories of Federalism (1964); Edward McWhinney, Comparative Federalism: States' Rights and National Power (2d ed. 1965).

287. The Office of Management and Budget (OMB), discussed extensively in later sections of this Article in connection with executive review of federal agency regulations, was essentially framing the subsidiarity idea when it reported that " [w] hether something could be regulated by the Federal government under the Constitution is a different matter than whether the Federal government should step in." OMB, Regulatory Program of the United States Government, 1988-1989, at 21 [hereinafter OMB, Regulatory Program, 1988-1989].

288. Herbert Wechsler, The Political Safeguards of Federalism: The Role of the States in the Composition and Selection of the National Government, 54 Colum. L. Rev. 543,544 (1954). Wechsler expressed confidence that U.S. political safeguards would allow Americans "to achieve a unity sufficient to resist their common perils and advance their common welfare, without undue sacrifice of their diversities and the creative energies to which diversity gives rise." Id. at 543.

Wechsler's theory in turn borrowed from the Federalist Papers, notably those of Madison. Madison wrote that "each of the principal branches of the federal government will owe its existence more or less to the favor of the State governments" and that Congress would be "disinclined to invade the rights of the individual States, or the prerogatives of 
Recent years, however, have witnessed growing concern over the impact of federal legislation and regulation on the fabric of U.S. federalism. Some commentators have taken to complaining of the "uncritical acceptance in many quarters of the notion that the federal government is the best level of government at which to establish regulatory programs." 289 These commentators have made the same kinds of claims that now seem to animate the advocates of subsidiarity in Europe, and they cite many of the virtues attributed to localism in that setting: the enhancement of liberty that accompanies the diffusion of power, the advantages of tailoring the law to local needs, the opportunity for heightened public participation, greater diversity, and enhanced political accountability. ${ }^{290}$ Occasionally commentators advance a regulatory philosophy that encapsulates

their governments." The Federalist No. 45, at 327, 332 (James Madison) (B. Wright ed., 1961).

289. C. Boyden Gray, Regulation and Federalism, 1 Yale J. on Reg. 93, 93 (1983); see also Daniel J. Elazar, American Federalism: A View from the States 255-56 (3d ed. 1984). See generally U.S. Advisory Comm'n on Intergovernmental Relations, Federal Regulation of State and Local Governments: The Mixed Record of the 1980s (1993) [hereinafter ACIR, Mixed Record]. The U.S. Advisory Commission on Intergovernmental Relations (ACIR) was created by Congress in 1959 as an independent, bipartisan commission to monitor the operation of the American federal system and to recommend improvements in the working relationships among federal, state, and local governments. Twenty of its 26 members are appointed by the President. (The 20 include three private citizens and three federal executive officials named directly by the President, as well as four governors, three state legislators, four mayors and three elected county officials named by the President from slates nominated by the National Governors' Association, the National Conference of State Legislatures, the National League of Cities, the U.S. Conference of Mayors, and the National Association of Counties.) The remaining six mernbers are three U.S. Senators chosen by the President of the Senate and three Representatives chosen by the Speaker of the House.

The ACIR recently issued the following statement:

The Commission finds that increasing federal regulation of state and local governments, the lack of adequate constitutional protection for state and local authority in the decisions of the federal courts, and the increasingly crowded policy agenda of the federal government have contributed to a serious and growing imbalance in the federal system.

Id. at 5; see also U.S. Advisory Comm'n on Intergovernmental Relations, Hearings on Constitutional Reform of Federalism: Statements by State and Local Government Association Representatives (1989) [hereinafter ACIR, Hearings]. The National Conference of State Legislatures has issued a formal statement on "the growing imbalance within the federal system," urging a number of strategies for reform, including strengthening fiscal impact assessment requirements, avoiding unfunded federal mandates, limiting grant conditions, and requiring express statutory statements of intent to preempt State law before Congress is assumed to have preempted State law or authorized agencies to do so. National Conference of State Legislatures, Official Policy on Federalism (on file with the Columbia Law Review).

290. See, e.g., Akhil Reed.Amar, Some New World Lessons for the Old World, $58 \mathrm{U}$. Chi. L. Rev. 483, 498 (1991); Michael W. McConnell, Federalism: Evaluating the Founders' Design, 54 U. Chi. L. Rev. 1484, 1493-1500 (1987); Deborah Jones Merritt, The Guarantee Clause and State Autonomy: Federalism for a Third Century, 88 Colum. L. Rev. 1, 3-10 (1988). On the Supreme Court, Justice $O^{\prime}$ Connor has been an ardent advocate of greater political autonomy for the states. See infra notes 340-346 and accompanying text. 
subsidiarity itself, advocating a presumption in favor of state or local regulation, rebuttable only by a showing that federal law is needed to avoid intolerable burdens on interstate commerce or to meet some other compelling national need. ${ }^{291}$ Other commentators, less committed to the deregulatory policies of the Reagan and Bush administrations, express the problem differently. Richard Pierce has framed the tension in terms highly resonant of the European debate: "[H] ow [are we] to allocate regulatory power in a way that will permit the nation to preserve both the values of a national market and [at the same time] the values of decentralized, government decisionmaking[?]"292

Unlike the European Community, where constitutional reform has been a conscious preoccupation for at least a decade, the institutional framework within which federalism is discussed in the United States today is not itself a subject of current debate. The written Constitution is not at present being reformed, nor are the basic institutions being reconstituted. Understandably, in such a setting commentators tend to eschew normative abstractions like subsidiarity, and instead ask themselves how precisely the existing institutions can modify their modes of operation to produce a more desirable federalism balance. ${ }^{293}$ In doing so, they may revisit and occasionally reassess the claims that are traditionally made in support of federalism, ${ }^{294}$ but they rarely advocate whole new federalism doctrines as such. This section accordingly looks for the theory or practice of subsidiarity within the framework or, to be more exact, within the interstices of existing U.S. institutions.

To discover whether subsidiarity, or a similar notion, plays a role in the conduct of U.S. federalism, one has in any event to transcend labels and look for equivalent thinking under any other name by which it might pass. $^{295}$ In this Part of the Article, I make that inquiry. I conclude first that, like its foreign-sounding name, subsidiarity is foreign to the law and practice of federal legislation. The working assumption in the United States seems in fact to be that Congress, by virtue of its composition and mode of operation, will not act with needless disregard for the states'

291. Gray, supra note 289 , cites as other possible grounds for rebuttal of the presumption: 1) the need for federal accommodation of competing state interests, 2) the need to avoid socially harmful competition between states, and 3) superior technical expertise at the federal level.

292. Richard J. Pierce, Jr., Regulation, Deregulation, Federalism, and Administrative Law: Agency Power to Preempt State Regulation, 46 U. Pitt. L. Rev. 607, 612 (1985); see also Alice M. Rivlin, Reviving the American Dream: The Economy, the States and the Federal Government 82-84 (1992).

293. See, e.g., Pierce, supra note 292, at 610-11.

294. See, e.g., Mark Tushnet, Federalism and the Traditions of American Political Theory, 19 Ga. L. Rev. 981 (1985).

295. Justice Antonin Scalia has concluded that to the extent that subsidiarity has any parallel in U.S. federalism, that parallel lies in the law governing federal preemption of state law. See Antonin Scalia, Subsidiarity à l'Américaine: C'est à Dire Preemption, in Maastricht, Subsidiarity and Italian-EC Relations 4, 4 (The Mentor Group, The Forum for U.S.-EC Legal-Economic Affairs, Venice, 1992). 
interest in regulatory autonomy. The courts accordingly have declined to enforce against Congress a specific legislative precept such as subsidiarity even though there is little evidence to suggest that Congress systematically follows any such precept of its own accord.

The situation is at least partially different when we turn to the exercise of authority by the federal agencies. On the one hand, just as Congress does not manifest a strong commitment to subsidiarity, it also has not exerted pressure on the agencies to act in ways that demonstrate a high degree of respect for the states' own capacity to govern. The courts likewise have shown substantial deference to the agencies' judgments that action within the outer limits of their statutory jurisdiction-often fully preemptive action-would be useful; the agencies do not have to demonstrate positively that the action is necessary or even that they think it is. The Executive, on the other hand, has attempted to introduce into the regulatory process certain considerations that bear directly on federalism and that at least in part reflect subsidiarity. Thus, a series of executive orders calls upon the federal agencies not only to minimize the regulatory burdens imposed on the private sector, but also to refrain from regulating at all if action at the state or local level would satisfactorily accomplish the federal government's objectives. These executive orders evoke, respectively, the Community law notions of proportionality and subsidiarity; their effectiveness with respect to subsidiarity in particular is, however, very doubtful.

\section{B. Congress and Subsidiarity}

The claim that the United States secures its federalism through the political process itself ordinarily brings the institution of Congress first to mind. This is the case in part because we tend to assign to Congress primary responsibility for allocating regulatory power between state and federal officials in areas of concurrent competence. ${ }^{296}$ However, it is also the case because Congress is composed of persons elected to office by state and local constituencies, that is, persons who may be thought unlikely to support federal legislation unless they genuinely believe that such legislation is necessary to achieve a purpose lying within the federal legislative sphere. Again, Herbert Wechsler forcefully argued that the fact that the national political authorities are selected by the people of the states, and function by reference to the political interests dominant in the states, naturally restrains their interventionist impulses. This is said to be the case particularly for Congress ${ }^{297}$ and even more particularly for

296. See Pierce, supra note 292, at 662-63. Pierce believes however that Congress needs substantial assistance from federal agencies in determining how to allocate state and federal powers in areas of shared competence. See id. at 663-65.

297. Wechsler argues: "To the extent that federalist values have real significance they must give rise to local sensitivity to central intervention; to the extent that such a local sensitivity exists, it cannot fail to find reflection in the Congress." Wechsler, supra note 288, at 547. (Wechsler considered it in fact "remarkable" that Congress functions as well as 
the Senate. ${ }^{298}$ The states' interest in preserving a healthy measure of autonomy in matters of shared federal and state competence is thereby assumed naturally to enter into and influence the federal legislative process in ways that guarantee due regard for the policy prerogatives of the states. ${ }^{299}$

Implicit in this analysis is the assumption that Congress actually determines, during the process of deliberating over proposed legislation, whether federal action is in fact needed for achieving its purposes. It is reasonable to assume that Congress routinely considers the "warrant" for federal action, in the general sense of satisfying itself that it has a constitutional basis for acting and that the action taken will serve a useful and legitimate purpose. Some scholars go further, however, maintaining as a description of political reality that proponents of federal legislation bear "the burden of persuasion" that action at the federal rather than the state

it does "given its intrinsic sensitivity to any insular opinion that is dominant in a substantial number of the states." Id.)

Compared to Congress, the President is much less subject to state and local political influences, if only because he or she represents the full national constituency. Wechsler nevertheless argues that numerous factors-including the states' then considerable degree of freedom to prescribe the methods for choosing electors of the President and VicePresident-make the Presidency more sensitive to state and local interests than we might ordinarily expect the federal chief executive to be. See id. at 552.

298. "[T]he Senate cannot fail to function as the guardian of state interests as such .... [Its composition] is intrinsically calculated to prevent intrusion from the center on subjects that dominant state interests wish preserved for state control." Id. at 548. Originally Senators were chosen by the state legislatures. The Seventeenth Amendment substituted direct popular election of Senators.

Even the House of Representatives, Wechsler argues, cannot escape the effects of state political influences. $\mathrm{He}$ cites in particular the extent of state control over voter qualifications and districting. See id. at 548-50.

299. Wechsler argues that the Supreme Court would find itself "on weakest ground when it opposes its interpretation of the Constitution to that of Congress in the interest of the states, whose representatives control the legislative process and, by hypothesis, have broadly acquiesced in sanctioning the challenged Act of Congress." Id. at 559.

For a recasting of Wechsler's arguments in terms of a theory of political accountability, see D. Bruce La Pierre, Political Accountability in the National Political Process-The Alternative to Judicial Review of Federalism Issues, 80 Nw. U. L. Rev. 577, 581-82 (1985).

Wechsler's theory, particularly the notion that the political safeguards of federalism are "inherent" in the structure of the federal government and thus automatically protective of the states, has been widely criticized. See, e.g., Carol F. Lee, The Political Safeguards of Federalism? Congressional Responses to Supreme Court Decisions on State and Local Liability, 20 Urb. Law. 301, 333 (1988); Lewis B. Kaden, Politics, Money and State Sovereignty, 79 Colum. L. Rev. 847, 897 (1979) ("The core of the federal conception is less an immutable structure ... than a political process); Andrzej Rapaczynski, From Sovereignty to Process: The Jurisprudence of Federalism after Garcia, 1985 Sup. Ct. Rev. 341,419 (1985) ("One of the positive effects of Garcia was to put to rest the old ideas of state sovereignty."). See also infra notes 339-340 and accompanying text. Lee argues that in order to ensure that Congress takes due account of the values of federalism, state and local governments "must make active efforts to protect their own interests" through lobbying and other activities, and that even then success is not assured. Lee, supra, at 335. 
level is required. ${ }^{300}$ The truth of this proposition has never to my knowledge been demonstrated. Congress' criteria for assessing the necessity for federal intervention do not in fact seem to be especially well-defined, and it is certainly far from clear that these criteria entail a prior assessment of the states' own ability, acting alone or in concert, to achieve the objectives that Congress has. ${ }^{301}$

Members of Congress, desiring political credit for the passage of legislation, may vigorously sponsor initiatives in Congress that could just as easily be undertaken at the state level; their task then is to produce a sufficient legislative coalition in support of their measures. Whether other members of Congress join that coalition depends in turn on factors that may have little to do with the interest of their states in self-governance as such. The interests of dominant social and economic groups within the states are probably a much more significant decisional factor. ${ }^{302}$ While the sponsor of federal legislation may well seek to persuade colleagues that the states in fact lack the capacity or will to solve a given problem, his or her primary task is to demonstrate that the problem ex-

300. See Wechsler, supra note 288, at 545 . Wechsler writes:

National action has thus always been regarded as exceptional in our polity, an intrusion to be justified by some necessity, the special rather than the ordinary case. . . . National power may be quite unquestioned in a given situation; those who would advocate its exercise must none the less answer the preliminary question why the matter should not be left to the states.

Id. at 544-45. He continues: "As a state legislature views the common law as something to be left alone unless a need for change has been established, so Congress has traditionally viewed the governance of matters by the states." Id. at 545; see also Gregory v. Ashcroft, 111 S. Ct. 2395, 2400 (1991) ("Congress may legislate in areas traditionally regulated by the States. This is an extraordinary power in a federalist system. It is a power that we must assume Congress does not exercise lightly.").

301. Committee reports favoring passage of federal legislation appear to differ widely in the extent to which they consider the efficacy of state law remedies. In rejecting a constitutional challenge to the Surface Mining Control and Reclamation Act of 1977, 30 U.S.C. $\$ 1201$ et seq. (1988), the Supreme Court noted that committees of both Houses of Congress had "explained that inadequacies in existing state laws and the need for uniform minimum nationwide standards made federal regulations imperative." Hodel v. Virginia Surface Mining \& Reclamation Ass'n, 452 U.S. 264, 280 (1981). On the other hand, the Court found determinative what appear to be only conclusory statements about the need for federal as opposed to state action in the legislative history of the Public Utility Regulatory Policies Act of 1978 (PURPA), whose constitutionality was likewise challenged on Commerce Clause and Tenth Amendment grounds.

Committees in both Houses of Congress noted the magnitude of the Nation's energy problems and the need to alleviate those problems by promoting energy conservation and more efficient use of energy resources. . . . Congress naturally concluded that the energy problem was nationwide in scope, and that these developments demonstrated the need to establish federal standards ....

Federal Energy Reg. Comm'n v. Mississippi, 456 U.S. 742, 756-57 (1982) (footnotes omitted).

302. See Lee, supra note 299, at 338-39; see also Zoë Baird, State Empowerment after Garcia, 18 Urb. Law. 491, 505-06 (1986). Baird suggests that "[t]he structural interests of the states ... are quite separate and distinct from the substantive policy interests of the people of the various states which are reflected in Congress." Id. at 504. 
ists and deserves to be addressed. Certainly Congress as an institution does not systematically evaluate the capacity or will of the states to deal with particular problems before seeking to address them at the federal level. ${ }^{303}$

Admittedly, an attachment to subsidiarity on the part of Congressabove and beyond the natural impulses to localism that have been ascribed to those who sit in the House and Senate-would be difficult to document even if it existed. Legislative power in Congress is heavily dispersed among committees and subcommittees of both houses. Favorable reporting of a bill from a subcommittee to a committee, and eventually to the full house, depends on a wide variety of political and personal considerations. It is simply not possible to generalize about the modes of reasoning or analysis that subcommittees and committees employ in policymaking. Moreover, debate in the full house is highly unstructured, and not tailored to ensure that any one consideration-least of all an abstraction like subsidiarity-is kept firmly in view.

Nevertheless, one can readily imagine ways in which the federal legislative process might be structured to promote consideration of federalism issues, and even subsidiarity, as a regular feature of that process. For example, the Rules of the House or Senate could require the committee report on a bill to assess the states' capacity to deal with the problem that the bill addresses and to demonstrate the need for federal intervention in their place. ${ }^{304}$ Alternately, a standing body within the House and Senate (or a body outside them but nevertheless within Congress) might be asked to review bills, at some point prior to a final vote, specifically from a

303. See generally Zimmerman, supra note 190 at 150-52. The National Governors' Association (NGA) has recommended that Congress make a specific determination of the compelling need for federal action before enacting legislation and that it actively involve the States before doing so. See NGA, Permanent Policy on Federalism, § 1.6.1 (1993). More specifically, the NGA has recommended the following with respect to federal preemption of State law:

There should be highly compelling reasons to justify federal actions that require changes in policies adopted by state and local officials, who are accountable to the same voters and whose performance is reviewed by them at least as often as the performance of Congress and the President.

In cases where Congress determines that federal preemption of state laws is in the national interest, the federal statute should accommodate state actions taken before its enactment. Provision[s] should be made to permit states that have developed stricter standards to continue to enforce them and to permit states that have developed substantially similar standards to continue to adhere to them without change.

Id. § 1.7.

304. The National Conference of State Legislatures has formally urged that "Members of Congress should expand formal and informal communications with their state legislatures in order to defend federal legislation that diminishes state powers and to explore less intrusive means of achieving national goals." National Conference of State Legislatures, supra note 289. 
subsidiarity point of view. ${ }^{305}$ The fact that such mechanisms do not exist is not itself surprising, given U.S. congressional traditions, but their absence is not without significance.

In the absence of any institutional mechanism of federalism review within Congress itself, advocates of greater state autonomy in political affairs strive to have their message heard by the committees and subcommittees that entertain specific bills considered to have significant federalism implications. ${ }^{306}$ They may testify at committee hearings or, failing that, submit written communications. Some lobbying groups have a standing commitment to localism; these include umbrella organizations like the National Conference of State Legislatures, ${ }^{307}$ the National Governors' Association, and the National League of Cities (to name a group

305. Cf. Zimmerman, supra note 190, at 152 (recommending subcommittee level preemption review and federalism assessment in each House of Congress, or, alternatively, establishment of a joint preemption-review committee). The state and Local Government Cost Estimate Act of 1981, 2 U.S.C. $§ 653$ 1988, requires the Congressional Budget Office (CBO) to prepare estimates (or "fiscal notes") of the anticipated costs imposed on state and local governments by all "significant" bills that have been reported favorably by a Senate or House committee to the whole Senate or House. See id. $\S 653$ (a) (2). The CBO is required to provide the estimate prior to floor consideration of the bill, and the estimate is ordinarily included in the committee's report. See id. $\$ 653(\mathrm{a})$. "Significant" bills are those likely to result in an annual cost to State and local governments of $\$ 200$ million or more, or "to have exceptional fiscal consequences for a geographic region or a particular level of government." Id. $\$ 653(\mathrm{c})$. The CBO's performance under the Act, which concerns itself only with direct implementation and compliance costs to state and local governments (and not with the intangible costs associated with their diminished political autonomy), has received mixed reviews. Cost estimates are described as often incomplete and too conservative, and performed "hurriedly on an ad hoc basis." See ACIR, Mixed Record, supra note 289, at 3. Between 1983 and 1988, the CBO performed 3554 cost estimates on 2821 bills. See id. at 62 . The ACIR now recommends that these fiscal impact analyses be conducted on bills before the stage of final committee action. See id. at 4 .

A large number of bills currently pending in the House or Senate would expand the CBO's cost-estimating responsibilities, or would impose cost estimate responsibilities on other bodies, such as the General Accounting Office or the Office of Management and Budget. See infra note 386. One such bill is the Fiscal Accountability and Intergovernmental Reform Act, H.R. 1295, 103d Cong., 1st Sess. (1993), introduced by Representative Moran.

306. On the lobbying techniques of state and local governments, see generally Elazar, supra note 289 , at 174-78. Lee notes that " [i]n conducting [its] business, Congress will consider the special needs and responsibilities of state and local governments only if they join the multitude of lobbying groups, use their institutional resources to promote their own interests, and-in short-play the congressional game with skill and sustained attention." Lee, supra note 299 , at 340 .

307. For a good example of testimony before Congress in opposition to federal legislation, organized by and on behalf of the National Conference of State Legislatures, see Product Liability Reform Act: Hearings on S. 1400 Before the Subcomm. on the Consumer of the Senate Comm. on Commerce, Science, and Transportation, 101st Cong., 2d Sess. 116 (1990) (statement of Michael Box, Alabama House of Representatives). Mr. Box testified against the enactment of federal products liability legislation (The Product Liability Reform Act, S. 1400), concluding that "[t] his is a matter that should and will be resolved in the state legislatures." Id. 
having a local rather than a state orientation), ${ }^{308}$ as well as individual state and local governments themselves. ${ }^{309}$ They may be joined in lobbying by other groups whose interest in pending legislation lies elsewhere but for which the federalism "card" may nevertheless be a useful argument.

One source of support that may be particularly relevant to mounting a political claim based on subsidiarity is state and local officialdom itself. For example, state highway officials, opposed to the conditioning of federal highway aid on a state's conformity to federal standards on the control of drunken driving, can provide key Senators and Representatives (perhaps most readily those of their own states) with material demonstrating the State Highway Department's successes in controlling drunken driving or their fresh and promising initiatives in that direction. The National Association of State Highway Officials may orchestrate the lobbying effort by disseminating information about proposed legislation, by pooling information about the records and initiatives of other states, by fashioning arguments, and by targeting those state highway officials who have particular access to a key member of Congress.310 Still, at the end of the day, those who would complain about the federalism implications of a bill enjoy no greater or different opportunities to influence its fate than those adversely affected by the bill's other aspects. It is sometimes suggested that Congress mandatorily consult the governors, state legislative leaders, or certain national organizations of state and local governments before enacting legislation having significant federalism implications. ${ }^{311}$ However, such proposals run up against the rather durable notion that the U.S. legislative process, in principle at least, has no privileged outside participants. ${ }^{312}$

308. The Council of State Governments is an organization that is devoted to the institutional interests of state governments but does not engage in legislative lobbying as such.

309. "Some state and local governments have proven themselves formidable lobbyists and indefatigable litigants." Merritt, supra note 290, at 5. The U.S. Advisory Commission on Intergovernmental Relations has recommended that state and local governments

identify those bills pending in the Congress ... that may have significant effects on state and local governments, ... press the committees and subcommittees of Congress responsible for the identified bills, early and often, to consider the effects on state and local governments, ... [and] provide ... the committees, subcommittees and the Congressional Budget Office with relevant fiscal and other information that should be taken into account . . . .

ACIR, Mixed Record, supra note 289 , at 4.

310. On the access of state administrative officials to members of Congress, see Elazar, supra note 289 , at $178-80$.

311. See Zimmerman, supra note 190 , at 158-59.

312. An innovative means recently developed by the states to heighten the accountability of Congress is the summoning of U.S. Senators and Representatives before joint sessions of their home state legislatures to explain their votes in Congress on controversial federal legislation, notably legislation imposing so-called "unfunded mandates" on the states. See infra note 386; see, e.g., Act No. 92-643 of the Alabama House of Representatives, House Joint Resolution Inviting the Alabama Delegation of the 
Whatever the mix of causes, state and local governments have taken to complaining loudly about the burdens and intrusiveness of federal legislation. Their specific grievances are taken up more closely in a later section of this Article dealing with the agencies rather than Congress. ${ }^{313}$ Suffice it to say that while the complaints that state and local governments direct to Congress pertain chiefly to the fiscal and administrative burdens of federal mandates (and the lack of federal fiscal support in meeting them), ${ }^{314}$ they also concern Congress' prescription of policy in areas of traditional state and local governance and, more generally, congressional erosion of state and local government authority. ${ }^{315}$

United States Congress to Address a Joint Session of the Legislature regarding Unfunded Federal Mandates. See generally William Claiborne, States Demand an Explanation: Federal Lawmakers Summoned to Justify Unfunded Mandates, Wash. Post, July 5, 1993, at A17.

313. See infra text accompanying notes $382-88$.

314. See ACIR, Regulatory Federalism: Policy, Process, Impact and Reform 180-86 (1984) [hereinafter ACIR, Regulatory Federalism] (citing in particular two National Governors' Association reports, Federal Roadblocks to Efficient State Government (1976) and Eliminating Roadblocks to Efficient State Government (1981)); see also ACIR, Mixed Record, supra note 289, at 55 ("[T] 1 he 1980s was a decade of continued legislative activity in regulatory federalism. This sustained level of regulatory activism appears all the more significant given the efforts devoted to regulatory relief during the decade and the overall reduction in legislative outputs.").

315. For a general discussion of the erosive effects of federal over-involvement in matters of traditional state and local concern, see Jon Felde, Civic Impairment: A Hidden Cost of Preemption and Mandates, Paper Delivered at the 1991 Annual Meeting of the American Political Science Association, Washington D.C. (Aug. 29-Sept. 1, 1991) (on file with the Columbia Law Review). See generally Rivlin, supra note 292, at 82-109.

The U.S. Advisory Commission on Intergovernmental Relations recently cited several pieces of legislation as "noted more for their intrusiveness than their expense." ACIR, Mixed Record, supra note 289, at 46. These include laws requiring states to allow longer and heavier trucks on interstate highways, to raise the minimum drinking age to 21 , and to abolish mandatory retirement age policies. See id. In an earlier publication, the ACIR described as "authority costs" those costs that undermine the political autonomy of state and local governments. See ACIR, Regulatory Federalism, supra note 314, at 312.

In August 1988 the National Governors' Association (NGA) adopted a detailed policy on federalism, one provision of which reads as follows:

1.3.4 Federal Forbearance. Not all problems require a uniform solution. Priorities and preferences may vary from state to state. The lack of universal action or uniform solutions does not in and of itself provide a sufficient rationale for federal action. Instead, we recommend that the development of future federal programs be guided first by four fundamental principles:

Federal action should be taken where constitutional authority for action is clear and certain.

Federal action should be limited to problems that are national in scope, problems where the national interest requires a universal or uniform solution, not merely problems that are common to all of the states.

Federal action should be sensitive to states' individual abilities to bring a unique blend of resources and approaches to common problems.

Unless the national interest is at risk, federal action should not preempt additional state action. 
This of course is not to say that Congress shows no respect for subsidiarity in its exercise of federal legislative power. Congress may show deference of this sort in a variety of ways. It may choose upon consideration not to legislate, or to legislate on certain aspects of a problem but not on others. When it does legislate, it may set standards that are general and possibly even vague, thus leaving states considerable interpretive freedom. Congress may in any event set standards that are minimal or expressly non-preemptive, thus explicitly allowing the states latitude to enact a higher level of protection. Whatever the degree of precision or strictness of the standards that it ultimately adopts, Congress can, and very often does, leave the states conditionally free to select the means they prefer to implement them. ${ }^{316}$

Though the term is of course never used, subsidiarity may also be built directly into the structure of federal legislation. Many statutes specifically allow the states to enact their own regulatory programs, provided they meet certain minimum federal criteria. The federal government may then intervene only if a state program fails by a certain date to meet those criteria or if a state has chosen not to enact any program at all. There are numerous variations on this theme, particularly in Congress' exercise of the power to regulate interstate commerce. The Clean Water Act, for example, calls upon the states to establish their own water quality standards, subject to EPA guidance and review in their drafting. ${ }^{317}$ If the EPA recommends changes in a state's standards, and the state fails to comply, the EPA may itself proceed to promulgate and implement water quality standards for the state. ${ }^{318}$ The Occupational Safety and Health Act entitles states to avoid the application of OSHA regulations on a given workplace health and safety issue by submitting a plan for adequately developing and enforcing state standards on that issue. ${ }^{319}$ The Resource Conservation and Recovery Act authorizes the EPA to issue permits allowing private parties to dispose of hazardous wastes, but allows a state at any time to supplant the federal program with a program of its own, provided it meets certain substantive and procedural requirements. ${ }^{320}$ The

Policy on Federalism of the National Governors' Association, reprinted in ACIR, Hearings, supra note 289 , at 42 . In 1993 , the NGA essentially reaffirmed these and related guidelines in the form of a "Permanent Policy."

316. For a catalogue of federal statutes that have deliberately extended regulatory relief to the states-in the form of exemptions, a relaxation of standards, increased flexibility in implementation, and the simplification of procedures. See ACIR, Mixed Record, supra note 289 , at $49-51$.

317. 33 U.S.C. § 1313(c) (1988).

318. See id.; Arkansas v. Oklahoma, 112 S. Ct. 1046, 1054-55 (1992).

319. See 29 U.S.C. $\$ 667$ (b) (1988). About half the states have received approval of their own state plans under this provision. See, e.g., Gade v. National Solid Wastes Management Ass'n, 112 S. Ct. 2374, 2382 (1992).

320. See 42 U.S.C. § 6926(b) (1988); United States Dep't of Energy v. Ohio, 112 S. Ct. 1627, 1631 (1992).

According to one authority, " $[\mathrm{p}]$ artial federal preemption has forced state legislatures to amend statutes to bring them into conformity with federal standards or lose 
examples could be multiplied. ${ }^{321}$

Federal enactments under the Spending Clause may also reflect a principle of subsidiarity. The Aid to Families with Dependent Children (AFDC) program, established by the Social Security Act of $1935,{ }^{322}$ illustrates this possibility. Under the statutory scheme, the federal government makes matching grants available to any state having an AFDC program conforming to federal requirements. Those requirements are far-reaching; for example, state programs must provide aid up to the age of eighteen for children who are deprived of parental support due to a parent's death, continued absence from the home, or physical or mental incapacity. ${ }^{323}$ Federal law also requires participating states to observe specific income-calculation rules, to afford aid applicants prescribed procedural rights, and to impose certain behavioral requirements on aid recipients. ${ }^{324}$ On the other hand, the states remain largely free in other important respects. They may not only prescribe additional procedural rules, but may actually set their own standards of need, grant-calculation procedures, and scales of aid..$^{325}$ The discretion thereby left to the states is considerable. ${ }^{326}$ In principle, a state may decline to establish a public assistance program meeting federal standards, or to establish any such program at all. The Social Security Act provides no federal sanctions in those circumstances, nor does it authorize the federal government to furnish public assistance directly in a state's place. Although, for obvious reasons, no state has deliberately foregone the opportunity to establish an AFDC program qualifying it for receipt of matching funds, ${ }^{327}$ federal law

responsibility for the partially preempted function and possibly federal grants-in-aid." Zimmerman, supra note 190 , at 8 .

321. See, e.g., the Alaska National Interest Lands Conservation Act, 16 U.S.C. §\$ 3101-3233 (1988). The Act declares that subsistence fishing and hunting shall be given priority over other types of fishing and hunting in rural parts of Alaska, and directs the Secretary of the Interior to implement this policy. Federal regulation, however, must be suspended if the State of Alaska enacts laws "which are consistent with, and which provide for the definition, preference, and participation specified in ... this title." Id. §3115(d). The Secretary of the Interior has statutory responsibility for monitoring the State's performance. See id. $\$ 3116$. For judicial interpretation of the statute, see Kenaitze Indian Tribe v. Alaska, 860 F.2d 312 (9th Cir. 1988), cert. denied, 491 U.S. 905 (1989).

322. 49 Stat. 627 (codified as amended at 42 U.S.C. $\S \S 601-606$ (1988)).

323. See 42 U.S.C. $\$ \S 606(a), 607$ (1988).

324. See id. $\S 602,606,612(1988)$.

325. See id. $\$ \S 602$ (a) (7), 603 (1988); King v. Smith, 392 U.S. 309, 318-19 (1968).

326. See U.S. Advisory Comm'n on Intergovernmental Relations, Statutory and Administrative Controls Associated with Federal Grants for Public Assistance 27-59 (1964) [hereinafter ACIR, Federal Grants]; Note, The Evolution of a Federal Family Law Policy Under Title IV-A of the Social Security Act: The Aid to Families with Dependent Children Program, 36 Cath. U. L. Rev. 197, 200 (1986).

327. See ACIR, Federal Grants, supra note 326 , at 6 .

The State of Wisconsin, however, recently announced its intention to withdraw entirely from the federal welfare program over the next five years and install its own state public assistance system. See Jason DeParle, Wisconsin Pledges to Take Own Path on Welfare by '99, N.Y. Times, Dec. 14, 1993, at A1. 
permits the states to do so. A legislative scheme of this sort evidences the principle of subsidiarity at work.

Due to their element of choice, legislative frameworks of the kind I have described are commonly said to exemplify "cooperative federalism." ${ }^{328}$ Because they prescribe federal standards, but leave to the states the power, consistent with those standards, to select the means for enforcing them and to conduct the enforcement, these frameworks sometimes are also described as exercises in "partial preemption." 329 Whatever the favored term, such formulas contain an ingredient of subsidiarity. Naturally, however, legislation of this kind reserves standard-setting powers to the states only within the specific limits that Congress sees fit to allow. This serves as an important reminder that subsidiarity ultimately depends as much on statutory content as on statutory structure.

A decision by Congress to refrain from legislating exhaustively on a given matter may of course be influenced by a variety of factors-technical, economic, and political in every sense of the word-and thus not be dictated by consideration of federal-state relations alone. It is therefore difficult, even when Congress demonstrates restraint-for example by curtailing the scope of legislation, by establishing vague or general statutory standards, by inviting more stringent state regulation, by leaving enforcement discretion to the states, or by giving them a "cooperative federalism" choice between federal and state regulation-to know its precise mix of reasons for doing so. Those who would assess the condition of federalism in the United States must thus reckon with the confusion of purposes that often animates Congress. The fact that it is difficult under these circumstances to demonstrate that Congress has acted out of solicitude for state and local autonomy-combined with the fact that Congress' perceived failures of solicitude tend by contrast to be apparentsuggests that only a more conspicuous inquiry by Congress into the need for federal legislation will reassure those who feel that the political balance has been fundamentally disturbed. The problem with treating federalism, under any formula, as a purely prudential consideration ${ }^{330}$ is that it fails to provide such reassurance.

\section{Constitutional Constraints}

The previous section suggests that while Congress has means of integrating federalism considerations like subsidiarity into the federal legislative process, it has only slightly developed them. The fact that Congress

328. Hodel v. Virginia Surface Mining \& Reclamation Ass'n, 452 U.S. 264, 289 (1981). On the term "cooperative federalism," see Zimmerman, supra note 190, at 147 ("The theory of cooperative federalism is . . . a relatively simple one, suggesting that each plane [of government] cooperate freely with the other to promote the common good.").

329. ACIR, Regulatory Federalism, supra note 314, at 34-37.

330. For an excellent argument in favor of treating the states' "autonomy of process" as a prudential principle of federalism, see $\mathrm{H}$. Jefferson Powell, The Oldest Question of Constitutional Law, 79 Va. L. Rev. 633 (1993). 
has left the legislative process unstructured does not, however, mean that the legislation resulting from the process is not itself subject to higher federalism principles, principles that the federal courts could conceivably enforce in challenges to the legislation's constitutionality. In this section, I trace the chief textual bases for permitting judicial review of Congress' decision to exercise the legislative power that it shares constitutionally with the states. In other words, I examine the claim that subsidiarity may be judicially enforceable against Congress. I conclude that the Supreme Court has denied itself a role in enforcing subsidiarity that one of these bases-the Commerce Clause-arguably invites it to play, while giving the other of these bases-the Tenth Amendment-a succession of meanings that avoid precisely the federalism question that subsidiarity raises.

One possible avenue for constitutionally curtailing Congress' exercise of power under the Interstate Commerce Clause-in the interest of subsidiarity or, more generally, of federalism-is through narrow construction of that Clause itself. However, this avenue has long since been closed. Almost as if in direct denial of the claim that the exercise of the Commerce Power is subject to a judicially enforceable principle of subsidiarity, the Supreme Court 170 years ago wrote that the power is "complete in itself, may be exercised to its utmost extent, and acknowledges no limitations, other than are prescribed in the Constitution." 331 The Court has maintained this view fairly consistently ever since. ${ }^{332}$

The task of a court that is asked to determine whether a particular exercise of congressional power is valid under the Commerce Clause is relatively narrow. The court must defer to a congressional finding that a regulated activity affects interstate commerce, if there is any rational basis for such a finding. This established, the only remaining question for judicial inquiry is

331. Gibbons v. Ogden, 22 U.S. (9 Wheat.) 1, 196 (1824).

332. Although there is broad support today for an expansive reading of the federal Commerce Clause power, there was no such understanding in the early New Deal era. See, e.g., Hammer v. Dagenhart, 247 U.S. 251 (1918) (holding manufacture does not fall under the Commerce Clause as production of goods is not commerce); see also Carter v. Carter Coal Co., 298 U.S. 238 (1936) (holding unconstitutional federal regulation of coal production as the "tax" imposed by the federal government is actually a penalty and thus a misuse of its taxing power); United States v. E.C. Knight Co., 156 U.S. 1 (1895) (holding unconstitutional US attempt to prevent a sugar monopoly by thwarting an intrastate contract of one large sugar manufacturer as the contract was totally under state law).

Federal courts, by way of exception, have occasionally held that Congress exceeds its powers under the Commerce Clause by making conduct a federal crime without asserting any rational nexus between that conduct and interstate commerce. See, e.g., United States v. Lopez, No. 92-5641, 62 U.S. L.W. 2173 (5th Gir. Sept. 15, 1993) (1990 Gun-Free School Zones Act unconstitutional in absence of interstate commerce nexus to ban on firearms in school zones, where interstate commerce is not made an element of the offense and Congress fails to find an effect on interstate commerce); United States v. Cortner, No. 3-9300009, 62 U.S. L.W. 1067 (M.D. Tenn. Oct. 19, 1993) (federal hijacking statute unconstitutional because it fails to assert any nexus between the criminal act and interstate commerce, especially as applied to a purely intrastate car theft). 
whether "the means chosen by [Congress is] reasonably adapted to the end permitted by the Constitution. ... .

Judicial review in this area is influenced above all by the fact that the Commerce Clause is a grant of plenary authority to Congress. ${ }^{333}$

The Tenth Amendment furnishes a second constitutional basis on which the federal courts could conceivably police congressional interference with state sovereignty through legislation enacted under the Commerce Clause. In 1976, the Supreme Court in fact ruled in National League of Cities $v$. Usery, ${ }^{334}$ that federal legislative power under the Commerce Clause does not extend so far as to displace the states' authority to structure employment relations in areas of "traditional governmental functions." 335 But the cases that followed National League of Cities suggested that the area sheltered from federal governance by the Tenth Amendment was ultimately a narrow one, limited to matters inextricably linked to the concept of state sovereignty itself. ${ }^{336}$ If the Tenth Amendment limited Congress' use of the commerce power only when Congress sought to regulate a state in its capacity as a sovereign, ${ }^{337}$ then on most matters-especially the regulation of private activity-it would still leave Congress complete freedom of choice in allocating regulatory responsibilities between federal and state authorities.

333. Hodel v. Virginia Surface Mining \& Reclamation Ass'n, 452 U.S. 264, 276 (1981) (quoting Heart of Atlanta Motel, Inc. v. United States, 379 U.S. 241, 262 (1964), and citing N.L.R.B. v. Jones \& Laughlin Steel, 313 U.S. 416 (1947) and Wickard v. Filburn, 317 U.S. 111 (1942), and United States v. Darby, 312 U.S. 100 (1941)). The Court in Hodel rejected the argument that existing legislation rendered unnecessary Congress' use of the Commerce Power to enact new legislation:

Appellees' essential challenge to the means selected by the Act is that they are redundant or unnecessary .... The short answer to this argument is that the effectiveness of existing laws in dealing with a problem identified by Congress is ordinarily a matter committed to legislative judgment.

Id. at 283. Justice Powell's concurring opinion in the Hodel case is especially revealing: The Surface Mining Act mandates an extraordinarily intrusive program of federal regulation and control of land use and land reclamation, activities normally left to state and local governments. But the decisions of this Court over many years make clear that, under the Commerce Clause, Congress has the power to enact this legislation.

Id. at 305 (Powell, J., dissenting).

334. 426 U.S. 833 (1976), overruled by Garcia v. San Antonio Metro. Transit Auth., 469 U.S. 528 (1985).

335. Id. at 852.

336. See, e.g., Federal Energy Reg. Comm'n v. Mississippi, 456 U.S. 742 (1982); Hodel, 452 U.S. 264. The Court in Hodel identified four conditions as necessary under National League of Cities for state and local government immunity from federal regulation pursuant to the Commerce Clause: (1) the federal law must regulate the states as states; (2) it must address matters that indisputably engage state sovereignty; (3) state compliance must directly impair the states' ability to organize themselves to carry out traditional governmental functions; and (4) the federal government must lack a sufficient interest in the matter to justify state submission. See id. at 287-88.

337. See Pierce, supra note 292 , at $642-43$. 
Congress found its legislative freedom reinforced when National League of Cities, which had been decided by a 5-4 majority, was overruled by the same margin nine years later in Garcia v. San Antonio Metropolitan Transit Authority. ${ }^{338}$ There, the Court rejected the category of "traditional governmental functions" as an unworkable one. While affirming that the states in the U.S. constitutional system possess a core of sovereignty, the Court held that that core is guaranteed not by a set of independently prescribed and judicially enforceable limits on the exercise of federal legislative power, but instead by the structure and functioning of the federal government itself, and notably by the role of the states in the federal system. ${ }^{339}$ Under Garcia, Congress enjoys virtually unreviewable discretion to allocate responsibilities in areas of concurrent state and federal competence. ${ }^{340}$

338. 469 U.S. 528 (1985); see also South Carolina v. Baker, 485 U.S. 505 (1988).

339. The Court stated:

[T] he Framers chose to rely on a federal system in which special restraints on federal power over the States inhered principally in the workings of the National Government itself, rather than in discrete limitations on the objects of federal authority. State sovereign interests, then, are more properly protected by procedural safeguards inherent in the structure of the federal system than by judicially created limitations on federal power.

Garcia, 469 U.S. at 552.

In response to Garcia, and on the recommendation of the Council on State Government's (CSG) Intergovernmental Affairs Committee, the Executive Committee of the CSG adopted a resolution in favor of adding the following language to the Tenth Amendment: "Whether a power is one reserved to the states or to the people, shall be a matter to be decided by the Courts." Intergovernmental Affairs Committee of the Council of State Governments' Resolution to the Court of State Governments, Executive Committee on Restoring Balance in the Federal System (Sept. 23, 1989) (on file with Columbia Law Review).

340. The majority in Garcia "doubt[ed] that courts ultimately can identify principled constitutional limitations on the scope of Congress' Commerce Clause powers over the States merely by relying on a priori definitions of state sovereignty." Garcia, 469 U.S. at 548.

Justice Powell wrote a vigorous dissent, accusing the majority of taking an unrealistically positive view of the political process and its capacity to sustain the values of federalism. He cited specifically the progressive weakening of local political parties, the growth in importance of national media, and the power of permanent congressional staff in developing and drafting federal law. See id. at 565 n.9, 576 (Powell, J., dissenting).

However, it is Justice O'Connor's dissent in Garcia that is most sympathetic to the idea of enforcing subsidiarity through the Tenth Amendment:

The true "essence" of federalism is that the States as States have legitimate interests which the National Government is bound to respect even though its laws are supreme....

... Just as surely as the Framers envisioned a National Government capable of solving national problems, they also envisioned a republic whose vitality was assured by the diffusion of power not only among the branches of the Federal Government, but also between the Federal Government and the States . . . . 
Though recent Supreme Court opinions suggest that Garcia's insulation of federal statutes from Tenth Amendment scrutiny is no longer airtight, they still do not allow a great deal of scope for subsidiarity as an instrument of constitutional review. In Gregory v. Ashcroft, ${ }^{341}$ Justice O'Connor, speaking for a majority of the Court, found in the Tenth Amendment a rule of statutory interpretation (a "plain statement rule") according to which the courts should not lightly assume that Congress intends to override the states' "substantial sovereign powers under our constitutional scheme." 342 Like any canon of construction, however, the rule concedes Congress' right to indicate otherwise. Moreover, that case, like both National League of Cities and Garcia, dealt only with the application of general federal legislation to the functioning of state and local government itself, and more particularly to the legal conditions of government employment. ${ }^{343}$

Justice O'Connor's majority opinion in the still later case of New York v. United States ${ }^{344}$ has potentially more far-reaching Tenth Amendment consequences. It appears to reopen the door to the direct constitutional challenge of federal legislation on Tenth Amendment grounds. ${ }^{345}$ More-

... The Framers' comments indicate that the sphere of state activity was to be a significant one .... The States were to retain authority over those local concerns of greatest relevance and importance to the people.

Id. at 581-82 (O'Connor, J., dissenting).

341. 111 S. Ct. 2395 (1991).

342. Id. at 2401. Justice O'Connor writes:

[I]nasmuch as this Court in Garcia has left primarily to the political process the protection of the States against intrusive exercises of Congress' Commerce Clause powers, we must be absolutely certain that Congress intended such an exercise.

Id. at 2403.

343. Ashcroft involved the application of the Federal Age Discrimination in Employment Act of 1967, Pub. L. No. 90-202, 81 Stat. 608 (codified as amended at 29 U.S.C. $\$ \S 621-634$ (1988)), to appointed state judges. Justice O'Connor's opinion nevertheless contains a general encomium to federalism:

This federalist structure of joint sovereigns preserves to the people numerous advantages. It assures a decentralized government that will be more sensitive to the diverse needs of a heterogeneous society; it increases opportunity for citizen involvement in democratic process; it allows for more innovation and experimentation in government; and it makes government more responsive by putting the States in competition for a mobile citizenry.

Perhaps the principal benefit of the federalist system is a check on abuses of government power. . . Just as the separation and independence of the coordinate Branches of the Federal Government serves to prevent the accumulation of excessive power in any one Branch, a healthy balance of power between the States and the Federal Government will reduce the risk of tyranny and abuse from either front.

Ashcroft, 111 S. Ct. at 2399-40 (citations omitted).

344. 112 S. Ct. 2408 (1992).

345. See id. at 2428-29. In New York v. United States, the Court invalidated a provision of the Low-Level Radioactive Waste Policy Amendments Act of 1985, §5(d) (2) (C), Pub. L. No. 99-240, 99 Stat. 1842 (codified at 42 U.S.C. $\$ 2021$ (d)(2)(C) (1988)), because it required the states, as a matter of federal law, to choose between either accepting 
over, rather than merely protecting states and localities from federal regulation of their operations (as National League of Cities had sought to do), the Court announced a rule forbidding Congress, as a general matter, to compel the states to enact and enforce federal regulatory programs. A rule protecting the states from having to govern according to Congress' instructions was described as necessary to ensure that the allocation of a community's resources is made by persons who are politically accountable to that community, and that the states do not come to be treated as "mere political subdivisions of the United States." ultimately condemned only what it called federal "commandeer[ing]" of a state regulatory apparatus, that is to say, laws requiring that states spend their administrative resources on implementing policies dictated by the federal government. ${ }^{347}$

The decision in New York $v$. United States may thus impose new and important Tenth Amendment limits on Congress' exercise of federal legislative power. ${ }^{348}$ The support that the Court has thereby lent to federalism is not without consequences for subsidiarity. If Congress may not enact regulatory programs, or delegate the power to enact them to the federal agencies, unless it is prepared to bear the full cost of implementing those programs in the event the states ultimately choose not to participate, the net effect may well be less federal intervention even where it would otherwise be constitutionally permissible. Subsidiarity would to that extent be indirectly advanced. That possibility notwithstanding, the Court in New York v. United States nevertheless broadly conceded Congress' power under the Commerce Clause "to offer States the choice of

ownership of radioactive waste generated within their borders or regulate pursuant to federal standards. See $112 \mathrm{~S}$. Ct. at 2428-29.

The Court's rationale for reopening the door to Tenth Amendment challenges was that entertaining them is no different than determining whether Congress acted within the scope of its enumerated powers: "Whether one views [the provision invalidated] as lying outside Congress' enumerated powers, or as infringing upon the core of state sovereignty reserved by the Tenth Amendment, the provision is inconsistent with the federal structure of our Government established by the Constitution." Id. at 2429.

Justice White, in a partial dissent, criticized the majority for not following the Garcia case. See id. at 2443 (White, J., dissenting).

346. Id. at 2434. For an able critique of Justice O'Connor's claim to historical support for an "autonomy of process" principle in favor of the States, which nonetheless praises the principle as a prudential doctrine, see Powell, supra note 330 . For the claim that Justice O'Connor is correct as to the federal government's commandeering of state legislatures, but not of state administrative agencies (and courts), see Saikrishna Prakash, Field Office Federalism, 79 Va. L. Rev. 1957 (1993). See also Richard E. Levy, New York $v$. United States: An Essay on the Uses and Misuses of Precedent, History and Policy in Determining the Scope of Federal Power, 41 Kan. L. Rev. 493 (1993); Ann Althouse, Variations on a Theory of Normative Federalism; A Supreme Court Dialogue, 42 Duke L.J. 979 (1993); H. Jefferson Powell, The Oldest Question of Constitutional Law, 79 Va. L. Rev. 633 (1993).

347. $112 \mathrm{~S}$. Ct. at 2420. For a subsequent application of the rule stated in New York $v$. United States, see Board of Natural Resources v. Brown, 992 F.2d 937 (9th Cir. 1993).

348. See supra note 346 . 
regulating [an] activity according to federal standards or having state law pre-empted by federal regulation." 349 The Court went on to say that

No matter how powerful the federal interest involved, the Constitution simply does not give Congress the authority to require the States to regulate. The Constitution instead gives Congress the authority to regulate matters directly and to pre-empt contrary state regulation. Where a federal interest is sufficiently strong to cause Congress to legislate, it must do so directly; it may not conscript state governments as its agents. ${ }^{350}$

The Constitution permits both the Federal Government and the States to enact legislation regarding the disposal of low level radioactive waste. The Constitution enables the Federal Government to pre-empt state regulation contrary to federal interests, and it permits the Federal Government to hold out incentives to the States as a means of encouraging them to adopt suggested regulatory schemes. It does not, however, authorize Congress simply to direct the States to provide for the disposal of the radioactive waste generated within their borders. ${ }^{351}$

Federalism and Tenth Amendment debates in the Supreme Court may be far from over. But even those Justices most receptive to a Tenth Amendment review of federal legislation seem to acknowledge that it is not Congress' decision to regulate interstate commerce, but only its coercion of the states in the enforcement of federal law, that poses a problem under that Amendment.

In sum, neither National League of Cities (prior to its overruling by Garcia) nor New York $v$. United States is directly responsive to subsidiarity as the Europeans conceive of it. Subsidiarity is not served by carving out a privileged zone of "traditional governmental functions," as under $\mathrm{Na}$ tional League of Cities, and sheltering it from federal governance; subsidiarity calls for the practice of legislative self-restraint across the full range of substantive lawmaking power. Nor is subsidiarity secured by the New York v. United States remedy of "offer[ing] States the choice of regulating [an] activity according to federal standards or having state law preempted by federal regulation. ${ }^{352}$ It seeks to preserve the states' authority to prescribe rules of law and not merely to decide whether to lend their resources to the administration of federal law.

349. 112 S. Ct. at 2424.

350 . Id. at 2429.

351. Id. at 2435. Justice White, in a partial dissent, underscored Congress' full liberty, even under the majority opinion, to regulate the disposal of radioactive waste directly under the Commerce Clause:

Congress has the power pursuant to the Commerce Clause to regulate directly the producers of the waste. Thus, as I read it, Congress could amend the statute to say that if a State fails to meet the [deadline for adequate waste disposal] ... no low-level radioactive waste may be shipped out of the State. . . .

Id. at 2445 (White, J., dissenting).

352. Id. at 2424. 
The language of the Tenth Amendment contributes to its awkwardness as an anchor for subsidiarity. The Amendment provides that " $[t]$ he powers not delegated to the United States by the Constitution, nor prohibited by it to the States, are reserved to the States respectively, or to the people." ${ }^{353}$ Language that limits the federal government to the powers conferred upon it by the Constitution, leaving all others to be exercised by the states, basically expresses a principle of enumeration of powers. ${ }^{354}$ It is quite difficult to see how a principle of enumeration of federal powers can even begin to address the political allocation of power where power is constitutionally shared. Yet that is precisely subsidiarity's province.

We thus find that, although federalism lies at the heart of the United States constitutional system, neither the text of the Constitution nor the Court's federalism jurisprudence offers very strong legal guarantees that a proper political balance between the federal government and the states will be maintained. ${ }^{355}$ The Tenth Amendment, whose breadth lends it only a superficial resemblance to the principle of subsidiarity, simply cannot be read as subsidiarity's U.S. counterpart. The Supreme Court's position in Garcia-namely, that the legislative process itself may and must be relied upon to safeguard the basic autonomy of the states-remains essentially intact. Even the prohibition on commandeering announced by the Court in New York $v$. United States, while giving new life to the Tenth Amendment as a constitutional instrument, targets only a very specific form of federal imposition on the states. If the courts mean to enforce a principle of power-sharing having a scope of application as broad as subsidiarity, they must do so on essentially nonconstitutional grounds.

\section{Subsidiarity and the Judicial Function}

I have thus far argued that subsidiarity, as understood by the Europeans, is not a judicially enforceable constitutional norm in the United States, but rather a value whose fortunes are essentially left to the political forces. However, even without the benefit of a constitutional

353. U.S. Const. amend. X.

354. The Supreme Court has described the Tenth Amendment as "a tautology." New York v. United States, 112 S. Ct. at 2418 (citing United States v. Darby, 312 U.S. 100, 124 (1941) (The Tenth Amendment "states but a truism that all is retained which has not been surrendered.")).

355. Although the Constitution's Guarantee Clause has come into consideration recently as a source of federalism constraints on Congress, the Clause has been thought to protect at most the states' autonomy in defining the franchise for state office, organizing the machinery of state government, establishing state personnel policies, and allocating state regulatory and enforcement resources, but not to protect states from federal laws governing private conduct in areas traditionally regulated by the states. See Merritt, supra note 290 , at 70 (" $[T]$ he protection afforded states by the guarantee clause does not prevent Congress from preempting areas of substantive state law. The guarantee clause grants states a measure of autonomy over their governmental processes; it does not promise them sovereignty over any aspect of private behavior."). 
doctrine bearing its name, the federal courts could move Congress in the direction of subsidiarity. They could do so most directly by enforcing statutory language that is itself suggestive of subsidiarity. Perhaps even more effectively, they could interpret the doctrine of federal preemption and the doctrine of frustration of congressional purpose to advance the goals of subsidiarity indirectly.

1. Subsidiarity as an Enforceable Legislative Norm. - The federal courts may readily enforce subsidiarity once Congress enacts legislation either explicitly or implicitly endorsing it. In principle, the courts should be as prepared to give effect to subsidiarity as to any other value that Congress effectively incorporates into federal legislation. Acting in this mode, their commitment to subsidiarity would be largely derivative of Congress', but would be important nonetheless. We have seen, for example, that Congress sometimes safeguards the states' rights to establish standards governing private conduct within their borders, while reserving the federal government's right to displace them with national standards if they fail to meet statutorily prescribed criteria. ${ }^{356}$ Such forms of "cooperative federalism" are precisely the kinds of subsidiarity-inspired statutory arrangements that the courts, in appropriate cases, can and will enforce in favor of the states, without further resort to the subsidiarity principle itself. ${ }^{357}$ Yet even under these schemes, the courts ultimately can protect the policymaking freedom of the states only to the extent that federal statutory and regulatory standards allow.

2. Premption and Frustration of Congressional Purpose. - Federal preemption is one way in which Congress shows its preference for federal over state regulation of a given matter. When Congress preempts a matter totally-in the sense of occupying the field-it forecloses state regulation of it altogether. If Congress always acted in keeping with subsidiarity, it would preempt state law, and certainly preempt it totally, only when convinced that the states lack the capacity to regulate the field effectively. It is of course difficult to know just how closely Congress explores the state-level options before deciding to preempt. For its part, the Supreme Court has consistently held that "the question whether a certain state action is preempted by federal law is one of congressional intent"; ${ }^{358}$ "The purpose of Congress is the ultimate touchstone." 359 Thus, Congress itself determines whether and to what extent the states have a continuing governance role in fields of concurrent jurisdiction, and the courts ap-

356. See supra notes $317-329$ and accompanying text.

357. See, e.g., Kenaitze Indian Tribe v. Alaska, 860 F.2d 312 (9th Cir. 1988), cert. denied, 491 U.S. 905 (1989) (holding that where a state exercises its power to regulate pursuant to a federal statute, the state must use such power in a manner that is consistent with congressional intent).

358. Gade v. National Solid Wastes Management Ass'n, 112 S. Ct. 2374, 2381 (1992) (quoting Allis-Chalmers Corp. v. Lueck, 471 U.S. 202, 208 (1985)); Ingersoll-Rand Co. v. McClendon, 498 U.S. 133, 137-38 (1990) (also quoting Allis-Chalmers Corp. v. Lueck).

359. Allis-Chalmers Corp. v. Lueck, 471 U.S. at 208 (quoting Malone v. White Motor Corp., 435 U.S. 497, 504 (1978)). 
proach this determination basically as a matter of statutory interpretation. ${ }^{360}$ This is neither surprising nor at all inconsistent with the earlier discussion of the Commerce Clause and the Tenth Amendment. ${ }^{361}$

It is when Congress fails to deal explicitly with the preemption question that the courts regain the opportunity to shape the federal-state balance and, more specifically, to advance the purposes of subsidiarity. The Court has described the judicial task in such situations as one of analyzing the general objectives and structure of the federal legislation and determining whether they fairly accommodate a continuing regulatory role for the states. ${ }^{362}$ Though each case turns on its own facts, the cases as a whole suggest that Congress is not deemed to have occupied the field unless it has so pervasively regulated it, or has such a predominant interest in it, as to imply the exclusion of any further action by the states. ${ }^{363} \mathrm{In}$ other words, while ultimately a matter of congressional intent, preemption of a field is not to be lightly inferred. ${ }^{364}$ Since a presumption against preemption preserves the states' rights to regulate a matter within their legislative sphere, it points in the same general direction as subsidiarity. On the other hand, the presumption being a relatively mild one, the support that it gives subsidiarity is correspondingly mild. ${ }^{365}$

360. See, e.g., Pierce, supra note 292, at 629-31, citing Jones v. Rath Packing Co., 430 U.S. 519 (1977); Northern Natural Gas Co. v. State Corp. Comm'n, 372 U.S. 84 (1963); Rice v. Santa Fe Elevator Corp., 331 U.S. 218, 230 (1947); see also William Cohen, Congressional Power to Define State Power to Regulate Commerce: Consent and Preemption, in 2 Courts and Free Markets 523, 525 (Terrance Sandalow \& Eric Stein eds., 1982) (arguing that Congress may occupy the field, even to the extent of regulating matters of peculiarly local concern that nevertheless affect interstate commerce. "[T] he issue, in preemption cases, simply stated, is not what Congress has the power to do, but what Congress has done." Id. at 537).

361. See supra notes $331-340$ and accompanying text.

362. "[Since] Congress rarely addresses issues of preemption of state law explicitly or in detail . . . the Court usually must determine congressional intent based on its analysis of the general purposes of the federal statute and the relationship between those general purposes and the state action at issue." Pierce, supra note 292, at 629; see, e.g., Pilot Life Ins. Co. v. Dedeaux, 481 U.S. 41, 51 (1987).

363. See, e.g., Hillsborough County, Fla. v. Automated Medical Labs., 471 U.S. 707, 713 (1985); see also id. at 715 (public health and safety is not a field in which a dominant federal interest will lightly be assumed).

364. See Wisconsin Pub. Intervenor v. Mortier, 111 S. Ct. 2476, 2481-82 (1991); Sunstein, supra note 22 , at $164,225-26$.

365. See generally Scalia, supra note 295 , at 4 .

Legislation has been introduced in the Senate that would markedly strengthen the presumption against preemption. The legislation- "The Preemption Clarification and Information Act" - would provide that "[n]o statute, or rule promulgated under such statute, shall preempt, in whole or in part, any state or local government law, ordinance, or regulation, unless the statute explicitly states that such preemption is intended or unless there is a direct conflict between such statute and state or local law, ordinance, or regulation, so the two cannot be reconciled or consistently stand together." S. 480, 103d Cong., 1st Sess. (1993), introduced by Senators Levin and Durenberger; see also H.R. 2327, 103d Cong., 1st Sess. (1993). 
Even if state measures are not altogether preempted (because Congress is not found to have occupied the field), a particular state measure may nevertheless so significantly frustrate the policies underlying federal law as to render it incompatible with federal law and thus invalid under the Supremacy Clause. A state measure will accordingly be invalidated if it is found to have a significant negative impact on the full achievement of congressional purposes. ${ }^{366}$ Determining whether a particular state measure, although not in direct conflict with federal law, nevertheless frustrates congressional purposes to such an extent has been termed a basically political call, a call that Congress itself for one reason or another may have failed to make. ${ }^{367}$

Due to the ad hoc nature of these decisions, and the political character of the criteria on which they turn, it is difficult to tell as a general matter how much political latitude they leave to the states. One general conclusion that has been drawn from the cases, however, is that state law measures in areas of state jurisdiction are commonly allowed to stand even though the federal government is already involved in regulating the field and the state measure conflicts with the goals of the federal regulation. ${ }^{368}$ Like a mild presumption against preemption, a mild reluctance to conclude that state law impermissibly frustrates achievement of congressional purposes enlarges, but only moderately, the states' freedom to make policy within their constitutional sphere. ${ }^{369}$

The relationship between preemption and frustration of congressional purpose, on the one hand, and subsidiarity, on the other, is however a very imperfect one. Judicial policies on preemption and frustration of congressional purpose determine how much policymaking freedom the states enjoy in governing a matter only after Congress has acted in relation to it; they do not determine the federal government's

366. See, e.g., Pierce, supra note 292, at 630 (citing Ray v. Atlantic Richfield Co., 435 U.S. 151 (1978)); see also Hines v. Davidowitz, 312 U.S. 52, 67 (1941).

367. See Cohen, supra note 360 , at 541; Roger C. Cramton, Pennsyluania v. Nelson: A Case Study in Federal Preemption, 26 U. Chi. L. Rev. 85, 87-88 (1958). According to Cohen, the outcome seldom turns on the "technical mesh" between state and federal law or the consequences of "overlap," but rather on the wisdom of the respective rules, the desirability (in light of the interests affected) of having the matter regulated at the one level or the other, and the relative advantages of having a uniform federal rule (or at least a rule fixed by an authority having a national perspective) or one that varies locally. See Cohen, supra note 360 . These are precisely the kinds of factors that Congress would in principle consult if it were facing the question.

368. See, e.g., Pierce, supra note 292, at 631-36 (citing Silkwood v. Kerr-McGee Corp., 464 U.S. 238 (1984); Arkansas Elec. Power Coop. Corp. v. Arkansas Pub. Serv. Comm'n, 461 U.S. 375 (1983); Pacific Gas \& Elec. Co. v. State Energy Resources Conservation \& Dev. Comm'n, 461 U.S. 190 (1983)).

369. For a legislative proposal in Congress that would allow federal preemption of state law on the basis of inconsistency between the two only when "there is a direct conflict between [them], so the two cannot be reconciled or consistently stand together," see The Preemption Clarification and Information Act, S. 480, supra note 365; H.R. 2327, supra note 365 . 
initial warrant to act. Subsidiarity operates very differently. It determines whether the states should be left free to regulate a matter in the first place, and it is the states' capacity to achieve the underlying objectives that determines whether and how far the federal government itself may pursue them at all.

There is a significant difference between leaving room for the states to act even after the federal government has acted and questioning whether the federal government has sufficient warrant to intervene in the first place. The former places the allocation of regulatory authority between the federal government and the states squarely within Congress' unguided discretion; the latter obviously does not. The distinction also shapes the institutional role of the courts in policing the balance of legislative power. The doctrines of preemption and frustration of congressional purpose assume that the judicial function is to decide whether federal legislation has occupied the field, and they merely guide the courts in making that determination. The drafters of the Maastricht Treaty, however, were looking for tools of statutory limitation, not statutory construction. They therefore addressed the political branches directly, enjoining them to exercise self-restraint as subsidiarity defines it. At the same time, they left open the possibility that the Court of Justice would treat subsidiarity as a justiciable principle, ${ }^{370}$ and thus position itself to police the political branches directly.

\section{E. Subsidiarity and the Agencies}

The discussion thus far has revolved primarily around the traditional claim that institutional arrangements at the federal level in the United States guarantee due consideration for state interests, including the states' own capacity to accomplish the federal government's policy objectives. Such claims are most convincingly advanced with reference to Congress. The exercise of regulatory authority by the federal agencies, however, presents a rather different picture. The states are most definitely not represented as such in the composition of the agencies, nor do they represent in any meaningful sense the constituencies from which agency policymakers are drawn. If the federal agencies show institutional sensitivity to state interests, it must be for different reasons. ${ }^{371}$

370. See supra note 237 . As noted, the Maastricht Treaty does not declare subsidiarity to be a justiciable principle. But the European Council, expounding the subsidiarity doctrine after Maastricht, assumed that it would be justiciable, at least in direct actions in the Court of Justice. See supra notes 238-241 and accompanying text.

371. Partly at the urging of the National Governors' Association, however, federal agencies are increasingly structuring their rulemaking procedures in such a way that state and local governments are effectively heard in the development of federal regulationsnot only on the question of the necessity for federal action, but also on the administrative and financial costs that federal action imposes on the lower levels of government. See OMB, Annual Regulatory Program of the United States Government, 1987-1988, at 27 [hereinafter OMB, Regulatory Program, 1987-1988]. 
1. Subsidiarity as a Legislative Command to the Agencies. - Just as Congress has it within its power to legislate directly in the language or spirit of subsidiarity, it can also employ the language or spirit of subsidiarity in its delegations of legislative power to the agencies. If Congress does so clearly and concretely, it in effect makes subsidiarity one of the defining limitations on the powers conferred and a condition that the courts can conceivably enforce. Once again, there is little evidence that Congress regularly directs the agencies in terms expressly suggestive of subsidiarity. Congress seldom provides that, before issuing regulations, an agency must first satisfy itself that regulatory action at the state level would not adequately meet Congress' or the agency's purposes.

On the other hand, we have seen examples of federal statutes that safeguard the states' right to regulate private activity, subject to displacement by federal regulation should they fail to meet certain minimum congressional criteria. ${ }^{372}$ I depicted legislation of this kind as expressing subsidiarity by conditionally reserving standard-setting powers to the states. Almost invariably, Congress delegates to some federal agencythe EPA for example-key responsibilities for managing such statutory schemes of cooperative federalism. The agency typically issues regulations defining the basic statutory criteria; it reviews state standards or plans, if any, to see whether they satisfy those criteria; and it promulgates and enforces its own standards if a state elects not to establish a program or fails to establish an adequate one. It seems plain that subsidiarity is thereby made operationally part of the agency's statutory mandate.

The measure of standard-setting discretion that such schemes leave to the states ultimately depends of course on the rigor and precision of the minimum federal criteria. In Hodel $v$. Virginia Surface Mining $\mathcal{E}$ Reclamation Ass' $n,{ }^{373}$ for example, the plaintiffs complained that the Surface Mining Control and Reclamation Act permitted the Secretary of the Interior to promulgate federal surface mining standards that would leave the states no policymaking option other than to choose between enforcing the standards themselves and passing enforcement responsibilities on to the federal government. ${ }^{374}$ The Court nevertheless rejected the claim that the statute thereby unconstitutionally deprived the states of their regulatory authority:

A wealth of precedent attests to congressional authority to displace or pre-empt state laws regulating private activity affect-

372. See supra notes $317-329$ and accompanying text.

373. 452 U.S. 264 (1981).

374. The Court itself depicted the choice as follows:

[T] he States are not compelled to enforce the ... standards, to expend any state

funds, or to participate in the federal regulatory program in any manner whatsoever. If a State does not wish to submit a proposed permanent program that complies with the Act and implementing regulations, the full regulatory burden will be borne by the Federal Government.

Id. at 288. On this basis, the Court concluded that the Act did not "commandeer[] the legislative processes of the States." Id. 
ing interstate commerce when these laws conflict with federal law. Moreover, it is clear that the Commerce Clause empowers Congress to prohibit all-and not just inconsistent-state regulation of such activities. Although such congressional enactments obviously curtail or prohibit the States' prerogatives to make legislative choices respecting subjects the States may consider important, the Supremacy Clause permits no other result. ${ }^{375}$

This is a good reminder that, even under "cooperative" forms of federalism, the states enjoy policymaking freedom only within the limits that the competent federal agency chooses to establish.

2. Agency Authority to Preempt State Law. - In section D, ${ }^{376}$ I suggested that when Congress fails to deal explicitly with the issue of statutory preemption, the courts can indirectly advance the purposes of subsidiarity by erecting interpretive barriers to preemption. An analogous situation arises when Congress delegates regulatory authority to an agency without indicating whether the agency has the power to preempt state law. The extent of an agency's power is once again a matter of statutory interpretation, and whether the agency has exercised its power is a matter of agency intent. 377 The reported tendency of the courts is to allow agency preemption not only when Congress so states, but also when doing so will produce clear benefits, for example by eliminating state regulatory barriers to interstate trade, and when the effects of preemption are not unduly broad. ${ }^{378}$ If the reviewing court's role is basically to ensure that an agency's decision to occupy the field is a rational one, 379 then the agencies enjoy considerable latitude in deciding whether to do so. ${ }^{380}$ Like Congress itself, the agencies may implicitly preempt state law;

375. Id. at 290.

376. See supra notes $356-57$ and accompanying text.

377. See Capital Cities Cable, Inc. v. Crisp, 467 U.S. 691, 699 (1984); Fidelity Fed. Sav. \& Loan Ass'n v. De la Cuesta, 458 U.S. 141, 153-54 (1982); Ray v. Atlantic Richfield Co., 435 U.S. 151, 163-66, 170 (1978); United States v. Shimer, 367 U.S. 374, 381-83 (1961).

378. Early support for this view may be found in Paul R. Verkuil, Preemption of State Law by the Federal Trade Commission, 1976 Duke L.J. 225; see also Arkansas Elec. Power Coop. Corp. v. Arkansas Pub. Serv. Comm'n, 461 U.S. 375 (1983); American Optometric Ass'n v. FTC, 626 F.2d 896 (D.C. Cir. 1980).

379. See, e.g., Katherine Gibbs School, Inc. v. FTC, 612 F.2d 658 (2d Cir. 1979).

380. See generally Pierce, supra note 292, at 640 . To compensate for this latitude, Pierce specifically recommends that reviewing courts not only ensure that the states have adequate notice and opportunity to be heard before a preemptive rule is adopted, and that the preemptive effect of the rule is no broader than necessary, but also that "the agency's conclusion that the state regulation has the potential to create substantial disproportionate interstate spillovers is supported by substantial evidence and an adequate statement of reasons." Id. at 665 . For an example of judicial support of an agency decision to preempt state law under a statute that does not expressly empower the agency to do so, see Capital Cities Cable v. Crisp, 467 U.S. 691 (1984). See generally Zimmerman, supra note 190, at 81 (concluding the Supreme Court has permitted Congress broad discretion to preempt traditional state and local government functions, regardless of explicit statutory preemption provisions). Nonetheless, there is evidence that the courts may in fact require agencies to give an adequate statement of reasons before preempting state law. A court of 
the indicia of implied preemption do not differ markedly from those applicable to Congressional action. ${ }^{381}$ As I suggested in discussing statutory preemption, the doctrines of preemption and subsidiarity have different functions and different stakes. But if federal agencies are shown substantial deference when they leave no room for state regulation (i:e., when they preempt), they are also bound to be shown substantial deference when they do no more than decide that some federal agency action is warranted (i.e., when they simply legislate). The prospects of a subsidiarity review of such action are accordingly not very great.

3. Agency Self-Limitation. - Just as Congress may exercise legislative restraint though not required by the Constitution to do so, so the agencies may show regulatory restraint though not required by Congress to do so. Presumably they often do so, because of federalism concerns, a scarcity of agency resources, agency preferences in regulatory policy, or, more likely, some combination of these factors. Moreover, the exercise of federal regulatory power is distributed over a multitude of different agencies, each staffed and organized differently and operating under different procedures and different statutory mandates. No administrative law scholar to my knowledge claims to know what mode of reasoning and analysis on federalism issues is "standard" among agency regulators. A

appeals recently ruled that the Environmental Protection Agency failed to provide an adequately reasoned basis for departing from its past policies when it amended its National Contingency Plan for hazardous waste disposal to exclude the states from exercising any enforcement or remedy-selection authority under the Comprehensive Environmental Response, Compensation, and Liability Act of 1980 (CERCLA). See Ohio v. Environmental Protection Agency, 997 F.2d 1520, 1524 (D.C. Cir. 1993).

The U.S. Advisory Commission on Intergovernmental Relations has formally recommended that the standards for agency preemption of state law be tightened:

(3) The executive branch [shall] not preempt by administrative rulemaking unless Congress has expressly authorized such action and established clear guidelines for doing so, and unless the administrative agency taking such action clearly expresses its intent to preempt.

(4) The federal courts [shall] not confirm the validity of statutory and administrative preemptions unless accompanied by a clear statement of intent to preempt and unless the extent of preemption is no greater than necessary to give effect to that intent ....

ACIR Recommendations (March 1988), quoted in ACIR, Mixed Record, supra note 289, at 115; see also U.S. Advisory Comm'n on Intergovernmental Relations, Federal Statutory Preemption of State and Local Authority: History, Inventory, and Issues (Recommendations 1 through 3) 2, 11-13, 40-41 (1992). On partial preemption in particular, see Zimmerman, supra note 190, at 91-100 (defining and discussing several types of partial preemption).

As noted above, legislation pending before Congress would require an express statement of intent by Congress to preempt state law before a court could interpret a federal statute or regulation as in fact preemptive. See S. 480, supra note 365; H.R. 2327, supra note 365 .

381. See supra notes 362-365. For an example, see Hillsborough County, Fla. v. Automated Medical Labs., Inc., 471 U.S. 707, 714, 716 (1985) (agency preemption may be inferred from the pervasiveness of the agency's regulations or from the dominance of the federal interest in the area). 
vast amount of agency- and program-specific research would be needed before one could begin to describe a general working philosophy of regulatory federalism at the federal agency level.

Nevertheless, a large and influential body of opinion claims that federal agencies consistently err on the side of regulatory excess. ${ }^{382}$ Of course, not all forms of regulatory excess entail a disrespect for principles of federalism. An example is the allegedly heavy and unjustified burden of regulation on the private sector. Nevertheless, state and local governments do figure among the chief critics of federal regulatory excess, complaining about the implementation costs associated with stateadministered federal programs, ${ }^{383}$ paperwork requirements and other "red tape," 384 burdensome conditions on their entitlement to federal grants in aid, 385 "unfunded mandates," 386 and a variety of more specific

382. See Thomas O. McGarity, Regulatory Analysis and Regulatory Reform, 65 Tex. L. Rev. 1243 (1987); see also Robert E. Litan \& William D. Nordhaus, Reforming Federal Regulation 59 (1983); Michael Fix \& George C. Eads, The Prospects for Regulatory Reform: The Legacy of Reagan's First Term, 2 Yale J. on Reg. 293 (1985).

383. For a recent analysis of the direct implementation and compliance costs to state and local governments generated by federal regulations, see ACIR, Mixed Record, supra note 289, at 59-68. The U.S. Advisory Commission on Intergovernmental Relations places a conservative estimate of such costs at between $\$ 2.2$ billion and $\$ 3.6$ billion for 1990 , and at between $\$ 9$ billion and $\$ 12$ billion total for the years 1983 to 1990 .

384. See generally Gary Lee, Costly Federal Mandates Spur Protest: States, Counties Seek Relief from Programs Imposed Without Funding, Wash. Post, Oct. 27, 1993, at A3; see also Sending a Message to Washington, 40 Nat'l J. 2369, 2369 (1986).

385. See generally Rochelle L. Stanfield, What Has 500 Parts, Costs $\$ 83$ Billion and Is Condemned by Almost Everybody?, The Nat'l J., Jan. 3, 1981, at 4, 7; see also States and Cities Pay a High Price for Their Federal Aid, Heritage Found. Rep., July 15, 1986.

386. The term "unfunded mandates" refers to requirements imposed on state and local governments by federal law without coverage or reimbursement of the compliance costs. For a discussion of this phenomenon, see Zimmerman, supra note 190, at 152-58 (discussing the financial impact on state and local governments of federal mandates).

Unfunded mandates have recently been said to have reached such proportions as to constitute an overextension of the constitutionally delegated powers of the Congress and the Executive, an abridgment of the authority of citizens in their state and local communities to govern their own affairs, and an impairment of the ability of citizens to hold their elected federal officials accountable for the public costs of their decisions.

ACIR, Mixed Record, supra note 289, at 4. The U.S. Advisory Commission on Intergovernmental Relations has advocated a moratorium on the imposition of unfunded or underfunded mandates for at least two years while Congress and the Executive Branch conduct a thorough review of them. See id. The National Governors' Association's Permanent Policy on Federalism, reaffirmed and modified in 1993, specifically "calls [s] on members of Congress to oppose, and the President to veto, legislation that imposes further mandates without also providing adequate funding to cover the costs of implementation." NGA, supra note $303, \S 1.4 .4$. Meanwhile, the National Conference of State Legislatures publishes a "Hall of the States Mandates Monitor," or "Mandate Watch List," which tracks the progress of bills in Congress that would impose unfunded mandates on state and local governments.

Congress, as of this writing, is considering some twenty separate bills that seek to remedy the problem of unfunded mandates. The National Conference of State Legislatures has compiled and maintains a comprehensive inventory of such bills 
practices deemed objectionable. ${ }^{387}$ A particularly salient grievance of state and local governments over the recent past is the sharp decline in the availability of federal aid to help those governments to discharge their responsibilities. ${ }^{388}$

The principle of subsidiarity is in fact poorly adapted to the particular challenges to federal regulation now being mounted in state and local governmental circles in the United States. Subsidiarity expresses an elementary and abstract principle of regulatory power-sharing, one designed to reassure a polity experiencing sudden and dramatic centralization in the exercise of regulatory power. By contrast, regulatory patterns in the United States, although always subject to change, are well established, and a strong federal regulatory presence in the lives of Americans is not in itself something new. In some respects, state and local officials actually

("Comparative Analysis of Mandate Relief Bills in the 103d Congress"). Among the mechanisms that these various bills would introduce are: requirement of a General Accounting Office economic impact statement on all bills or resolutions reported by any committee (S. 81, H.R. 1088); provision for judicial review of federal agency compliance with regulatory flexibility analyses (S. 490, H.R. 830); improved or additional Congressional Budget Office estimates of state and local government compliance costs ( $S$. 563, S. 648, S. 993, H.R. 886, H.R. 894, H.R. 1006, H.R. 1295); requirement of an OMB report in conjunction with the President's budget proposal estimating the compliance costs to state and local governments of intergovernmental regulations for the coming two fiscal years (S. 1188); guarantee of appropriations to states to cover direct costs of federal mandates (S. 648, S. 993, S. 1188, H.R. 140, H.R. 369, H.R. 410, H.R. 894, H.R.J. Res. 254); a total prohibition on future unfunded federal mandates (H.R. Con. Res. 51); a requirement that no federal statute or rule issued under it shall preempt state or local law unless the federal statute explicitly states an intent to preempt or the conflict between the statute and state or local law is direct (S. 480, H.R. 2327); and imposition of an agency-byagency ceiling on the costs of regulation (S. 13).

387. The U.S. Advisory Commission on Intergovernmental Relations has identified four regulatory techniques as especially onerous on states and local governments:

(a) partial preemption (setting minimum national standards for the regulation of private activity, with implementation by the states permitted only to the extent that they meet those standards);

(b) direct orders (legal requirements imposed directly on State and local governments, enforceable through direct civil or criminal penalties);

(c) crossover sanctions (loss of financial assistance to certain State and local programs due to noncompliance with Federal requirements applicable to unrelated programs); and

(d) crosscutting requirements (the application of general federal legal requirements across the board to federal grants in order to advance national social or economic goals unrelated to the grants).

ACIR, Mixed Record, supra note 289, at 7. A non-programmatic objection voiced by state and local governments concerns the decline in federal funding in support of state administrative operations. See id. at 24.

388. See Rivlin, supra note 292, at 122-25; John Kincaid, Developments in FederalState Relations, 1990-91, in 29 The Book of the States 600, 602-07 (1992); John Kincaid, Book Review, 46 Nat'l Tax J. 245, 246-47 (1993) (reviewing Rivlin, supra note 292); see also David S. Broder, Frayed Federalism, Wash. Post, Aug. 15, 1993, at C7 (remarking that "[d]uring much of the past decade, the pattern of behavior in a national capital beset by rising deficits was to load more duties onto the states and localities-and send less money to pay for them"). 
prefer a strong federal presence. What they often seek is not so much a broad federal regulatory retreat of the sort conjured by subsidiarity as a series of specific operational remedies in the workings of federalism: greater flexibility in the administration of federal programs, less "red tape," fewer conditions on federal grants in aid, few if any "unfunded mandates," and much more generous federal financial support to state and local governments. Thus, although the leading organizations of state and local government are almost certainly sympathetic to subsidiarity as a general proposition, ${ }^{389}$ they have shown greater interest in targeting particular federal legislative and regulatory practices than in re-delineating federal and state spheres of authority as such. ${ }^{390}$

State and local governments claim, among other things, that they have insufficient access to regulatory decision-making and thus insufficient opportunities to combat the practices to which they more specifically object. Their advocates accordingly have advanced a variety of institutional reforms that would enable them to be more effectively heard in the regulatory process. For example, presidential policy at one time dictated that the federal departments and agencies consult with representatives of the chief executives of state and local government before developing or implementing programs directly affecting the conduct of state and local affairs. ${ }^{391}$ The practice was never vigorously pur-

389. The U.S. Advisory Commission on Intergovernmental Relations formulated recommendations as early as 1984 that closely track the principles of subsidiarity and proportionality, respectively:

[F]ederal intergovernmental regulation is warranted only when a clear and convincing case has demonstrated both the necessity of [federal] intervention and a marked inability of state and local governments to address the regulatory problem involved. In making this determination, the Commission strongly believes that ... the federal government [ ] [must consider its] responsibility to maintain the viability of the federal system and to respect the institutional integrity of states and their localities.

If, according to this test, the federal government's involvement in a regulatory program is appropriate, the Commission further recommends that the federal government choose the least intrusive means of intergovernmental regulation consistent with the national interest, allowing state and local governments the maximum degree of flexibility permissible.

ACIR, Regulatory Federalism, supra note 314, at 259 (Recommendation A.1).

390. Daniel Elazar believes that the United States has come to terms with its "somewhat chaotic existing system of intergovernmental sharing." Elazar, supra note 289, at 232. Accordingly, debate is less often over federalism as such than over devising the best ways to organize specific federal-state cooperative activities. See id. at 232-37. For a catalogue of leading strategies for reorganizing federal-state cooperation in the United States, see National Conference of State Legislatures, Official Policy on Federalism, supra note 289.

391. See Bureau of the Budget, Circular A-85 (June 28, 1967). Circular A-85 was based on a 1966 memorandum of President Johnson to the Director of the Bureau of the Budget (predecessor of the Office of Management and Budget) and to the heads of agencies. The memorandum on Consultation with Heads of State and Local Governments in Development of Federal Rules, Regulations, Standards, Procedures and Guidelines 
sued, ${ }^{392}$ and the order mandating it was subsequently rescinded. The rescission evidently grew not out of disenchantment with the concept, but rather out of a belief that the Executive's more general regulatory relief initiatives of the late 1970 s and early $1980 \mathrm{~s}^{393}$ had for all practical purposes eclipsed it. Despite occasional urgings ${ }^{394}$ and legislative initiatives $^{395}$ to this effect, no consultation requirement of this sort has since

(Nov. 11, 1966) is discussed in Elazar, supra note 289, at 168, and in ACIR, Regulatory Federalism, supra note 314, at 209-10.

Circular A-85 established procedures by which proposed agency rules having an intergovernmental impact were mandatorily submitted early in the process to the appropriate national association of state and local officials for review and comment. The circular made the U.S. Advisory Commission on Intergovernmental Relations responsible for seeing to it that agency proposals reached the appropriate bodies for review and that their reviews in turn reached the agencies.

Executive Order 12,612, discussed infra notes $425-443$ and accompanying text, requires executive branch agencies to consult with appropriate state officials and with organizations representing the states before imposing national standards in a regulatory area ordinarily subject to regulation by the states.

392. For a discussion of Circular A-85 and criticism of its effectiveness, see ACIR, Regulatory Federalism, supra note 314, at 209-10.

393. Circular A-85 was officially rescinded in 1978 with President Carter's issuance of a more general policy in the form of Executive Order 12,044. See infra note 401. In a memorandum to the heads of executive agencies accompanying Executive Order 12,044, President Carter recommended that certain national organizations representing state and local governments systematically review the semi-annual regulatory agendas that the Executive Order required the agencies to publish. The Order also required the agencies to communicate their concerns over the intergovernmental effects of a proposal to the responsible agency. Once in receipt of such a communication, the agency was required to develop a plan for consultation with state and local governments. See Memorandum from the President to Heads of Executive Departments and Agencies (Mar. 23, 1978), discussed in ACIR, Regulatory Federalism, supra note 314, at 211-12. Executive Order 12,044 was in turn replaced by President Reagan's Executive Order 12,291. See infra notes 404-420 and accompanying text.

394. See ACIR, Regulatory Federalism, supra note 314, at 211-14, 282, 286-87, 302-05, 310-12.

395. See, e.g., The Regulatory Reform Act of 1982, S. 1080, 97th Congress, 1st Sess. (1981). Had this bill been passed, section 3 would have amended the Administrative Procedure Act (APA) to require agencies engaged in rulemaking to request comments from state and local governments on the cost to those governments of any proposed rule. According to the Senate Report, the bill would have "require[d] special efforts by federal agencies to identify and analyze [these burdens] in order to better understand the effect of federal regulations on State and local governments." S. Rep. No. 305, 97th Cong., 1st Sess. 23 (1981). For "major" rules, as defined in the bill, section 4 of the Act would have made the burdens on state and local government an integral part of a statutorily required "regulatory analysis." See id. at 55, 127. The APA would also have been amended to require that agencies include in their statement of basis and purpose of a rule both an analysis of the alternative measures suggested by public comments received and a response to comments by state and local governments on the burdens likely to be imposed on them. See id. at 29. The Senate Report makes it clear that state and local regulatory mechanisms are among the alternatives that an agency would have to consider in its rulemaking. See id. at 50 .

S. 1080, section 8, would also have expressly amended the Federal Advisory Committee Act (FACA) to permit state and local officials and their representatives to meet 
been reinstituted. State and local governments accordingly must still depend on their own initiatives for access to the federal regulatory process. $^{396}$

A different but not inconsistent suggestion is that federal agencies be required by law to consider, among other factors, the effect of proposed rules on state and local governments, and where possible to select among regulatory alternatives the one that imposes the fewest burdens on those governments. Legislation currently before Congress would couple such an obligation with the requirement that every agency notice of proposed or final rule-making be accompanied by an "intergovernmental impact assessment." That assessment would estimate the rule's effect on the expenditure of state and local government resources and identify viable alternatives capable of accomplishing the same purposes while imposing fewer fiscal burdens on state and local governments. ${ }^{397}$ Significantly, such proposals ordinarily lay emphasis on the direct compliance costs that federal agency rules would impose on state and local governments; ${ }^{398}$ they generally leave aside, however, the less easily quantifiable federalism losses that federal agency rules can produce, namely the dimi-

with federal regulators without becoming subject to the requirements of FACA. See S. 1080 , supra, $\S 8$.

396. The U.S. Advisory Commission on Intergovernmental Relations accordingly has urged state and local governments to take precisely this initiative by "press[ing] for early access to the administrative rulemaking process." ACIR, Mixed Record, supra note 289, at 4 (Recommendation 2(a) (v)).

Organizations such as the National Conference of State Legislatures and the National Governors' Association are active in bringing their federalism concerns over proposed regulations to the attention of federal agency regulators. See, e.g., Letter from William T. Pound, Executive Director, National Conference of State Legislatures, to Mark Ragen, Assistant Secretary for Children and Families, U.S. Department of Health and Human Services (Aug. 5, 1991) (on file with the Columbia Law Review) (opposing proposed regulations on federal aid for child care on the ground that they establish standards that are too rigid and impose both unfunded mandates and excessive administrative burdens on the states). The letter cites Executive Order 12,612, discussed infra notes 425-443 and accompanying text, in support of its claim that provisions of the proposed rule "do not give sufficient credence to the states," and "limits [the] states' ability to decide the level of importance of health and safety regulations and parental choice." Letter, supra, at 3.

For a similar statement of position by the National Conference of State Legislatures (NCSL), in the form of an "Official Policy," rather than congressional testimony, see NCSL, Official Policy on Child Support Enforcement, objecting to "treating a weakness [in the enforcement of parental support obligations] by removing it to the federal government and funding, creating, and training a new bureaucracy at the national level." The Conference urges that federal efforts "be directed to helping states do a better job," chiefly through cooperation, training and financial aid. See id. at 3.

Agencies may of course systematically consult with their state and local government counterparts on a voluntary basis. In 1985, for example, the Environmental Protection Agency created a state-EPA consultation committee consisting of environmental officials from seventeen states. The committee was to meet four times a year. See ACIR, Mixed Record, supra note 289 , at 37 .

397. See The Fiscal Accountability and Intergovernmental Reform Act, H.R. 1295, supra note $305, \S \S 202-203$.

398. See id. $\$ 203$. 
nution in political authority of the states and local subdivisions and the concomitant losses in political accountability.

4. Presidential Restraints on Federal Regulation. - The perception of regulatory excess on the part of agencies has created a new set of opportunities for the U.S. Presidency. Although the Presidency is traditionally linked in political and symbolic terms to centralism rather than localism, over recent decades it has become more closely associated than any other branch of the federal government with the notion of regulatory federalism. The tendency began under the Nixon, ${ }^{399}$ Ford $^{400}$ and Carter administrations, ${ }^{401}$ with their emphases on governmental efficiency, antiinflation, cost-benefit analysis, and zero-base budgeting. Under the Reagan and Bush administrations, the tendency took a slightly different direction, toward returning powers previously exercised at the federal level to the states, to local governments, and to the private sector. More specifically, a series of executive orders instructed the federal agencies to channel their regulatory interventions in such a way as to show greater respect for certain economic and political values, among them federalism. ${ }^{402}$ Though not articulated in terms of any single overarching norm, the executive orders in question strongly evoke the European Community legal principles of proportionality and subsidiarity. Significantly, the

399. President Nixon's "Quality of Life Review" was the first systematic attempt by the Presidency to establish regulatory oversight of the agencies. It required the interagency exchange of information and views prior to an agency's adoption of any proposed or final rule on the environment, consumer protection or public health and safety. The process, coordinated by the Office of Management and Budget (OMB), sought to eliminate regulatory overlap and to resolve interagency disputes. See Morton Rosenberg, Regulatory Management at OMB, in Congressional Res. Serv., Library of Congress, prepared for the Senate Comm. on Governmental Affairs, 99th Cong., 2d Sess. (1986).

400. President Ford's Executive Order 11,821, 3 C.F.R. 926 (1971-1975), extended the regulatory review process to all executive agencies, but focused on the inflationary impact of federal rules. Prior to proposing "major" rules (as defined in the Order), agencies were required to prepare and submit to the Council on Wage and Price Stability (COWPS) an Inflationary Impact Statement. COWPS had no power to require changes to the proposed rules and OMB's powers were strictly managerial.

401. President Carter's Executive Order 12,044, 3 C.F.R. 154 (1979), required executive agencies to conduct a "regulatory analysis" of all "significant" rules before issuing them in proposal form. The analysis was meant to assess the rules' impact in terms of costs and benefits and to demonstrate the agencies' consideration of regulatory alternatives. The agencies also were required to prepare semi-annual agendas of their proposed rulemakings. The Regulatory Council (the heads of all executive agencies and departments and, on a voluntary basis, the independent regulatory agencies) collected and disseminated information about the agencies' proposals and constructed a semi-annual Regulatory Calendar whose purpose was to help coordinate regulation among the agencies. In addition, a Regulatory Analysis Review Group (RARG), consisting of representatives from the major regulatory agencies, chaired by the Chair of the Council of Economic Advisers, selected 10 to 20 proposed rules per year, chosen on account of their substantial economic impact, for independent review and comment prior to adoption. OMB's role was to provide guidance to the agencies on the conduct of regulatory analyses.

402. The principal Executive Orders-12,291, 12,372, and 12,612-are taken up below. See notes $404-455$ and accompanying text. 
proportionality aspects of the orders have consistently overshadowed their subsidiarity aspects. President Clinton's September 1993 Executive Order on regulatory planning and review, ${ }^{403}$ which largely replaces its predecessors, continues that emphasis.

a. Executive Order 12,291 and Proportionality. - Perhaps the best known of these instruments is Executive Order 12,291, issued under the Reagan administration. ${ }^{404}$ Although it has since been repealed, many of its features are carried forward in the 1993 Executive Order of President Clinton that replaces it. Executive Order 12,291 called upon the executive branch agencies, when "promulgating new regulations, reviewing existing regulations, and developing legislative proposals concerning regulation," to observe certain general regulatory principles. ${ }^{405}$ Besides ensuring that they had adequate information justifying the need for a proposed measure and assessing its consequences, ${ }^{406}$ and that they set regulatory objectives so as to maximize the net benefits to society ${ }^{407}$ and reflect overall regulatory priorities, ${ }^{408}$ the agencies were also required to satisfy themselves that the action's "potential benefits to society . . . outweigh [ed] ... the potential costs to society," 409 and that the action chosen entailed, as compared to alternative ways of achieving regulatory objectives, "the least net cost to society." 410

Where a proposed rule was a "major" one, as defined in the Executive Order, ${ }^{411}$ the agency was required to perform a "Regulatory Impact Analysis," which described the rule's costs and benefits (monetary and non-monetary alike), determined its net benefits, and identified "alternative approaches that could substantially achieve the same regulatory goal at lower cost," estimating their respective costs and benefits and giving any legal reason why they could not be adopted. ${ }^{412}$ When required by the Executive Order to conduct a regulatory impact analysis, an agency was also required to submit the analysis to the Director of the Executive Branch's Office of Management and Budget (OMB) for review according to a prescribed timetable. ${ }^{413}$ The OMB Director had, within further time limits, the right to demand a consultation with the agency and to require the agency to refrain from publishing the analysis or the proposed or final rule until OMB had completed its review and the agency had considered and responded to OMB's views. ${ }^{414}$ The agency was required to in-

403. See infra note 456 and accompanying text.

404. Exec. Order No. 12,291, 3 C.F.R. 127 (1981).

405. Id. § 2.

406. See id. § 2(a).

407. See id. $\$ 2(c)$.

408. See id. § $2(\mathrm{e})$.

409. Id. § 2(b).

410. Id. $\S 2(d)$.

411. See id. §1(b).

412. See id. § 3(d)(1)-(4).

413. See id. § $3(\mathrm{e})$.

414. See id. $\S 3$ (f) (1). 
clude OMB's views on a proposed rule, and the agency's own response to those views, in the rule-making file. ${ }^{415}$ The Executive Order also required agencies to review all existing rules under the Order's standards and, in the case of major rules, to conduct regulatory impact analyses. The OMB Director could actually designate specific existing rules for review and set a schedule for such review or for the conduct of an impact analysis. ${ }^{416}$

In requiring that executive agency measures survive cost-benefit scrutiny and constitute the least drastic means, the Executive Order imposed all the essential aspects of the European legal doctrine of proportionality. In further requiring that agencies actually perform cost-benefit analyses and assess and compare regulatory alternatives, the Order also imposed on the agencies significant procedural obligations. The obligations were greatest in the case of major rules, which became subject to formal regulatory impact analyses and OMB review. But, although far-reaching in its substantive and procedural demands, Executive Order 12,291 did not establish any significant system of sanctions. An agency's failure to respect the standards set out in the Order or to conduct the analyses required of it did not, in the words of the Order, "create any right or benefit, substantive or procedural, enforceable at law by a party against the United States, its agencies, its officers or any person." 417 A failure thus did not constitute grounds for judicial review of the resulting rule. Even the $\mathrm{OMB}$, and indirectly the President, lacked formal sanctions against the agencies for their failure to respect the terms of the Order, although their political leverage over the agencies is of course vast. ${ }^{418}$ The Order itself provided that "[n]othing in [it] shall be construed as displacing the agencies' responsibilities delegated by law."419

415. See id. § 3(f)(2).

416. See id. §3(i).

417. Id. $\S 9$.

418. Among the OMB's sources of leverage are its control over agency budgets and staffing levels, its right to disapprove an agency's programs of information collection, and its power to clear agency requests for new legislation. Moreover, OMB's power under Executive Order 12,291 to delay the proposal or adoption of rules (conceivably indefinitely) pending its own review was itself a significant sanction over an agency eager to finish a piece of regulatory business. See Joseph Cooper \& William F. West, Presidential Power and Republican Government: The Theory and Practice of OMB Review of Agency Rules, 50 J. Pol. 864, 874, 876 (1988).

419. Exec. Order No. 12,291, supra note 404.

Subsequently, Executive Order 12,498 measurably strengthened Executive Order 12,291 in its restraint of the agencies by requiring them to prepare annual agendas of their ongoing and projected rulemaking activities for the year, to demonstrate their conformity with the administration's regulatory principles and, most important, to secure OMB approval of any agenda item before undertaking rulemaking activities with respect to it. See Exec. Order No. 12,498, 50 Fed. Reg. 1036 (1985). Executive Order 12,498 was designed to identify unnecessary federal interventions at an early enough stage to avoid the investment of resources normally made, and the raised expectations normally created, by the time a proposed rule has already been formulated. The Order thus sought to avert regulatory faits accomplis. See OMB, Regulatory Program, 1987-1988, supra note 371, at 
Still, Executive Order 12,291 was not chiefly concerned with federalism; regulatory rationality was its focus. Even viewed from a constitutional perspective, the Order's separation of powers implications have far overshadowed its federalism implications. ${ }^{420}$ Nevertheless, any instrument that requires greater discipline by the federal government in its regulatory initiatives indirectly promotes localism, for it leaves the field correspondingly more open to regulation (or non-regulation) by state and local government. Whether and to what extent state and local officials seize the opportunity to regulate depends, of course, on the economic and political criteria by which they, as decision-makers, approach the regulatory process at their levels. But the choice remains theirs.

b. Executive Order 12,372 and Federalism. - An executive order that more directly expresses the federalism dimension of agency regulation, but still stops well short of prescribing subsidiarity, is Executive Order 12,372, also issued under the Reagan administration.421 This Order, which remains unrepealed, attempts, in its words, "to foster an intergovernmental partnership and a strengthened federalism."422 However, its scope of application is narrow; it addresses only the question of whether and to what extent federal agencies should rely on state and local governments to review proposed federal assistance programs and to coordinate them. The Order requires federal agencies to provide opportunities for consultation with state and local officials whose governments would contribute funds or would otherwise be directly affected by the proposed federal funding. It also requires agencies to utilize any available procedures under state law for reviewing and coordinating federal assistance programs. The states are encouraged to substitute their own plans for federally required state plans "[whenever] State planning and budgeting systems are sufficient," and they are entitled to "simplify" the ordinary federal requirements for state plan submissions. ${ }^{423}$ Finally, federal agencies must attempt to "accommodate" concerns that state and local officials express about proposed federal assistance and, when they cannot accommodate those concerns, must explain why. ${ }^{424}$ However, although Executive Order 12,372 clearly has the flavor of subsidiarity, it relates

xiii. Executive Order 12,498 in effect gave OMB a veto over the agency's individual regulatory agenda items, which is more than Executive Order 12,291 gave OMB over proposed or final rules. A regulatory action omitted from the approved Regulatory Program, or materially different from the one described in the Program, could not (subject to certain narrow exceptions) be undertaken without OMB's express approval. As in the case of other Executive Orders that empower OMB, disputes between OMB and an executive agency could be brought to the President for resolution.

Executive Order 12,498 was, along with Executive Order 12,291, repealed in September 1993 by President Clinton, and replaced with a new comprehensive Executive Order on regulatory planning and review, No. 12,866. See infra note 456.

420. See generally Cooper \& West, supra note 418.

421. Exec. Order No. 12,372, 3 C.F.R. 197 (1982 Comp.).

422. Id. preamble.

423. See id. § 2(d).

424. See id. $\S 2$ (c). 
solely to the federal government's programs of financial assistance and, even then, to their administrative aspects only.

c. Executive Order 12,612 and Subsidiarity. - It is President Bush's Executive Order 12,612, ${ }^{425}$ entitled "Federalism," that most directly addresses the issue of subsidiarity. Although President Clinton's 1993 Executive Order does not by its terms repeal this Order, it does not in any real sense reaffirm it either. Moreover, because Executive Order 12,612426 was consistently viewed in practice as subordinate to Executive Order 12,291 and practically subsumed under it, as we shall see, the latter's repeal casts doubt on Executive Order 12,612's continuing validity. The Order's close affinity to subsidiarity nevertheless justifies its examination in this Article.

According to its preamble, Executive Order 12,612 is designed "to restore the division of governmental responsibilities between the national government and the States ... and to ensure that the principles of federalism established by the Framers guide the Executive departments and agencies in the formulation and implementation of policies." 427 It applies to all policies having "federalism implications," which are defined as measures "that have substantial direct effects on the States, on the relationship between the national government and the States, or on the distribution of power and responsibilities among the various levels of government." 428 Section 2 of the Order recites the fundamental principles that should guide the agencies in formulating or implementing policies having federalism implications. In doing so, it links federalism to political liberty, ${ }^{429}$ self-determination, ${ }^{430}$ and

425. Exec. Order No. 12,612, 3 C.F.R. 252 (1987). The Order grew out of a recommendation by a federal interagency task force ("The Working Group on Federalism") created in 1985 by President Reagan's Domestic Policy Council.

426. See infra notes $447-454$ and accompanying text.

427. Exec. Order No. 12,612, supra note 425, preamble. The Office of Management and Budget, which has chief responsibility for implementing Executive Order 12,612, expressed the idea behind the Order as follows:

Government works best when decisionmaking responsibilities are placed at the lowest possible level. Important decisions affecting people should be made by those closest to the problem. Moreover, responsiveness to local preferences and conditions is best assured by providing local institutions with authority and responsibility for action.

OMB, Regulatory Program 1988-1989, supra note 287, at 26. More specifically, OMB cites a "tendency of [the] Federal government . . . to ignore or disregard State law in the accomplishment of a Federal objective." Id. at 30.

428. Exec. Order No. 12,612, supra note $425, \S 1$ (a). "States" is defined as "States of the United States of America, individually or collectively, and, where relevant, . . . State governments, including units of local government and other political subdivisions established by the States." Id. $\S 1$ (b).

429. See id. $\$ 2$ (a). Federalism is claimed to promote political liberty by limiting the size and scope of the national government.

430. The people of the States are claimed by the Order to be basically free "to define the moral, political, and legal character of their lives." Id. \$2(d). Federal authorities are accordingly urged to encourage "individuals, families, neighborhoods, local governments, 
diversity ${ }^{431}$ - values also claimed to support the principle of subsidiarity in the European Community-while specifically reaffirming the Tenth Amendment and the enumeration of powers. ${ }^{432}$ The Order expresses with particular clarity a preference for local governance: "In most areas of governmental concern, the States uniquely possess the constitutional authority, the resources, and the competence to discern the sentiments of the people and to govern accordingly." 433 Thus, "[i]n the absence of clear constitutional or statutory authority, the presumption of sovereignty should rest with the individual States." 434

Executive Order 12,612 draws a distinction between "problems of national scope" and "problems that are merely common to the States." 435 While the former presumably justify federal action, the latter do not, "because individual States, acting individually or together, can effectively deal with them." ${ }^{436}$ In other words, even when constitutionally and statutorily empowered to accomplish a particular objective, federal authorities are urged to do so only if the states, acting alone or collectively, cannot effectively accomplish the objective themselves. The Order further directs federal authorities to "closely examine the constitutional and statutory authority supporting any Federal action that would limit the policymaking discretion of the States, and should carefully assess the necessity for [any] such action" 437 and to "[e]ncourage [the] States to develop their own policies to achieve program objectives." 438 Finally, the Order requires the agencies to " $[\mathrm{r}]$ efrain, to the maximum extent possible, from establishing uniform, national standards for programs and, when possible, defer to the States to establish standards." 439 The elements of subsidiarity are pervasive in this Order.

and private associations to achieve their personal, social and economic objectives through cooperative effort." Id. § 2(h).

431. "The nature of our constitutional system encourages a healthy diversity in the public policies adopted by the people of the several States according to their own conditions, needs, and desires [and leaves] individual States and communities . . . free to experiment with a variety of approaches to public issues." Id. § 2(f).

432. See id. § 2(b), (c), (g). For the text of the Tenth Amendment, see supra note 139.

433. Id. § 2(e).

434. Id. § 2(i). Moreover, " $[u]$ ncertainties regarding the legitimate authority of the national government should be resolved against regulation at the national level." Id.

435. Id. $\S 3(\mathrm{~b})(1)$.

436. Id.

437. Id. $\S 3(a)$. The Order adds that, where practicable, the States should be consulted before any such action is taken, presumably in part to help in assessing the "necessity" of federal action. When action within the federal sphere would limit the "policymaking discretion" of the States, it should be undertaken only if "national activity is necessitated by the presence of a problem of national scope." Id. § 3(b).

438. Id. $\$ 3(\mathrm{~d})(1)$. The Order also addresses state administration of federal law. Federal authorities are told to "grant the States the maximum administrative discretion possible." Id. $\S 3(c)$.

439. Id. $\S 3(d)(2)$. When national standards are nonetheless required, agencies are told to consult with appropriate state officials in developing them. Id. $\S 3(d)$ (3). 
Like Executive Order 12,291, Executive Order 12,612 also imposes procedural obligations on the executive branch agencies. For each proposal having "sufficient federalism implications," 440 an agency must prepare a "Federalism Assessment," which basically certifies that the agency evaluated the proposal in terms of the criteria set out in the Executive Order. Moreover, the Assessment must specifically identify (1) any aspect of the proposal that is inconsistent with those criteria, (2) the costs or burdens that it would impose on the states, and (3) the effect on state sovereignty, including the states' ability to perform their traditional governmental functions. ${ }^{441}$ The Federalism Assessment must accompany any submission relating to the policy that the agency makes to OMB under Executive Order 12,291, and the agency head must in any event take the Assessment into account when deciding whether or how to adopt and implement the policy. ${ }^{442}$ Again like Executive Order 12,291, Executive Order 12,612 claims to leave ultimate responsibility for regulatory decisions in the agencies' own hands, and OMB accordingly may not as such prevent an agency from adopting a rule or regulation. Nor is an agency's violation of the Executive Order subject to judicial review. The Order, by its terms, "is intended only to improve the internal management of the Executive branch [and not] to create any right or benefit ... enforceable at law."443

d. The Executive Orders in Practice. - The Executive Orders mandate legislative analyses that, despite their scientific ring, are highly subjective. ${ }^{444}$ The agencies have vast discretion in collecting and evaluating data, in identifying and weighing relevant arguments, and in balancing arguments against one another. The resources for conducting such anal-

Executive Order 12,612 does not by its terms address the question of federal agency preemption of state law. It is clear from the tenor of the Order, however, that agency preemption is disfavored. This particular point was actually made explicit in a Report by the Presidential Task Force on Regulatory Relief (Aug. 11, 1983), setting out ten general guidelines to the agencies for implementing Executive Order 12,291. According to one of the guidelines, “[f] ederal regulations should not preempt State laws or regulations, except to guarantee rights of national citizenship or to avoid significant burdens on interstate commerce." The Report is discussed in OMB, Regulatory Program, 1987-1988, supra note 371 , at $16-23$.

440. Exec. Order No. 12,612, supra note 425, § 6(b). Each executive department and agency is supposed to appoint an official responsible for ensuring implementation of the Executive Order and, more particularly, for determining which proposed policies have sufficient federalism implications to warrant preparation of a Federalism Assessment. See id. $\$ \S 6(a), 6(b)$.

441. See id. $\S 6(c)$. The reference to "traditional state governmental functions" is an allusion to National League of Cities v. Usery, 426 U.S. 833 (1976), overruled by Garcia v. San Antonio Metro. Transit Auth., 469 U.S. 528 (1985). See supra notes 334-340 and accompanying text.

442. See Exec. Order No. 12,612, supra note 425, $\$ \$ 6(\mathrm{~b}), 6(\mathrm{c})$.

443. Id. $\S 8$.

444. "Cost-benefit analysis is not an exact science; instead, its conclusions typically rest on a variety of more or less discretionary judgments." Cooper \& West, supra note 418 , at 878. 
yses being limited, the agencies naturally concentrate those resources on the proposals about which they care the most or about which they entertain the greatest technical or political doubts. In the end, the analyses call heavily for the raw exercise of judgment. Much the same can be said of OMB's review of agency analyses, except that the political component in OMB's review is probably even more pronounced. The political proximity of OMB to the Office of the President means, among other things, that the values and interests identified by the President as particularly worth advancing in regulatory decision-making are likely to be given the greatest consideration in OMB's review. Like the analyses themselves, the reviews can also be conducted with a greater or lesser degree of scrutiny.

Precisely because the exercises themselves are so highly political, it is difficult to assess them objectively. Moreover, the only comprehensive data we have on them come from OMB itself. 445 Relying on those data, most commentators conclude that the requirement of regulatory impact analyses under Executive Order 12,291 has had significant results, particularly regarding those policies of greatest concern to the President and his "key constituencies." 446 Gauging the efficacy of Executive Order

445. Since 1981, OMB has published annual reports listing every agency rule returned by $\mathrm{OMB}$ to an agency for further consideration, or modified or withdrawn as a result of OMB review under Executive Order 12,291. OMB has also, pursuant to Executive Order 12,498, supra note 419, published an Annual Regulatory Program of the United States Government, beginning with the year April 1, 1985-March 31, 1986.

OMB reported in its 1986-1987 Program that, of the rules reviewed in that period, OMB approved $68.3 \%$. $22.9 \%$ were modified by the agency following OMB review, $2.8 \%$ were withdrawn by the agency, and $1.4 \%$ were simply returned to the agency for reconsideration as inconsistent with the Administration's regulatory policy. (The remaining $4.5 \%$ were either found to be exempt from review or returned to the agency on formal grounds.) As of the end of $1986, \mathrm{OMB}$ had reviewed a total of 5,900 proposed rules and 8,200 final rules under Executive Order 12,291. See OMB, Regulatory Program, 1987-1988, supra note 371 .

OMB also interprets the apparent decline since 1981 in the number of rules proposed annually, and the reduction in their scope and ambitiousness, as evidence of OMB influence. (OMB reported that in 1986 the number of pages in the Federal Register declined to the lowest level since 1974). See id. at 626-27. Overall, OMB claims that Executive Order 12,291 has "held the number of new rules to the minimum necessary,... revised ill-conceived ones, ... and imposed long needed discipline on the rulemaking process." Hearings before the Governmental Affairs Subcommittee, 1986, at 227. For further favorable evaluation by OMB of its own review efforts, see OMB, Regulatory Program, 1987-88, supra note 371 , at xlix.

446. As Cooper and West note:

In general, E.O. 12291 has been an effective means of identifying, evaluating, and influencing those agency policies most important to the president and his key constituencies. It is true, of course, that oversight has not been comprehensive, given the small size of [the OMB] staff ... and the large number of rules submitted for review each year. . . Yet the Reagan order has evoked a diffuse but effective set of mechanisms for bringing especially significant and/or politically troublesome rules to the attention of administration officials .... . Typically OMB has been able to achieve its key policy goals through a combination of pressure and delay. 
12,612 is considerably more difficult, since $\mathrm{OMB}$ has no separate data on the Federalism Assessments required by that Order or on their effects upon agency rule-making patterns. ${ }^{447}$ In the only published critique of Executive Order 12,612, the U.S. Advisory Commission on Intergovernmental Relations judged the program rather harshly. The Commission concluded that agencies varied widely in their apparent compliance with the Order's requirement of a Federalism Assessment, and that some failed utterly to implement it. With respect to the assessments themselves, the Commission found many to be shallow and conclusory, as if performed pro forma. ${ }^{448}$ As required by Executive Order 12,498, each regulatory initiative included in the annual U.S. Government Regulatory Program must now contain a section heading captioned "Need for Federal Solution." 449 This is an apparent response to Executive Order 12,612's requirement that agencies demonstrate the need for federal, as opposed to state and local, government action. Typical statements of "need" include the following:

Tort liability and workers' compensation requirements, which vary considerably from State to State, only serve as partial incentives to provide the necessary safety and health training for supervisory personnel. 450

Cooper \& West, supra note 418 , at 77. Cooper and West thus conclude that the OMB statistics show the Executive Orders, particularly 12,291, to have been very effective. They cite the significant number of rules disapproved by $O M B$ and modified accordingly, the importance of those particular rules, and the trend over time toward greater rates of disapproval and modification. They also argue, but of course cannot easily prove, that the Orders have an effect by way of anticipation. In other words, the agencies arguably formulate and adopt rules with the prospect of $O M B$ review and objections in mind. See id. at 875-76.

A report by Congress' Legislative Research Service concludes as follows: 'Taken together, Executive Orders 12291 and 12498 provide the President, through OMB, with a formidable apparatus to significantly influence, if not effectively control, regulatory decisionmaking of covered agencies at all stages of the rule formulation and development process." Rosenberg, supra note 399, at 210.

The U.S. Advisory Commission on Intergovernmental Relations is much less positive in its assessment of the Orders. "President Reagan's election, the creation of the Presidential Task Force on Regulatory Relief, and the new rulemaking procedures associated with Executive Order 12291 did not alter the fundamental dynamics of the policymaking process." ACIR, Mixed Record, supra note 289, at 27.

447. $\mathrm{OMB}$ also has issued no guidelines to the agencies concerning their performance of Federalism Assessments.

448. "[T] he executive order requirements are commonly given perfunctory treatment by federal regulatory agencies." ACIR, Mixed Record, supra note 289, at 35 .

449. The other regular section headings for each initiative in the annual regulatory program are "Problem to Be Solved," "Approach," "Changes in Policy and Timing," "Currently Projected Costs and Benefits," "Next Steps," and "Agency Contact."

450. Executive Office of the President, Regulatory Program of the United States Government 1992-1993, at 344. 
In the absence of national . . standards for direct dischargers, permitting authorities develop limitations for discharging facilities on a case-by-case basis. ${ }^{451}$

This rulemaking will provide the necessary criteria for personal fall-protection equipment (which currently do not exist) and will negate the need for these criteria to be repeated numerous times throughout the general-industry standards when such equipment is required. ${ }^{452}$

In fact, the overwhelming majority of agency statements of "Need for Federal Solution" make no reference whatsoever to the efficacy or potential efficacy of options implemented at the state and local government levels; they do not even acknowledge that such options might exist. ${ }^{453}$ Impact analyses of any sort run the risk that they will be conducted cursorily and yield routine results, and Federalism Assessments have evidently proven to be no exception. As for OMB's performance, the Advisory Commission found that it had devoted too few resources to overseeing the agencies' compliance with the Order and that it in any case lacked effective sanctions against non-complying agencies. In the Commission's overall judgment, Executive Order 12,612 "failed to produce the significant changes in federal agency decision-making expected by most state and local government officials." 454

That the Executive Order has a highly checkered implementation record does not of course mean that it is conceptually flawed or even that it did no good. At least some agency officials claim that the Order caused them to focus on federalism issues when they otherwise might not have done so. ${ }^{455}$ The Order thus may well have raised federal regulators' consciousness of the desirability of allowing the states to address problems that lie within their jurisdiction and that they have the capacity to solve satisfactorily. The Advisory Commission appears to believe that more determined supervision by OMB of the agencies' performance under the Order might have made a significant difference. However, it did not, and perhaps could not, substantiate that claim.

e. Clinton Executive Order 12,866 on Regulatory Review. - Each new President in recent times has treated the executive order as a means of expressing his own preoccupations in the area of regulatory policy, and President Clinton is no exception. A new Executive Order 12,866 on

451. Id. at 608 .

452. Id. at 372.

453. An example of a Federalism Assessment that is silent about regulatory alternatives at the state and local level is the following: "The problem of head injuries due to vehicle interior contacts is fairly large. Injury reductions are possible if structures capable of cushioning head impacts in crashes are developed. A variety of factors, including the belief that certain modifications may not have consumer appeal, prevent manufacturers from readily making safety improvements without Federal regulation." Id. at 385.

454. ACIR, Mixed Record, supra note 289, at 2.

455. See id. at 33 (the Order "changed the nature of internal debate"). 
Regulatory Planning and Review ${ }^{456}$ echoes many of the themes of the orders that preceded it. ${ }^{457}$ One of these themes, though by no means the most salient among them, is federalism. ${ }^{458}$ In this connection, the Order for the first time not only requires that $\mathrm{OMB}$ meet regularly with state and local government representatives to facilitate regulatory review, ${ }^{459}$ but also requires agencies themselves to seek the involvement of state and local governments before proposing new rules likely to impose burdens on them. ${ }^{460}$ Significantly, however, the Order emphasizes the financial and administrative impact of federal regulation on state and local governments, ${ }^{461}$ and not the adverse effect of such regulations on those governments' policymaking freedom. ${ }^{462}$ In other words, subsidiarity does not figure significantly as a principle of governance in the new presidential framework of regulatory review. Executive Order 12,612, which had largely embodied the subsidiarity idea, is neither repealed nor affirmed. That Executive Order 12,866 is plainly comprehensive and expressly re-

456. Exec. Order No. 12,866, 58 Fed. Reg. 51,735 (1993). For an informal account of the new Order, see John F. Cooney, Regulatory Review in the Clinton Administration, Admin. L. News, Fall 1993, at 1.

457. The heart of the Order, as of its predecessors, is the mandatory conduct of agency cost-benefit analyses, OMB review of such analyses, the mandatory preference for the least burdensome regulatory alternatives (assuming some form of regulation is in fact necessary), and an agency-by-agency regulatory agenda. Newer elements in the Order include the requirement of openness and accessibility in the regulatory review process, the creation of opportunities for consultation in the planning mechanism, a systematic review of existing regulations, and the commitment of principal oversight authority to the Vice President. See Exec. Order No. 12,866, supra note 456.

458. "The American people deserve ... regulatory approaches that respect the role of State [and] local ... governments." Id. preamble.

459. See id. $\S 4$ (e) (requiring quarterly meetings "to identify both existing and proposed regulations that may uniquely or significantly affect those governmental entities"). State and local governments are also specifically encouraged to assist OMB in identifying existing regulations that impose significant or unique burdens on them and that may no longer be justified. See id. $\$ 5$ (b).

460. See id. $\S 6$ (a)(1).

461. Section 1 (b) (9) reads:

Wherever feasible, agencies shall seek views of appropriate State, local, and tribal officials before imposing regulatory requirements that might significantly or uniquely affect those governmental entities. Each agency shall assess the effects of Federal regulations on State, local, and tribal governments, including specifically the availability of resources to carry out those mandates, and seek to minimize those burdens that uniquely or significantly affect such governmental entities, consistent with achieving regulatory objectives.

Id. $\S 1(\mathrm{~b})(9)$.

462. However, section 6 (a) (3) (B) (ii) requires agencies to provide OMB, in the case of all significant proposed rules, with an assessment of how the proposal "avoids undue interference with State, local, and tribal governments in the exercise of their governmental functions." Id. \& 6 (a) (3)(B) (ii). It remains to be seen not only how serious this assessment will have to be, but also whether the notion of "undue interference" will include erosion of state and local government policymaking freedom. 
pealed the most significant executive orders that preceded it, ${ }^{463}$ while ignoring both Executive Order 12,612 and its content, is only further evidence that Executive Order 12,612 has not played a major role up to now in U.S. regulatory review. It signals that subsidiarity may not play much of a role in regularity review under the Clinton administration either.

\section{F. Conclusion.}

Despite its evident preoccupation with federalism, the United States has shown rather little use for a specific doctrine of subsidiarity. ${ }^{464}$ Apart from Executive Order 12,612 and the surrounding rhetoric, the United States has not made subsidiarity the measure of federalism. Looking for subsidiarity in the interstices of U.S. federalism is thus more than a little frustrating. To the extent that the Supreme Court has placed the Tenth Amendment at the service of federalism, it has thought in terms of a categorical "core of State sovereignty" that Congress may not invade. That "core" has been defined as the states' right to organize themselves freely in the performance of their functions, ${ }^{465}$ or as their right not to be conscripted in the enforcement of federal law. ${ }^{466}$ But never has it been translated into an express and judicially enforceable statement of preference for state over federal action in areas of concurrent jurisdiction. A strong body of opinion would continue to deny the Tenth Amendment judicial sanction altogether, on the theory that, by its composition and its procedures, Congress naturally protects the states anyway, and that if it does not, the states have only themselves to blame. One can speculate over the sincerity of this faith in the political process; it is equally possible, however, that the dogma simply masks a collective unwillingness to incur the institutional and conceptual costs of taking subsidiarity seriously.

Though not itself legally constrained by a principle of subsidiarity, Congress has it well within its power to structure its own practices so as to lay greater emphasis on the capacity of the states to meet Congress' objectives. Thus far it has not done so. Congress can also restrain the exercise of authority by federal agencies through a statutory requirement of subsidiarity. The fact is, however, that congressional enactments only occasionally contain language requiring the agencies to conduct their regulation in conformity with anything like subsidiarity. This may be due to Congress' own sense of freedom from any such constraint, and possibly

463. See Exec. Order No. 12,291, supra note 404; Exec. Order No. 12,498, supra note 419.

464. Justice Antonin Scalia has observed that subsidiarity is not a "principle of law" in the United States, but at most "a desideratum of policy." (Emphasis omitted). He finds that, even as a mere "aspiration rather than a legal rule," subsidiarity "deserve[s] a place alongside such other unquestionably true and indubitably unhelpful propositions as 'do good and avoid evil' and 'buy low and sell high.'" Scalia, supra note 295.

465. See National League of Cities v. Usery, 426 U.S. 833, 852 (1976), overruled by Garcia v. San Antonio Metro. Transit Auth., 469 U.S. 528 (1985).

466. See New York v. United States, 112 S. Ct. 2408, 2428 (1992). 
also to its habit of passing legislation that, for all its conditions and limitations, nevertheless places the emphasis on "enabling" the agencies to solve freely a problem that Congress may have managed to identify in only the most general of terms. Finally, judicial policies toward federal preemption at both the legislative and agency levels, while unquestionably reasonable, furnish subsidiarity with only weak support at best. Preemption doctrines by their nature are incapable of more.

The Presidency of the United States, on the other hand, has attempted to fill the breach with respect to subsidiarity at the federal agency level. Executive orders now seek to channel the exercise of federal regulatory discretion in ways that uncannily track what the Europeans call proportionality and subsidiarity. However the effort, at least with respect to enforcement of Executive Order 12,612 on Federalism, appears to have been half-hearted, as if in recognition that a bare and abstract principle of subsidiarity is not a finely-enough tuned corrective to the complex problems of contemporary U.S. federalism. Executive Order 12,612 itself thus seems never to have been vigorously enforced and it is unclear whether it has even survived President Clinton's reform of the regulatory review process.

This is not to suggest that organizations that speak for the interests of state and local government as such in the United States have never subscribed to a general principle of federalism along the lines of subsidiarity; in fact they have, especially recently. ${ }^{467}$ Even in those quarters, however, the notion that the purposes of federalism will be served by systematically favoring state over federal initiatives still tends to take a back seat to more pragmatic concerns over such issues as the fiscal and administrative costs of federal regulation to state and local governments. ${ }^{468}$

\section{EC Subsidiarity and U.S. Federalism}

The elevation of subsidiarity to a first principle of Community constitutional law contrasts sharply with the apparent indifference to subsidiarity both as an abstract tenet and a working instrument of U.S. federalism. There is, of course, no necessity that the constitutional design of the emerging European Union mirror either the normative or the operational features of the United States. The point of the comparison is plainly enough not to have the United States join the subsidiarity bandwagon-far from it; it is, rather, to ask whether the tepid embrace of subsidiarity in U.S. federalism signals that subsidiarity has indeed been oversold in the Community, and if not, why not. If subsidiarity is not equal to federalism's task in the United States, it is certainly fair to ask why it should be considered fit for those purposes in Europe. The com-

467. See supra notes $315,382-398$ and accompanying text.

468. See supra notes 383-398 and accompanying text. See generally Zimmerman, supra note 190, at 15-16 (comparing states' favorable response to Reagan-era shift away from federal regulation to states' fiscal objections to the same). 
parison, in short, may help us assess the virtues of subsidiarity for the Community and, in the process, may allow us to better understand the respective natures of EC and U.S. federalism.

I approach this task by first seeking to explain why the United States, although it takes federalism seriously, behaves as if it can afford to take subsidiarity rather lightly. The comparison with the United States helps clarify the basic distinction, already sketched in Part III, between the concepts of subsidiarity and federalism. Reexamining institutional relationships within the Community in light of the United States situation and experience, I conclude that the Community does not have the same luxury of indifference toward subsidiarity. The comparison also reinforces my conclusions that the political institutions of the Community should rigorously practice the principle of subsidiarity, much as I envisioned them doing in Part II of this Article, however difficult that may be, and that the Court of Justice should undertake the delicate policing functions that I also described there.

\section{A. The U.S. and EC Settings}

Any comparison between the United States and the Community today must of course acknowledge the fundamental difference between, on the one hand, maintaining a semblance of balance in the power relations between the federal government and the states in a system designed along federal lines from its very beginning, and, on the other hand, consciously imposing a new multi-layered legal system on a continent historically dominated by sovereign Nation-States, themselves mostly unitary in structure. The mere fact that the United States has endured as a federal system over as long a period as it has, on the basis of a largely stable set of federalism ground rules, has afforded it a sense of both continuity and security. That sense of continuity and security in turn helps to explain the reluctance to designate any single legislative principle, be it subsidiarity or anything else, as the watchword of federalism, or to ask the judiciary to enforce that principle against the political branches.

The escalating debates over regulatory federalism in the United States tell us that at least some participants in the U.S. political process, and some observers, consider this sense of continuity and security to be basically false. Their claim, in sum, is that while the United States has maintained its fidelity to federalism in form, it has abandoned it in substance. It is of course possible to define federalism in purely formal terms, and the more strictly one does so, the more continuity one tends to see. Most would agree, however, that at some point a formally federal system may experience so great a distortion in the balance of power that it ceases to be genuinely federal. Measuring federalism substantively, however, is a very difficult thing to do, if only because we lack accepted criteria for doing so.

It is interesting that, while critics in the United States commonly allege and deplore a growing imbalance of power between the federal gov- 
ernment and the states, to the detriment of the states, the means of redress that they most vigorously advance are ones that sidestep the central issue raised by subsidiarity. We have seen that the most common prescriptions include a reduction in the detail of federal legislation and regulation, an increase in flexibility in the choice of means by which state and local governments carry out federal policies, an abandonment of particularly objectionable federal legislative techniques, and, above all, the provision of full federal funding to the states for implementing programs that are essentially imposed on them from above. It is tempting to explain away the difference between the debates in the United States and Europe in terms of a supposed American penchant for the pragmatic and particularized and an aversion to the abstract. The fact is that, quite apart from any such real or imagined differences in approach, the advocates of federalism in the United States may simply be more concerned with the specifics of the relationship between the federal government and the states than with the relative scale on which those governments exercise political power. This in turn may reflect an assumption that, while certain patterns or techniques of federal governance are especially objectionable to state and local governments, and should be avoided, the American system of federalism nevertheless tolerates, and has survived, a wide range of differences in the distribution of policymaking authority between the federal government and the states.

A further factor shaping the qualitative difference between U.S. and EC federalism relates to the political and cultural stakes in the integration process. While regional differences in the United States are not to be underestimated, it is idle to suppose that geography as such plays nearly as big a role in federalism debates in the United States today as it does in Europe. In Europe, geography still brings along with it differences in culture, language, and social and political values that are far more pronounced than the generally prevailing differences in the United States. These differences obtain not only among Member States, but also among regions within them. Because the reservation of political authority to more local units, at the expense of the federal government, brings greater opportunities for the assertion of distinctive cultural, linguistic, and social and political values, subsidiarity is a particularly apt instrument for a polity determined not merely to maintain a decent equilibrium in power between the federal government and the states, but to minimize the loss of political autonomy at the more local levels.

\section{B. Subsidiarity and Federalism Revisited}

For these and doubtless other reasons, U.S. federalism places greater emphasis on the presence of an overall balance of power between the federal government and the states than on respect for any single rule for allocating competences among the different levels of government. Federal and state-level decision-making each have at least some natural advantages that nearly all would concede and that Congress and the federal 
agencies have often sought to combine in creative ways. Beneath the well-worn generalities about the virtues of centralism and localism lies a recognition that the choice of the governmental level at which a given problem is best addressed, or a given policy best established, should in principle turn on a number of different considerations. The European Community doctrine of subsidiarity certainly points to one such consideration-the relative capacities of federal and state government to deal effectively or adequately with the problem or policy at hand. We have of course seen that the notion of dealing "effectively" or "adequately" with an issue depends entirely on the criteria by which we measure effectiveness or adequacy, 469 and the way in which those criteria are applied. Nevertheless, subsidiarity does usefully focus our attention on the sufficiency of the means that are available at the different levels of government.

However, one may, in assigning political authority in a democratic society, legitimately ask other, perhaps more focused, questions. One may ask, for example, whose interests are likely to be affected by a given policy, and seek to vest the power to establish that policy in the body that most effectively represents those interests. It is likewise fitting, in a market that would be "common," to inquire into the importance on any given issue of having a common regulatory standard, and to set that value off against the value of allowing standards on that particular issue to be set locally. (Some matters may strike us as of "naturally" local interest; others may not, but a wide disparity in local needs or conditions might nevertheless argue in favor of local governance.) Economists remind us to look also at the risk that communities may regulate in ways that impose costs unfairly on neighboring communities or on their populations, that they will engage in destructive competition in an effort to attract and keep industry, or that they may fail to capture important economies of scale. 470 Conversely, governance at the state or local level may be a way to ensure, if we deem it appropriate to do so, that communities bear the burdens of remedying a problem that they may have had a unique hand in causing. Even an essentially non-economic factor like diversity, often assumed invariably to favor localism, may be reexamined in the context of the problem at hand to see how much it really matters in a particular setting. As the range of considerations deemed relevant to the allocation of power

469. See supra note 225.

470. See generally Edmund W. Kitch, Regulation and the American Common Market in Regulation, Federalism and Interstate Commerce 9, 12-13 (A. Dan Tarlock ed., 1981). For an extended discussion of a federalism formula based on the "spillover" effects of state regulation on other states, see Pierce, supra note 292 , at 646-61. OMB acknowledges that severe negative spillover from state regulation of an exclusively local problem may justify federal intervention:

At the same time, Federal regulation may be justified, even when the object of regulation is exclusively local, if the benefits of regulation are primarily local but the costs fall disproportionately on citizens of other States. In such cases States have incentives to be too restrictive.

OMB, Regulatory Program, 1988-1989, supra note 287, at 21. 
among levels of government widens, the number of criteria and the incidence of conflict among them inevitably increase. It is no wonder that discussions of federalism in the United States so rarely produce general outcome-decisive formulas. ${ }^{471}$

Subsidiarity, on the other hand, entails approaching federalism with the distinctive attitude that federal action should be taken in areas of shared competence only if the goal in question cannot adequately be achieved by action at the state level or below. Unless the term "adequately" is, as seems quite possible, simply a cover for something else (including the specific factors I have mentioned above, but possibly others as well), the choice between state and federal action under the principle of subsidiarity could turn on some diffuse assessment of whether action at the state level will satisfactorily meet the purposes that seem chiefly to underlie a proposed course of action. In other words, subsidiarity could displace a variety of specific considerations that are actually highly pertinent to choosing the most appropriate level of government for action. In a seasoned federalism like that of the United States, accustomed to taking this variety of considerations into account, the notion of subsidiarity may, in the end, have a somewhat hollow, even foolish, ring to it.

The analytic difference between subsidiarity and federalism can perhaps best be appreciated by returning to the problem of squaring subsidiarity with federal regulation of interstate commerce. If, due to subsidiarity, we foreclose federal regulation of an activity on the ground that the states can adequately regulate it, while wholly disregarding the indirect effects of disparate state regulations on the functioning of a common market, we run the risk of causing substantial harm to interstate commerce. Prevailing attitudes toward federalism in the United States avert this risk because they allow the political branches, if they choose to do so, to entertain the tradeoff squarely. The Office of Management and Budget summarizes the exercise as deciding "whether the burdens on interstate commerce arising from divergent State and local regulations are so great that they outweigh the advantages of diversity and local political choice." 472

The difference between subsidiarity, as the Community understands it, and federalism, as commonly understood in this country, is therefore . not simply one of emphasis. As expressed in the Maastricht Treaty, subsidiarity states a generic preference for state over federal action when either would in some generalized sense do. Put differently, subsidiarity

471. For an attempt to consider the full range of relevant considerations, and still develop presumptions in favor of either state or federal regulation according to the type of regulation involved, see Susan Bartlett Foote, Beyond the Politics of Federalism: An Alternative Model, 1 Yale J. on Reg. 217 (1984).

472. OMB, Regulatory Program, 1988-1989, supra note 287, at 21. According to $\mathrm{OMB}$, however, a mere linkage to interstate commerce is insufficient to overcome the preference for state action: "It is not a sufficient case for Federal regulation that the object of regulation is part of interstate commerce." Id. 
systematically places the burden of proof on the proponents of Community action. ${ }^{473}$ How strong this preference for state action turns out to be will ultimately depend on what it takes and, especially, how much it takes to establish the states' inadequacy in this regard. My purpose in contrasting the notion of subsidiarity with federalism is not to discredit it, but merely to highlight its evident bias. It is to show that an equation of subsidiarity with federalism (an equation that Executive Order 12,612 in the United States, for example, explicitly invites us to draw) is misleading and possibly false.

\section{The Political Safeguards of Federalism and "Commandeering" in the Community}

Any comparison between the United States and the European Community with respect to subsidiarity must of course also consider the institutional arrangements within those communities. As we have seen in an earlier part, ${ }^{474}$ the theory that governmental structures at the federal level adequately safeguard federalism translates much less well to the European Community context than one might suppose. The Council of Ministers seems initially the perfect example of a lawmaking institution whose "composition and selection" (to borrow Wechsler's term) ${ }^{475}$ give effect to the constituent states' interests in self-governance. Nevertheless, I have sought to show why, notwithstanding its structure and mode of operation, the Council has failed of late to reassure its national and local constituencies that it is adequately looking after their distinct interests, much less protecting their distinctive qualities. ${ }^{476}$ In fact, the basic notion that the Council of Ministers directly represents the peoples of Europe has never been seriously advanced, even by the Community's strongest advocates.

The Council's unique structure thus forces recognition of the distinction between representing the states and representing the people that Congress (at least since the direct election of U.S. Senators) has managed to obscure. The Council represents, and claims to represent, only the states themselves; even then, as we have seen, ${ }^{477}$ the states' interests on any given legislative occasion may have little to do with the aspirations of its subcommunities and its population for self-governance and all else that the subsidiarity concept evokes. The Council simply has sufficient incentives and opportunities-including a strong sense of Community "mission" and a relative insulation from the ordinary national mecha-

473. See Making Sense, supra note 21, at 2-6.

474. See supra notes $256-274$ and accompanying text.

475. Wechsler, supra note 288 , at 451 . "[T] he national political process in the United States-and especially the role of the state in the composition and selection of the central government-is intrinsically well adapted to retarding or restraining new intrusions by the center on the domain of the states." See id. at 543.

476. See supra notes 262-267 and accompanying text.

477. See supra notes 259-261 and accompanying text. 
nisms of accountability, to name just two-to offset any natural calling to protect the Member States' interests and to help preserve their identities and the identities of their various subcommunities.

As for the Commission, its structure and composition offer even less by way of protection of the states and their subcommunities' decisional autonomy. ${ }^{478}$ In the absence of a chief executive elected popularly by a Community-wide constituency, the Community's greatest institutional hope for securing the virtues of subsidiarity may be the European Parliament. But that body's own structural features, ${ }^{479}$ coupled with its curtailed decisional powers, ${ }^{480}$ mean that it too offers only tenuous support for the notion that the Community institutions inherently safeguard subsidiarity. The fact is that, under any theory that looks to the political process at the federal level to safeguard federalism, a democratic deficit necessarily implies a federalism deficit as well.

The direct institutional relations between the Community and the Member States also differ substantially from those that obtain in U.S. federalism, and they too argue in favor of taking subsidiarity especially seriously. From its beginnings, the Community has relied pervasively on the Member State legislatures, executives, and courts for the enforcement of Community law, ${ }^{481}$ and this is unlikely to change in the near future. One consequence of this arrangement-and there are of course others ${ }^{482}$-is that the resources of all the branches of government in the Member States, and thus the resources of their populations, are harnessed, albeit nonexclusively, to the implementation of policy that has effectively been made in Brussels, at an altogether different level of government. Moreover, as we have seen, the makers of that policy are neither politically accountable in any verifiable way to the people of those states, nor necessarily even politically representative of them. This "accountability deficit" is all the more pronounced where the Member States are themselves divided among culturally or linguistically distinctive subcommunities that are even further removed from the Community decisional process than the national constituencies that the Member States purport to represent.

What we observe in the workings of the Community is thus the very pattern of intergovernmental relations-specifically, commandeering of Member State apparatus and resources in the service of federally-established policies-that has generated constitutional disquiet in the United States in recent years. ${ }^{483}$ To the extent that a disjunction between the

478. See supra note 268 and accompanying text.

479. See supra notes $269-271$ and accompanying text.

480. See supra notes $272-273$ and accompanying text.

481. See supra note 275 and accompanying text.

482. Another such result is that the efficacy of Community law in Europe continues to depend on the efficacy of Member State administrations and courts.

483. See supra notes $345-351$ and accompanying text. For a comparison between the attitudes toward commandeering in the United States and the Community, see James E. Pfander, Permissible Directives in Europe and Unlawful Conscriptions in the United States 
freedom to make policy and the burdens of implementing it compromises democratic values, the European Community finds itself in a very precarious situation indeed. Subsidiarity has a special calling in the Community precisely because it may help reduce the field over which this unavoidable disjunction occurs.

\section{Conclusion}

The European Community (or more broadly after Maastricht, the European Union) ${ }^{484}$ is basically a young federal system still in search of enduring constitutional foundations. Memories easily reach back to a period when the Community did not exist, or existed but was barely taken seriously as a legal and political force on a landscape of traditional nation-state sovereignty. Precisely because the Community institutions have come so far so fast in securing their place in European governance, they have awakened intense fears in the Member States, their subcommunities, and their populations over a loss of control of their political future.

In Part I of this Article, I sought to demonstrate that the Community institutions have very largely behaved, at least since 1985 , as if the mere prospect of strengthening the commonness of the internal market justified establishing Community-wide standards in business and trade even in otherwise purely intrastate situations. I also sought to show how, despite the impressive arsenal of doctrinal limits on Community action, a political decision to regulate a matter on a Community-wide basis was unlikely to be questioned by the Court of Justice. More recently, the institutions have shown their readiness to regulate in essentially non-economic spheres as well. Traditionally they have offered an economic (typically an internal market) rationale for doing so, bolstered by reference to the doctrine of implied powers. More commonly today, they invoke an express grant of authority in the Treaty to regulate non-economic matters-initially certain aspects of social policy and workers' rights, later environmental protection and worker safety, and since the entry into force of the Maastricht Treaty, still others. Once again, the Court of Justice has shown little enthusiasm, and rightly so, for restraining the exercise of political judgment by the institutions. It has preferred to question an institution's choice of treaty article (and therefore voting procedures) on which to base its interventions, rather than to question the scope or substance of the interventions themselves. The conditions in the Community are thus decidedly ripe for the kind of federal legislative selfdiscipline that subsidiarity implies.

(forthcoming 1994). Pfander predicts increasing disquiet in Europe over the use of directives as a source of unfunded mandates. See id. at 81 .

484. See supra note 8 . 
To maintain that subsidiarity "fits" the European Community at its present juncture is not to ignore its shortcomings. ${ }^{485}$ As I have argued in Part II, subsidiarity is immensely difficult to operationalize, particularly if the legislative process is at the same time to pay due regard to proportionality as a governing value; a realistic view of the interplay between subsidiarity and proportionality suggests that tradeoffs of an irreducibly political character will be involved. This in turn means that, justiciable though it may be, subsidiarity will not easily be judicially enforced. As I sought to show in Part III, subsidiarity even on its own terms seems quite crude, certainly as compared to prevailing attitudes toward federalism in the United States. A salient feature of United States federalism is its capacity to accommodate a wide assortment of considerations in the decision to allocate political responsibility over a given issue to a certain level of government. Another feature is its close attention to the operational aspects of federalism, be they unfunded mandates, red tape, or statutory forms of cooperative federalism designed to allocate decisional authority in very precise ways between the federal government and the states. As against this combination of breadth in identifying the factors relevant to federalism, on the one hand, and attentiveness to specificity in the workings of federalism, on the other, the European Community's absorption with subsidiarity may appear to be immature. However, for a polity that is still seeking to establish its basic federal-state equilibrium, rather than merely to preserve it, the search for a guiding principle of regulatory federalism, and the designation of subsidiarity as that principle, are entirely appropriate.

485. See Koopmans, supra note 275, at 1050 (arguing that "the important thing is probably not to abolish States or to replace old States by new States, but to devise levels of coordinate government"). 